\title{
The Antiepileptic Potential of Nucleosides
}

\author{
Z. Kovács*,1, K.A. Kékesi ${ }^{2,3}$, G. Juhász ${ }^{2}$ and Á. Dobolyi ${ }^{4,5}$
}

${ }^{I}$ Department of Zoology, University of West Hungary, Savaria Campus, Szombathely, Hungary; ${ }^{2}$ Laboratory of Proteomics, Institute of Biology, Eötvös Loránd University, Budapest, Hungary; ${ }^{3}$ Department of Physiology and Neurobiology, Eötvös Loránd University, Budapest, Hungary; ${ }^{4}$ Semmelweis University and the Hungarian Academy of Sciences, Department of Anatomy, Histology and Embryology, Neuromorphological and Neuroendocrine Research Laboratory Budapest, Hungary; ${ }^{5}$ Laboratory of Molecular and Systems Neuroscience, Institute of Biology, Eötvös Loránd University and the Hungarian Academy of Sciences, Budapest, Hungary

\begin{abstract}
Despite newly developed antiepileptic drugs to suppress epileptic symptoms, approximately one third of patients remain drug refractory. Consequently, there is an urgent need to develop more effective therapeutic approaches to treat epilepsy. A great deal of evidence suggests that endogenous nucleosides, such as adenosine (Ado), guanosine (Guo), inosine (Ino) and uridine (Urd), participate in the regulation of pathomechanisms of epilepsy. Adenosine and its analogues, together with non-adenosine (non-Ado) nucleosides (e.g., Guo, Ino and Urd), have shown antiseizure activity. Adenosine kinase (ADK) inhibitors, Ado uptake inhibitors and Ado-releasing implants also have beneficial effects on epileptic seizures. These results suggest that nucleosides and their analogues, in addition to other modulators of the nucleoside system, could provide a new opportunity for the treatment of different types of epilepsies. Therefore, the aim of this review article is to summarize our present knowledge about the nucleoside system as a promising target in the treatment of epilepsy.
\end{abstract}

Keywords: Epilepsy treatment, nucleosides.

\section{INTRODUCTION}

Epilepsy is a neurological disorder characterized by chronically recurrent seizures [1-3]. It may also be associated with neurobehavioral comorbidities (e.g., impaired cognitive functions, abnormal social behavior and increased risk of psychiatric disorders) [4]. Various types of brain illnesses, such as central nervous system (CNS) infections, traumatic brain injury, stroke and febrile seizures, can induce processes that may lead to the generation of an epileptic brain (epileptogenesis) [3]. As one of the cellular mechanisms of epileptogenesis [3], the excessive discharge of highly synchronized and hyperexcitable neurons in different brain areas, including the cerebral cortex, hippocampus and several subcortical structures, may induce different types of epileptic seizures [5-7]. Excessive excitatory neurotransmission (e.g., via the glutamatergic system) and/or a decrease in inhibitory neurotransmission (e.g., via the GABAergic system) may disrupt the excitatory/inhibitory balance, which may excite or exacerbate epileptic seizures [5-8].

Approximately 50 million people suffer from epilepsy worldwide and approximately $30 \%$ of patients are drug refractory [9]. This refractory state is possibly due to seizureinduced adaptive mechanisms, such as overexpression of the P-glycoprotein and the multidrug-resistance-associated protein [10-12]. Although the pathomechanisms (mechanisms of pathological processes) of different types of epilepsies

\footnotetext{
*Address correspondence to this author at the Department of Zoology, University of West Hungary, Savaria Campus, Szombathely, Károlyi Gáspár tér 4., 9700 Hungary; Tel: 0036 94/504 409; Fax: 0036 94/504 404;

E-mail: zskovacs@ttk.nyme.hu
}

have been elucidated $[1-7,13-18]$, epilepsy treatment is mainly based on the suppression of symptoms by antiepileptic drugs $[19,20]$, which have severe adverse effects [21, 22]. Consequently, there is an urgent need to develop new therapeutic approaches to find safer and more effective antiepileptic strategies to prevent and cure epilepsy.

Nucleosides, such as adenosine (Ado), guanosine (Guo), inosine (Ino) and uridine (Urd), participate in the synthesis of DNA and RNA and are involved in gene transcription, the storage and conversion of energy and the regulation of physiological and pathophysiological processes in the brain (e.g., sleep, memory, Parkinson's disease, psychiatric disorders and epilepsy) [23-34]. In addition, genetic disorders of purine or pyrimidine metabolism may be associated with different diseases [35-38]. De novo synthesis of nucleosides is limited in the adult brain [39]. Therefore, nucleoside transport into the brain via the blood-brain barrier and a salvage mechanism supply brain cells with nucleosides [40, 41]. The nucleosides may be metabolized intracellularly or extracellularly (Fig. 1) [40-42] and transported via the nucleoside transporters expressed in brain cells (Table 1) [40, $41,43]$. There is considerable evidence for neuromodulatory functions of nucleosides. Adenosine and Guo can be released from synaptosomes [44-49] and may then bind to their specific receptors $[32,50,51]$; thus, Ado, Guo and most likely Urd [52] may be signaling molecules (neuromodulators or neurotransmitters) in the brain. Area-, age- and genderdependence of nucleoside levels and/or nucleoside metabolism, nucleoside transporters and nucleoside receptors in the brain have been described previously, suggesting that nucleosides have different physiological and pathophysiological 


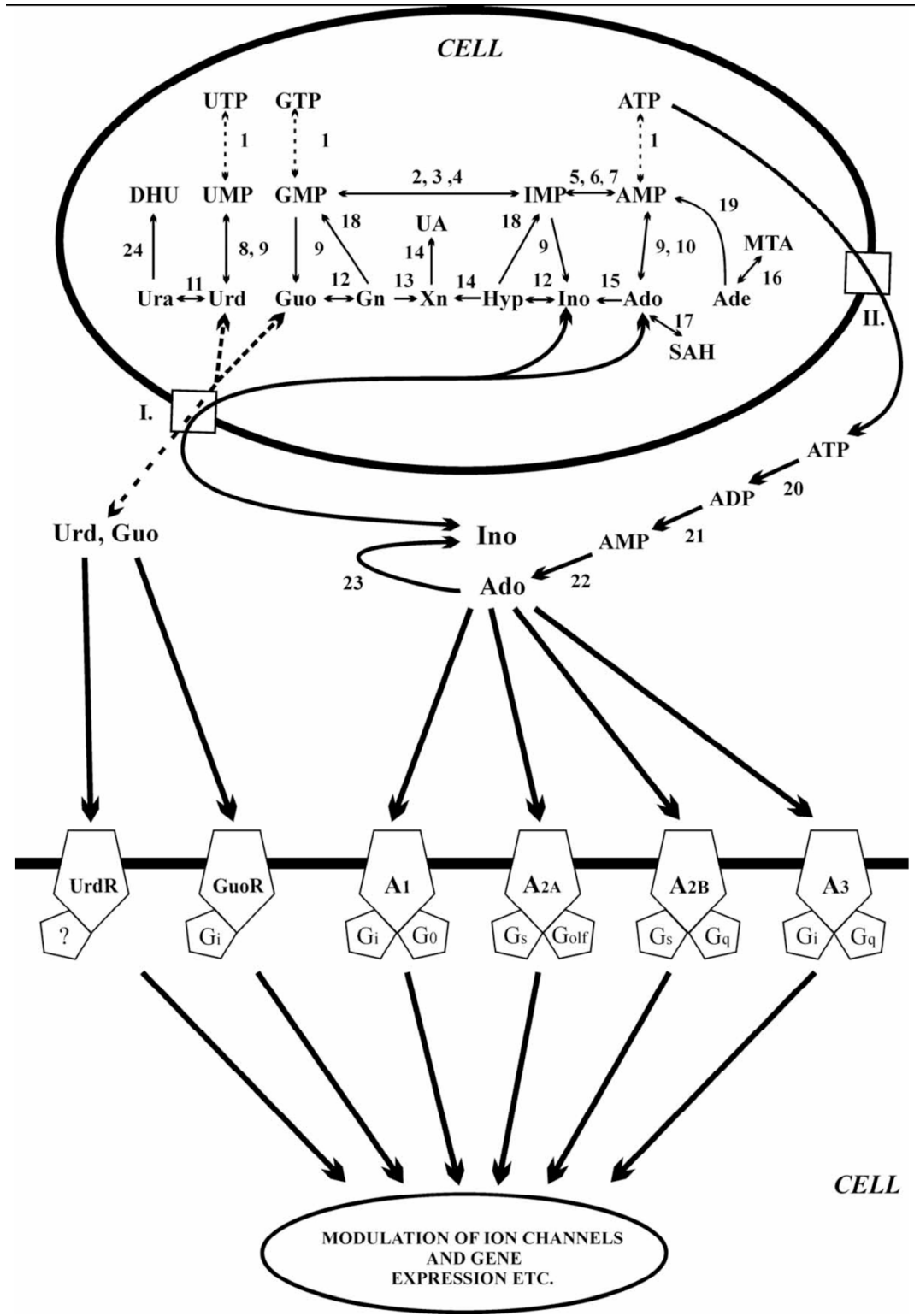

Fig. (1). Pathways of nucleoside metabolism, nucleoside transport and signal transduction mechanisms of nucleoside receptors. Abbreviations: I: nucleoside transporters; II: ATP channels and transporters; 1: nucleoside mono- and diphosphate kinases and nucleoside di- and triphosphate phosphatases; 2: GMPR, GMP reductase; 3: GMPS, GMP synthetase; 4: IMPDH, IMP dehydrogenase; 5: AMPDA, AMP deaminase; 6: ASL, adenylosuccinate lyase; 7: ASS, adenylosuccinate synthetase; 8: UCK, uridine-cytidine kinase; 9: 5'NT, 5'-nucleotidase $(\mathrm{cN})$; 10: ADK, adenosine kinase; 11: UP, uridine phosphorylase; 12: PNP, purine nucleoside phosphorylase; 13: GDA, guanine deaminase; 14: XO, xanthine oxidase; 15: ADA, adenosine deaminase; 16: MTAP, 5'-deoxy-5'-methylthioadenosine phosphorylase; 17: SAHH, adenosylhomocysteinase; 18: HGPRT, hypoxanthine phosphoribosyltransferase (hypoxanthine-guanine phosphoribosyltransferase); 19: APRT, adenine phosphoribosyltransferase; 20: ecto-ATPase; 21: ecto-ADPase; 22: ecto-5'NT, ecto-5'-nucleotidase (eN); 23: ecto-ADA, ectoadenosine deaminase; 24: $\mathrm{DPD}$, dihydropyrimidine dehydrogenase; $\mathrm{A}_{1}, \mathrm{~A}_{2 \mathrm{~A}}, \mathrm{~A}_{2 \mathrm{~B}}$ and $\mathrm{A}_{3}$ : different subtypes of adenosine receptors; Ade: adenine; Ado: adenosine; ADP, adenosine diphosphate; AMP: adenosine monophosphate; ATP: adenosine triphosphate; DHU: dihydrouracil; $\mathrm{G}_{\mathrm{i}}, \mathrm{G}_{0}, \mathrm{G}_{\mathrm{s}}, \mathrm{G}_{\mathrm{q}}, \mathrm{G}_{\mathrm{olf}}$ : G-proteins $\left(\mathrm{G}_{\mathrm{i}}\right.$ : inhibitory, $\mathrm{G}_{\mathrm{s}}$ : stimulatory and so on); GMP: guanosine monophosphate; Gn: guanine; GTP: guanosine triphosphate; Guo: guanosine; GuoR: Guo receptor; Hyp: hypoxanthine; IMP: inosine monophosphate; Ino: inosine; MTA: 5'-deoxy-5'methylthioadenosine; SAH: S-adenosylhomocysteine; UA: uric acid; UMP: uridine monophosphate; Ura: uracil; Urd: uridine; UrdR: Urd receptor; UTP: uridine triphosphate; Xn: xanthine.

roles in different brain areas and that these roles may be modulated by age and gender [30, 31, 53-57]. Among their diverse neuromodulatory functions, nucleosides may have a role in the modulation of epileptic activity as well [27, 33, 58-69]. Therefore, drugs or nucleoside derivatives effective on nucleoside uptake, nucleoside receptors or nucleoside metabolism may be useful for the treatment of different dis- eases in the CNS, such as epilepsy [31]. Adenosine kinase (ADK) inhibitors, Ado uptake inhibitors and Ado-releasing implants have also been shown to be effective in treating epileptic seizures [27, 32, 65, 67]. In addition, not only Ado but also non-Ado nucleosides (e.g., Guo, Ino and Urd) showed antiseizure/anticonvulsant activity in various epilepsy models and are potential candidates involved in 
Table 1. Selectivity of the Nucleoside Transporters and Signaling Mechanisms of Ado Receptors in the CNS

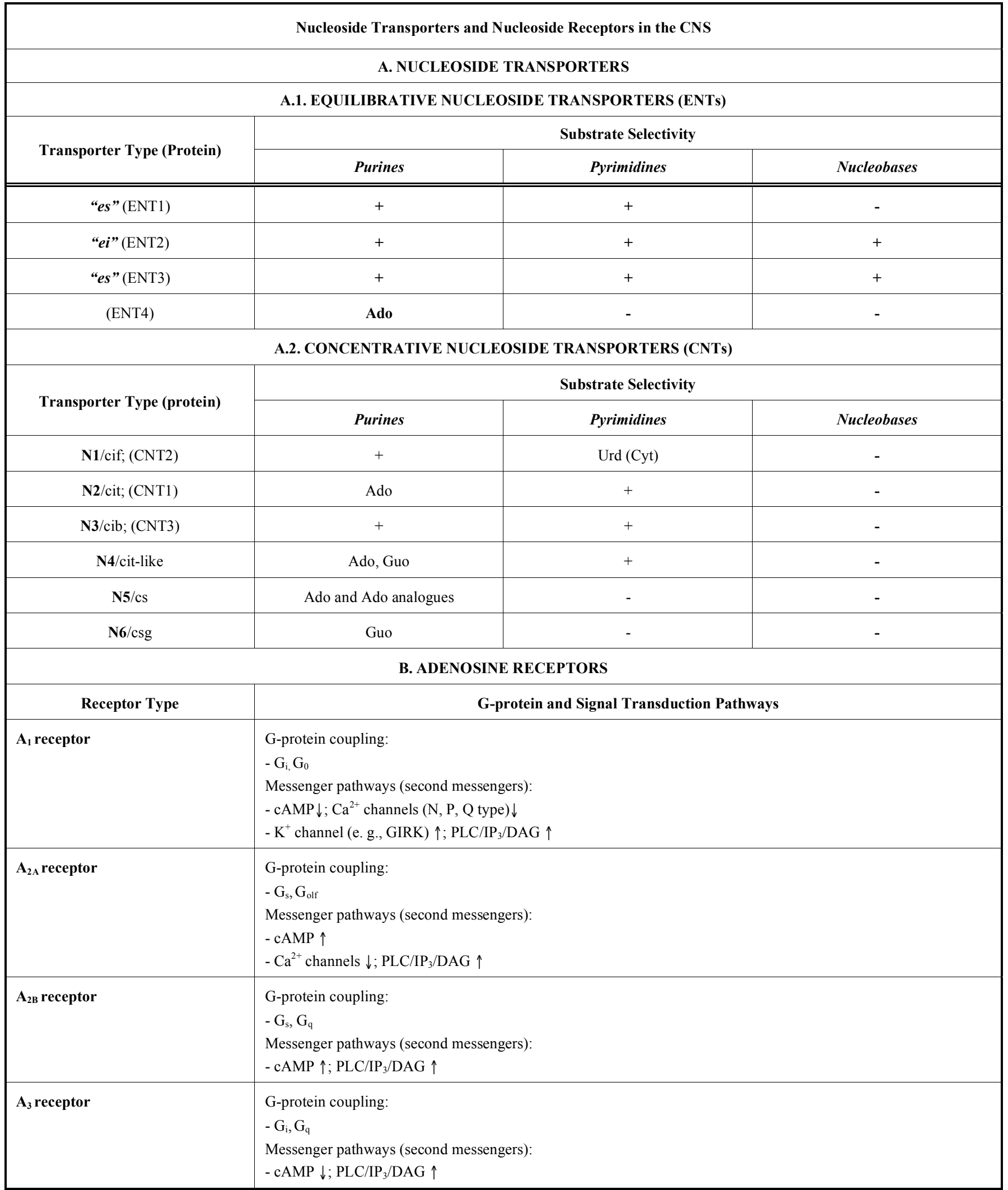

Abbreviations: Ado: adenosine; cAMP: cyclic adenosine monophosphate; CNT1/CNT2/CNT3 transporters: CNT1/CNT2/CNT3 subtype of concentrative nucleoside transporters; Cyt: cytosine; DAG: diacylglycerol; ENT1/ENT2/ENT3/ENT4 transporters: ENT1/ENT2/ENT3/ENT4 subtype of equilibrative nucleoside transporters; "ei": equilibrative, NBTI (S(4-nitrobenzyl)-6-thioinosine) insensitive type of ENTs; "es": equilibrative, NBTI sensitive type of ENTs; $\mathrm{G}_{\mathrm{i}, \mathrm{G}} \mathrm{G}_{0}, \mathrm{G}_{\mathrm{s}}, \mathrm{G}_{\mathrm{q}}, \mathrm{G}_{\mathrm{olf}}$ : G-proteins; GIRK: G-protein-dependent inwardly rectifying $\mathrm{K}^{+}$channels; Guo: guanosine; IP 3 : inositol 1,4,5-triphosphate; PLC: phospholipase C; Urd: uridine 
epilepsy $[58,60-64,70]$. In this review, we summarize what is known about the nucleoside system in the brain in relation to its potential application against epileptic seizures.

\section{THE NUCLEOSIDE SYSTEM IN THE BRAIN}

The metabolism of nucleosides is well understood in the brain [30, 41, 71-77]. Purines and pyrimidines are synthesized (de novo) from precursor molecules such as carbon dioxide, aspartate, 5-phosphoribosyl-1-pyrophosphate (PRPP), glutamine, glycine and formyl groups, as well as from aspartate and carbamyl-phosphate. Purine and pyrimidine bases connect to a D-ribose in ribonucleosides or to a 2-deoxy-D-ribose in deoxyribonucleosides [78-80].

The catabolism of nucleotides may occur through several different routes in the brain [30, 40, 41, 72]. Adenosine triphosphate (ATP), Urd triphosphate (UTP) and Guo triphosphate (GTP) are degraded to their corresponding monophosphates, namely, Ado monophosphate (AMP), Urd monophosphate (UMP) and Guo monophosphate (GMP), respectively, by nucleoside di- and triphosphate phosphatases (Fig. 1). Metabolism of AMP can lead to the production of Ado or Ino monophosphate (IMP), whereas GMP may degrade to Guo and IMP. The synthesis of Ado from Sadenosylhomocysteine (SAH) by adenosylhomocysteinase (SAHH, S-adenosylhomocysteine hydrolase) has also been demonstrated [81]. Additionally, GMP $\rightarrow$ IMP, IMP $\rightarrow$ GMP, $\mathrm{AMP} \rightarrow \mathrm{IMP}$ and $\mathrm{IMP} \rightarrow \mathrm{AMP}$ conversions have been demonstrated in the CNS. The converting enzymes are as follows: cytoplasmic 5'-nucleotidase (5'NT, cN), GMP reductase (GMPR), GMP synthetase (GMPS), IMP dehydrogenase (IMPDH), AMP deaminase (AMPDA), adenylosuccinate lyase (ASL) and adenylosuccinate synthetase (ASS) (Fig. 1). 5'-Nucleotidase also metabolizes UMP to Urd. The degradation pathway of Ado and Guo can lead to uric acid (UA) via Ino, hypoxanthine (Hyp), xanthine (Xn) (Fig. 1) and via guanine (Gn) and Xn (Fig. 1) by purine nucleoside phosphorylase (PNP), Gn deaminase (GDA), Xn oxidase (XO) and Ado deaminase (ADA) [41, 71, 73, 74].

Urd may be metabolized to dihydrouracil (DHU) via uracil (Ura) by dihydropyrimidine dehydrogenase (DPD) and Urd phosphorylase (UP). The extracellular (EC) level of Ado is maintained and regulated by ecto-5'-nucleotidase (ecto5'NT, eN, e5'NT), ecto-Ado kinase (ecto-ADK) and ectoAdo deaminase (ecto-ADA) [72, 75, 76] (Fig. 1). The intracellular (IC) salvage mechanism maintains the synthesis of ribo- and deoxyribonucleotides by preserving the purine and pyrimidine nucleosides and their bases. For instance, Нyp and Gn may be converted to IMP and GMP by Hyp phosphoribosyltransferase (HGPRT; hypoxanthine-guanine phosphoribosyltransferase) (Fig. 1), whereas Ado, adenine (Ade) and Urd are converted to AMP and UMP by ADK, Ade phosphoribosyltransferase (APRT) and Urd-cytidine (Cyd) kinase (UCK), respectively [30, 77].

Nucleosides are released from brain cells by reverse transport through specific transporters at the cell membrane [43] (Table 1). All six (N1-N6) concentrative nucleoside transporters (CNT transporters), which are sodiumdependent and unidirectional, are present in the CNS. Expression of equilibrative nucleoside transporters (ENT1ENT4; bidirectional by facilitated diffusion) (Table 1) has also been demonstrated in the brain $[30,43,82]$. The S-(4nitrobenzyl)-6-thioinosine (NBTI) sensitive ENTs ("es") are inhibited by low levels of NBTI (on the order of nM concentrations), whereas NBTI insensitive ENTs ("ei") are inhibited by higher concentrations of NBTI (on the order of $\mu \mathrm{M}$ ). Nucleoside base transporters are also detected in the brain $[30,43,82]$.

Expression of G-protein-coupled Ado receptor subtypes $\left(G_{i}\right.$ and $G_{0}$ or $G q$ : $A_{1}$ and $A_{3}$ receptor; $G_{s}$ and $G_{\text {olf }}$ or $G_{q}: A_{2 A}$, $A_{2 B}$ receptor) has been detected in the CNS [30, 32]. Signaling mechanisms activated by Ado receptors [32] are summarized in (Fig. 1 and Table 1). In addition, a great deal of evidence suggests that both Urd [83, 84] and Guo [50, 51] may bind to their selective receptors, most likely the G-proteincoupled receptors UrdR and GuoR, in the CNS (Fig. 1).

\section{MODULATORY ROLE OF NUCLEOSIDES ON EPILEPTIC ACTIVITY}

The modulatory role of Ado in different brain diseases involving epilepsy has been investigated extensively [31, 32, 85-87], and some of the drugs that have effects on the adenosinergic system (e.g., ADK inhibitors) may also be used in the treatment of epileptic seizures $[32,86]$. However, nonAdo nucleosides, such as Guo, Ino and Urd, may also decrease the EC level of the excitatory neurotransmitter glutamate and/or increase GABAergic inhibition [88-90] and participate in pathophysiological processes of epilepsy [58-64]. Consequently, not only Ado [27, 33, 65-67] but also nonAdo nucleosides (e.g., Ino, Guo and Urd) and their derivatives may be potential drugs in the treatment of different types of epilepsies. Therefore, in this review, we focused on the effects of Ado, Ino, Guo and Urd on epileptic activity.

\subsection{Adenosine}

Adenosine, a neuromodulator agent, is the primary inhibitor of neuronal activity. Consequently, it may serve as an endogenous anticonvulsant molecule. Its inhibitory action is mainly exerted by $A_{1}$ receptors, although $A_{2 A}$ receptors may also be involved in different epilepsy models [91-96] (Table 3). $A_{1}$ receptor expression has been observed both presynaptically and postsynaptically. Presynaptic receptors decrease the release of neurotransmitters, whereas they stabilize the membrane potential postsynaptically [97-100]. It is likely that $\mathrm{G}_{\mathrm{i} / 0}$ proteins are involved in these actions [99, 101]. It has also been demonstrated in the hippocampus that glutamate increases the Ado level via NMDA receptor activation, which may inhibit glutamate release presynaptically via $A_{1}$ receptors [102]. The inhibition by Ado may be sufficient (i) to regulate the spreading of seizures, (ii) to decrease epileptic activity (Table 3 ) and (iii) for seizure termination [96, 101, 103-108]. An increase in the Ado level in epileptic brain tissue has been demonstrated [109-112]. Consequently, increasing the Ado level in the brain by specific inhibitors of nucleoside metabolic enzymes (e.g., ADA and ADK inhibitors) and nucleoside transporters (Table 2; Fig. 2A and 2B), or by Ado-releasing grafts (in which Ado metabolizing enzymes are inactivated) (Table 4), ketogenic diets or direct (focal) infusion of Ado (Table 4) may have seizurepreventing/decreasing effects [110, 113-121]. 
Table 2. Effects of Nucleoside Metabolic Enzyme Inhibitors and Nucleoside Transporter Inhibitors on Seizures in Different Type of Epilepsy Models

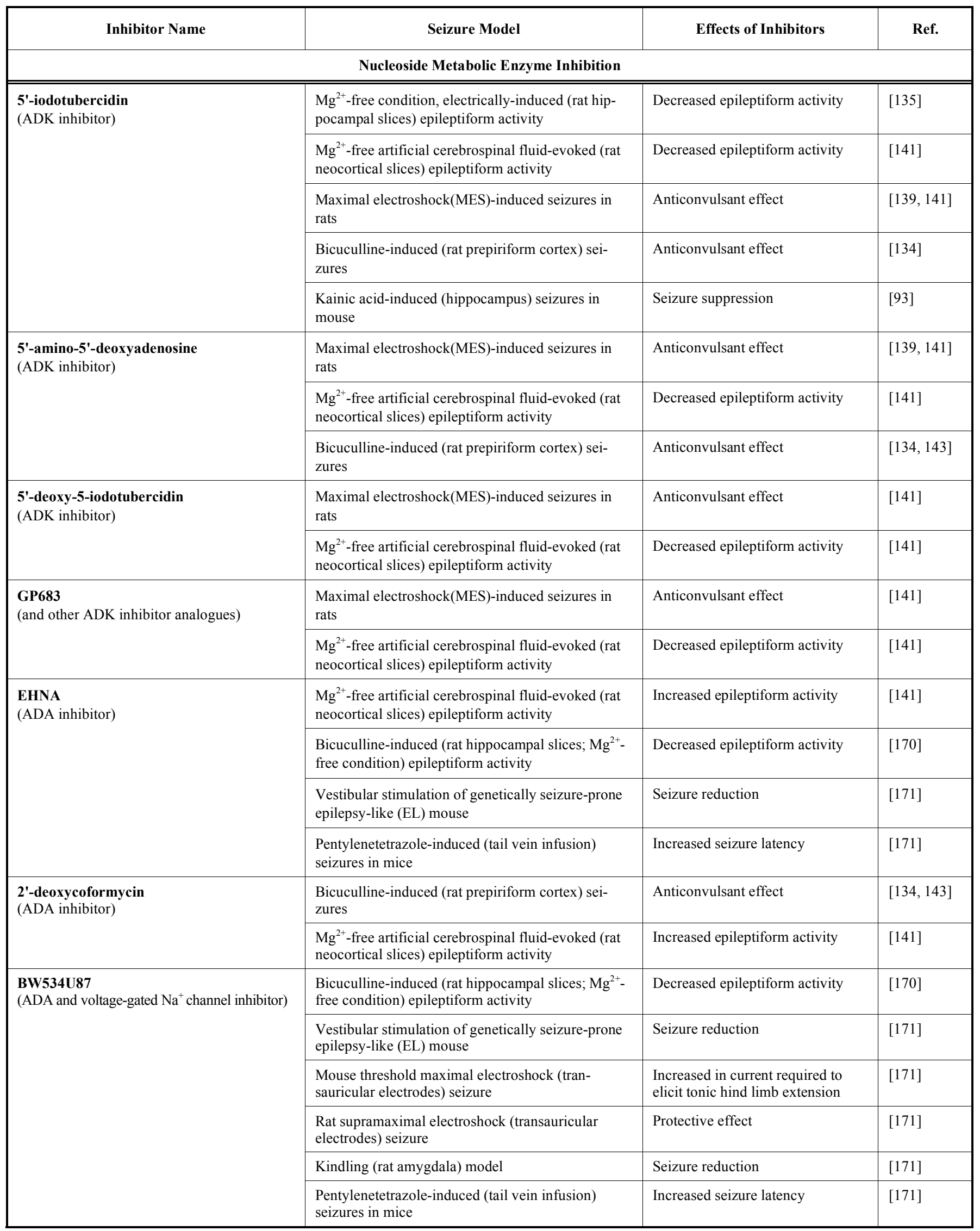


(Table 2) contd....

\begin{tabular}{|c|c|c|c|}
\hline Inhibitor Name & Seizure Model & Effects of Inhibitors & Ref. \\
\hline \multicolumn{4}{|c|}{ Nucleoside Metabolic Enzyme Inhibition } \\
\hline $\begin{array}{l}\text { Allopurinol } \\
\text { (XO inhibitor) }\end{array}$ & $\begin{array}{l}\text { Epileptic patients with tonic clonic generalized } \\
\text { seizure, generalized tonic, generalized atonic, or } \\
\text { complex partial seizure, etc. }\end{array}$ & Seizure reduction & {$[172-176]$} \\
\hline \multicolumn{4}{|c|}{ Nucleoside Transporter Inhibition } \\
\hline \multirow[t]{4}{*}{ Dipyridamole } & $\begin{array}{l}\text { Pentylenetetrazole-induced (intravenous applica- } \\
\text { tion) seizures in mice }\end{array}$ & Increased seizure threshold & {$[215]$} \\
\hline & $\begin{array}{l}\mathrm{Mg}^{2+} \text {-free artificial cerebrospinal fluid-evoked (rat } \\
\text { neocortical slices) epileptiform activity }\end{array}$ & Decreased epileptiform activity & [141] \\
\hline & $\begin{array}{l}\text { Bicuculline-induced (rat hippocampal slices) } \\
\text { epileptiform activity }\end{array}$ & Decreased epileptiform activity & [168] \\
\hline & $\begin{array}{l}\text { Lithium-pilocarpine-induced status epilepticus in } \\
\text { rats }\end{array}$ & Protective effect & [216] \\
\hline \multirow[t]{2}{*}{ NBTI } & $\begin{array}{l}\mathrm{Mg}^{2+} \text {-free artificial cerebrospinal fluid-evoked (rat } \\
\text { neocortical slices and human neocortical slices) } \\
\text { epileptiform activity }\end{array}$ & Decreased epileptiform activity & {$[141,219]$} \\
\hline & $\begin{array}{l}\text { Bicuculline-induced (rat prepiriform cortex) sei- } \\
\text { zures }\end{array}$ & Anticonvulsant effect & [134] \\
\hline \multirow[t]{2}{*}{ Dilazep } & $\begin{array}{l}\text { Bicuculline-induced (rat prepiriform cortex) sei- } \\
\text { zures }\end{array}$ & Anticonvulsant effect & {$[134,143]$} \\
\hline & $\begin{array}{l}\text { Kainic acid-induced (rat prepiriform cortex) sei- } \\
\text { zures }\end{array}$ & Seizure protection & {$[214]$} \\
\hline \multirow[t]{4}{*}{ Papaverine } & $\begin{array}{l}\text { Ketamine-induced (intraperitoneal injection) } \\
\text { epileptiform activity }\end{array}$ & Decreased epileptiform activity & [217] \\
\hline & Kindling (rat amygdala) model & Seizure suppression & {$[213]$} \\
\hline & $\begin{array}{l}\text { Theophylline-induced (intravenous application) } \\
\text { seizures }\end{array}$ & Proconvulsant effect & {$[224]$} \\
\hline & $\begin{array}{l}\text { Bicuculline-induced (rat prepiriform cortex) sei- } \\
\text { zures }\end{array}$ & Anticonvulsant effect & {$[134]$} \\
\hline Soluflazine & $\begin{array}{l}\mathrm{Mg}^{2+} \text {-free condition, electrically-induced (guinea- } \\
\text { pig hippocampal slices) epileptiform activity }\end{array}$ & Decreased epileptiform activity & [218] \\
\hline
\end{tabular}

Abbreviations: ADA: adenosine deaminase; ADK: adenosine kinase; BW534U87: (1-[(2,6-difluorophenyl)-methyl]-1H-1,2,3-triazolo[4,5-c]) pyridine-4-amine mono hydrochloride); GP683: 4-(N-phenylamino)-5-phenyl-7-(5'-deoxyribofuranosyl)pyrrolo[2, 3-d]pyrimidine; EHNA: erythro-9-(2-hydroxy-3-nonyl)adenine; NBTI: S-(4-nitrobenzyl)-6-thioinosine; Ref.: references; XO: xanthine oxidase

Table 3. Effects of Adenosine Receptor Agonists and Antagonists on Seizures in Different Type of Epilepsy Models

\begin{tabular}{|c|c|c|c|}
\hline Drug Name & Seizure Model & Effects of Drugs & Ref. \\
\hline \multicolumn{4}{|c|}{ Ado Receptor Agonists } \\
\hline \multirow{5}{*}{$\begin{array}{l}\text { NECA } \\
\text { (non-selective } \\
\text { adenosine receptor } \\
\text { agonist) }\end{array}$} & Kindling (rat amygdala, caudate nucleus) model & Seizure reduction & {$[119,272]$} \\
\hline & Pentylenetetrazole-induced (intraperitoneal injection) seizures in rats & Seizure reduction & {$[256]$} \\
\hline & Bicuculline-induced (rat hippocampal slices) epileptiform activity & Decreased epileptiform activity & {$[168]$} \\
\hline & Bicuculline-induced (tail vein infusion) seizures in rats & Increased seizure threshold & [143] \\
\hline & Audiogenic seizures (audiogenic-seizure-sensitive DBA/2 mice) & Seizure prevention & {$[95]$} \\
\hline
\end{tabular}


(Table 3) contd....

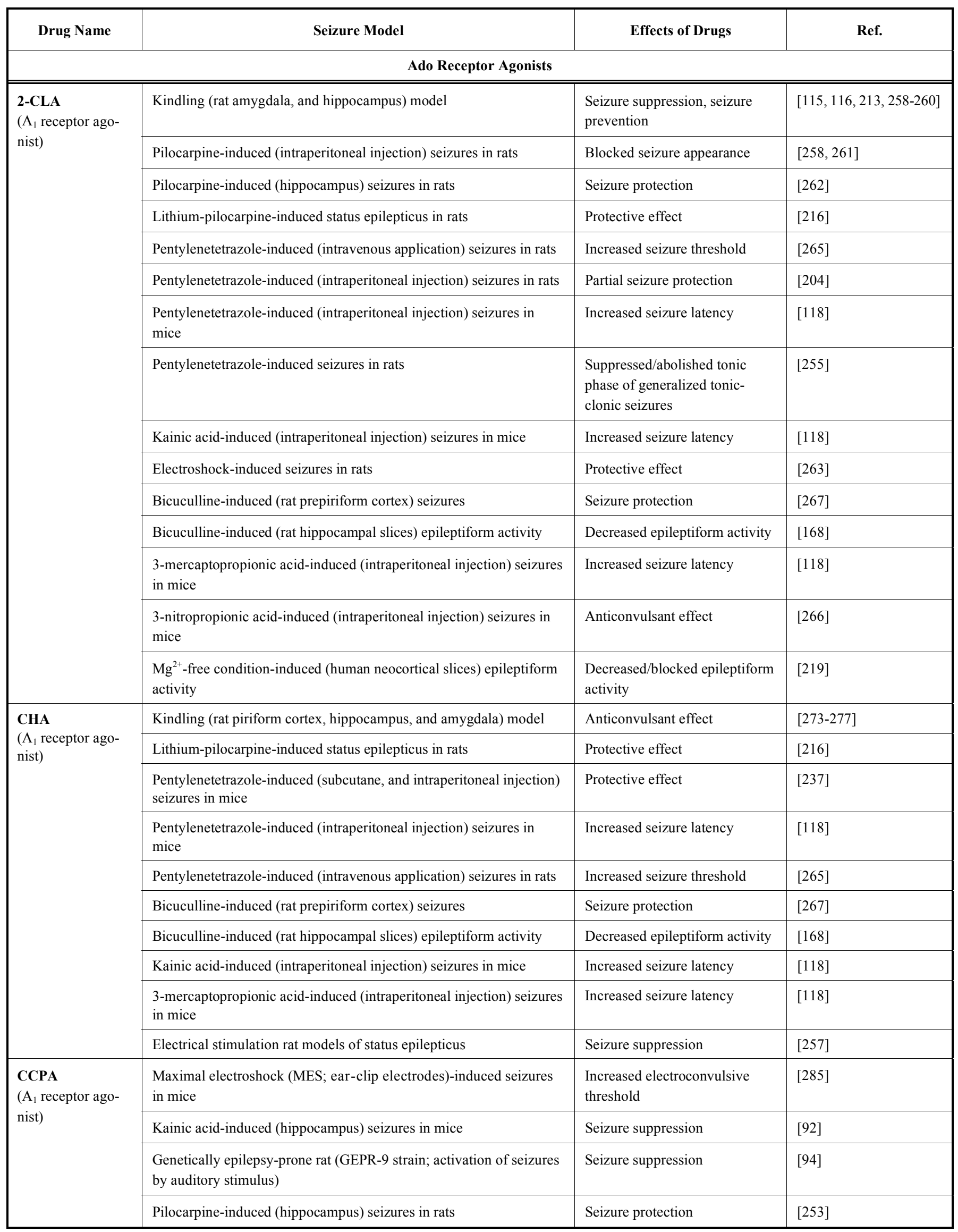


(Table 3) contd....

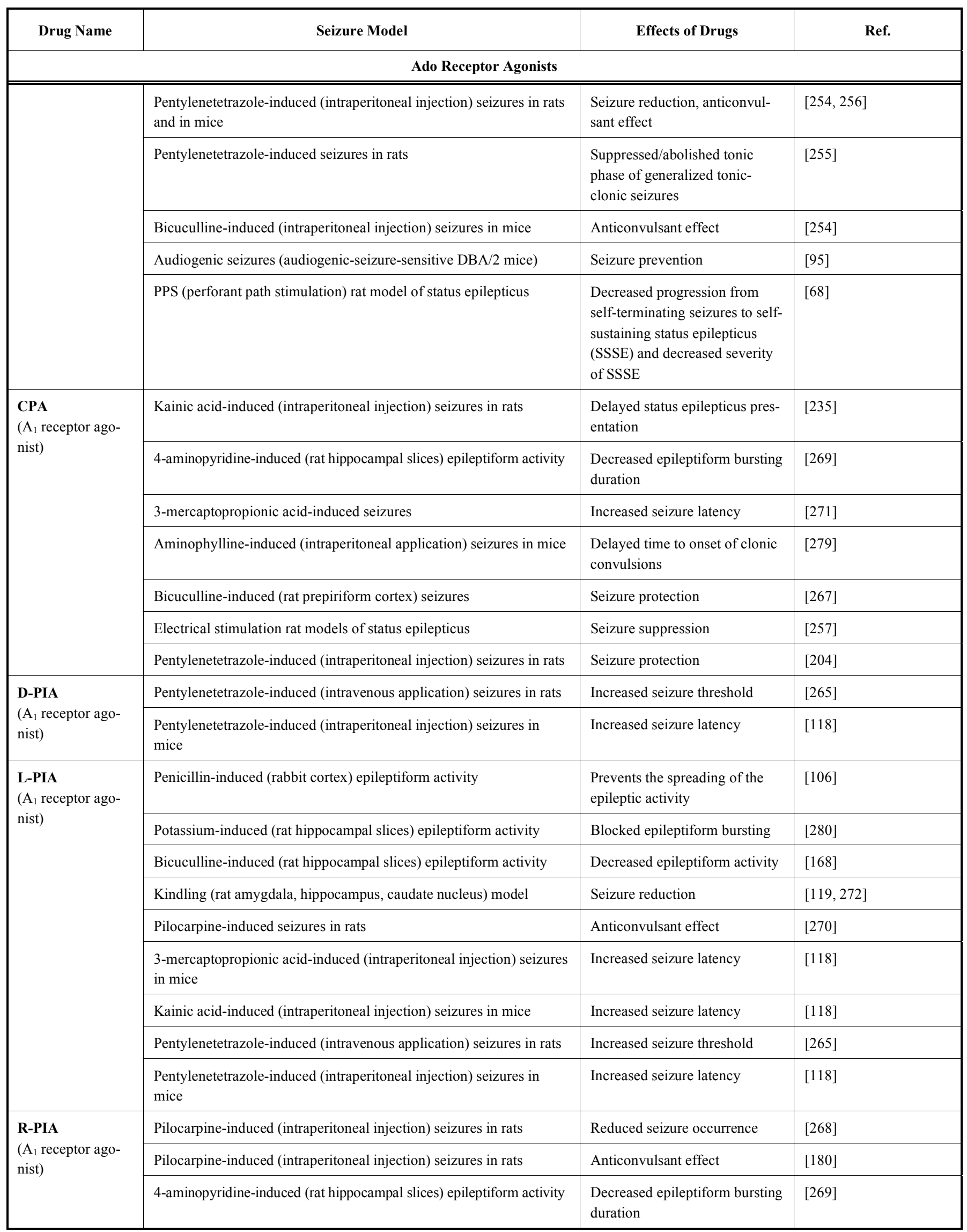


(Table 3) contd....

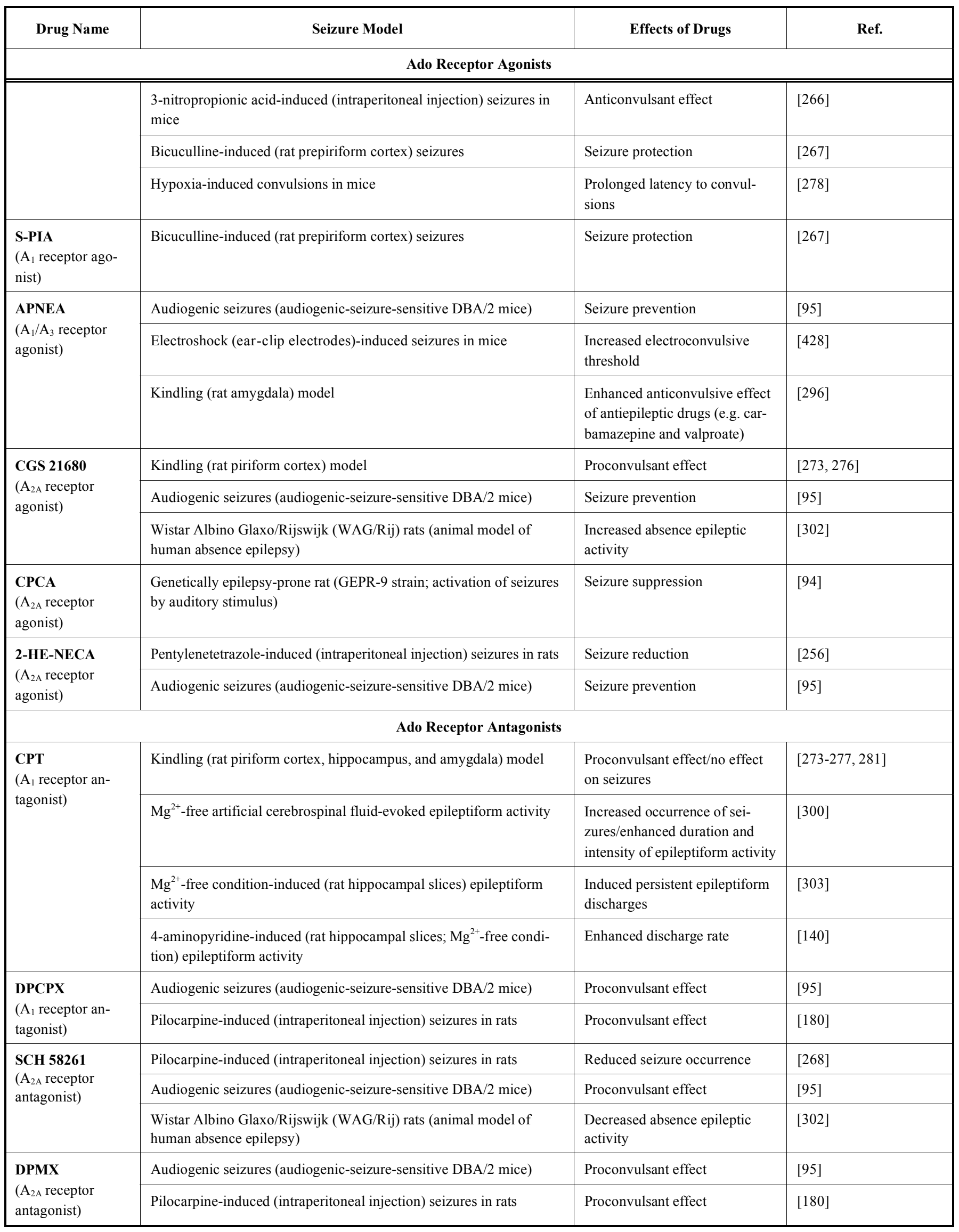


(Table 3) contd....

\begin{tabular}{|c|c|c|c|}
\hline \multicolumn{4}{|c|}{ Ado Receptor Antagonists } \\
\hline \multirow{2}{*}{$\begin{array}{l}\text { ZM } 241385 \\
\text { (A } A_{2 A} \text { receptor } \\
\text { antagonist) }\end{array}$} & Kindling (rat amygdala) model & Anticonvulsant effect & {$[301]$} \\
\hline & Pentylenetetrazole-induced seizures in rats & $\begin{array}{l}\text { Moderately suppressed tonic } \\
\text { phase of generalized tonic- } \\
\text { clonic seizures }\end{array}$ & {$[255]$} \\
\hline $\begin{array}{l}\text { MRS } 1191 \\
\text { ( } \mathrm{A}_{3} \text { receptor } \\
\text { antagonist) }\end{array}$ & $\mathrm{Mg}^{2+}$-free artificial cerebrospinal fluid-evoked epileptiform activity & Decreased epileptiform activity & {$[300]$} \\
\hline
\end{tabular}

Abbreviations: 2-CLA: 2-chloroadenosine; 2-HE-NECA: 2-hexynyl-5'-N-ethyl-carboxamidoadenosine; Ado: adenosine; APNEA: ${ }^{6}$-2-(4-aminophenyl)ethyladenosine; CCPA: 2chloro- $\mathrm{N}^{6}$-cyclopentyladenosine; CGS 21680: (2-(4-(2-carboxyethyl)-phenylamino)-5'-N-ethylcarboxamidoadenosine; CHA: $\mathrm{N}^{6}$-cyclohexyladenosine; CPA: $\mathrm{N}^{6}$-cyclopentyladenosine; CPCA: 5'-(N-cyclopropyl)-carboxamido-adenosine; CPT: 8-cyclopentyl-1,3-dimethylxanthine; DPCPX: 8-cyclopentyl-1,3-dipropylxanthine; D-PIA: D-N ${ }^{6}$-(2phenylisopropyl) adenosine; DPMX: 3,7-dimethyl-1-propylxanthine; KF 17837: (E,18\%-Z,82\%)7-methyl-8-(3,4-dimethoxystyryl)-1,3-dipropylxanthine; L-PIA: L-N-(2phenylisopropyl) adenosine; MRS 1191: 3-ethyl-5-benzyl-2-methyl-4-phenylethynyl-6-phenyl-1,4-( \pm )-dihydropyridine-3,5-dicarboxylate; NECA: 5'-(N-ethyl)carboxamidoadenosine; Ref.: references; R-PIA: R-N ${ }^{6}$-(2-phenylisopropyl) adenosine; SCH 58261: 5-amino-7-(2-phenylethyl)-2-(2-furyl)-pyrazolo-(4,3-c)1,2,4-triazolo(1,5 -c)-pyrimidine; SPIA: S-N ${ }^{6}$-(2-phenylisopropyl) adenosine; ZM 241385: 4-(2-[7-amino-2-[2-furyl]-[1,2,4] triazolo [2,3-a] \{1,3,5\}triazin-5-yl-amino] ethyl)phenol

\section{A, ADK inhibitors}

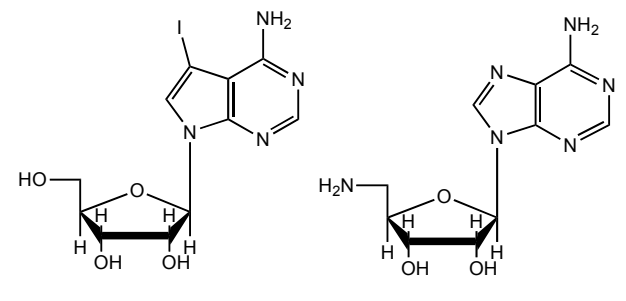

5-iodotubercidin

5'-amino-5'-deoxyadenosine

B, ADA inhibitors<smiles>CCCCCCC(C)(C)C(C)(C)O</smiles>

EHNA

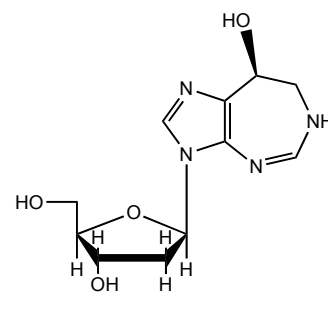

2'-deoxycoformycin<smiles>C[C@H](O)[C@H](O)[C@H](O)n1cc(I)c2c(N)ncnc21</smiles>

5'-deoxy-5-iodotubercidin

C, XO inhibitor

D, Nucleoside transporter inhibitors<smiles>OCCN(CCO)c1nc(N2CCCCC2)c2nc(N(CCO)CCO)nc(N3CCCCC3)c2n1</smiles>

Dipyridamole

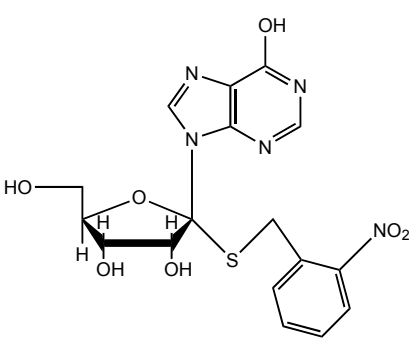

NBTI

Fig. (2). The chemical structure of some ADK, ADA and XO inhibitors and nucleoside transporter blockers previously used in epilepsy research. Abbreviations: EHNA: erythro-9(2-hydroxy-3-nonyl)adenine; NBTI: S-(4-nitrobenzyl)-6-thioinosine. 
Table 4. Effects of Nucleosides on Seizures in Different Type of Epilepsy Models

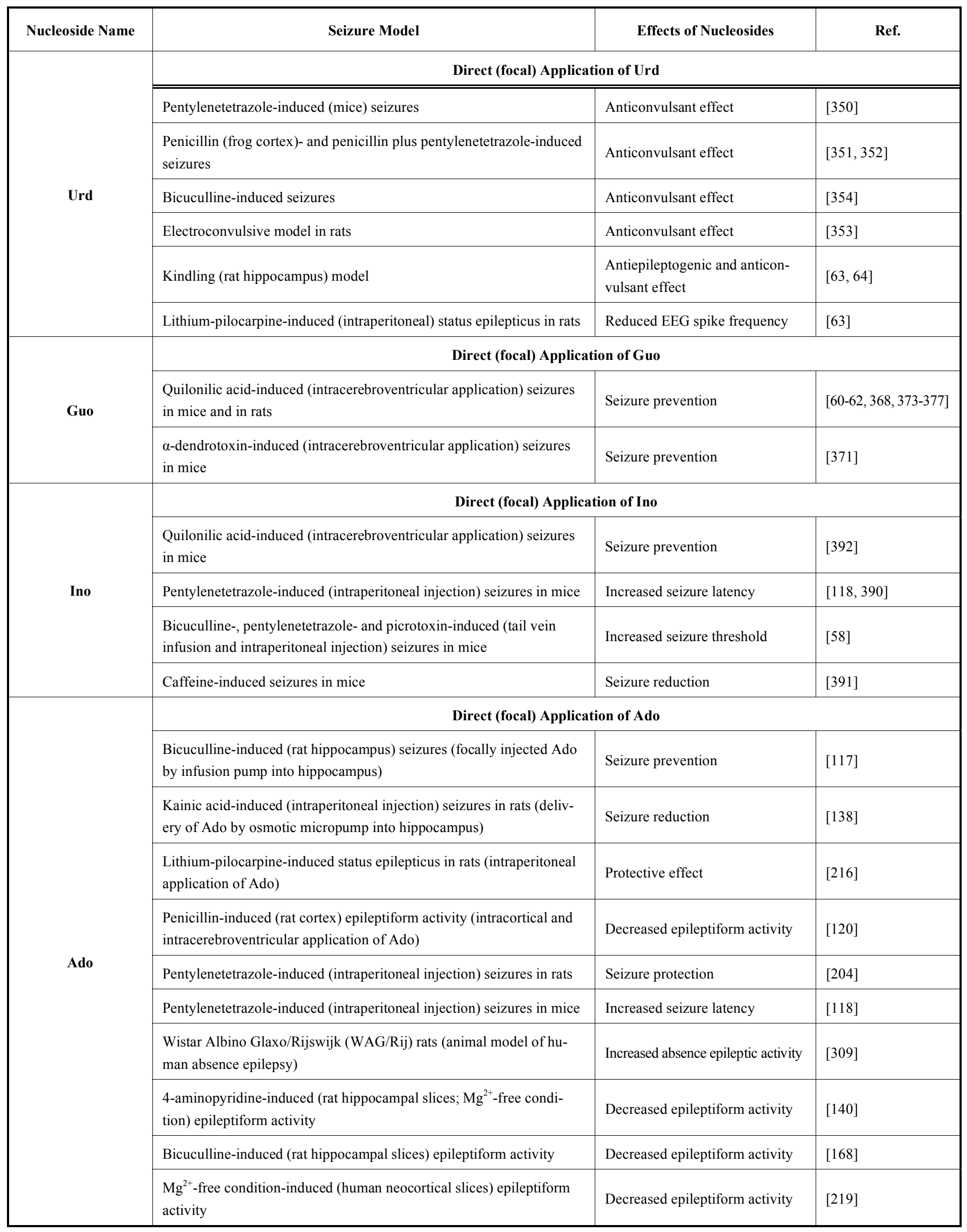


(Table 4) contd....

\begin{tabular}{|c|c|c|c|}
\hline & \multicolumn{3}{|c|}{ Adenosine-releasing Polymers (Brain Implants) } \\
\hline & $\begin{array}{l}\text { Kindling (rat hippocampus) model (Ado releasing silk-based polymer } \\
\text { implanted into rat infrahippocampal fissure) }\end{array}$ & $\begin{array}{l}\text { Seizure suppression and retarda- } \\
\text { tion of kindling acquisition }\end{array}$ & {$[407,408]$} \\
\hline & $\begin{array}{l}\text { Downregulation of ADK by adenoassociated virus 8(AAV8)-mediated } \\
\text { RNA interference in the hippocampus of spontaneously epileptic Adk- } \\
\text { tg/ADK overexpressing transgenic mouse }\end{array}$ & Seizure reduction & [414] \\
\hline & $\begin{array}{l}\text { Mouse model of focal epileptogenesis, kainic acid-induced (mouse } \\
\text { amygdala) seizures (human mesenchymal stem cells with a knock- } \\
\text { down of ADK by lentiviral RNAi transplanted into mouse infrahippo- } \\
\text { campal fissure) }\end{array}$ & Seizure reduction & [410-412] \\
\hline & $\begin{array}{l}\text { Kindling (rat hippocampus) model (encapsulated Ado releasing cells, } \\
\text { fibroblasts, myoblasts, glial precursor cells and baby hamster kidney } \\
\text { cells implanted into the rat lateral ventricle) }\end{array}$ & Seizure suppression & {$[113,417,419,420]$} \\
\hline & $\begin{array}{l}\text { Kindling (rat hippocampus) model (Ado releasing mouse embryonic } \\
\text { stem cell-derived neural progenitor cells implanted into rat infrahippo- } \\
\text { campal fissure) }\end{array}$ & $\begin{array}{l}\text { Suppressed kindling epilepto- } \\
\text { genesis }\end{array}$ & {$[422]$} \\
\hline & $\begin{array}{l}\text { Mouse model of focal epileptogenesis, kainic acid-induced (mouse } \\
\text { amygdala) seizures (Ado releasing mouse embryonic stem cell-derived } \\
\text { neural progenitor cells implanted into mouse infrahippocampal fissure) }\end{array}$ & Lack of spontaneous seizures & {$[165]$} \\
\hline
\end{tabular}

Abbreviations: ADK: adenosine kinase; Ado: adenosine; Guo: guanosine; Ino: inosine; Ref.: references; Urd: uridine

\subsubsection{Modulation of Adenosine Levels and Epileptic Activ- ity by Metabolic Enzymes}

Regionally different Ado levels have been demonstrated in the human brain tissue [56]. The highest Ado concentrations $(17.2-23.9 \mathrm{pmol} / \mathrm{mg})$ were measured in the vestibular nuclei, cochlear nuclei and cerebellar cortex, while the lowest levels (1.4-2.4 pmol $/ \mathrm{mg})$ were demonstrated in the entorhinal cortex, locus coeruleus, habenula and zona incerta. Different cortical areas and limbic areas may be involved in epileptogenesis; the entorhinal cortex and hippocampus contained low to medium levels of Ado [56]. In addition, the highest Ado immunoreactivity was determined in the pyramidal cells of the hippocampus and granule cells of the dentate gyrus [122]. Approximately two-fold higher EC Ado levels were measured in the rat striatum $(1.92 \mu \mathrm{M})$ than in the hippocampus $(0.93-0.95 \mu \mathrm{M})$ and thalamus $(0.95 \mu \mathrm{M})$ [112, 123-126]. In addition, uneven distributions of ADA activity and ADK activity, which may regulate Ado levels in the brain tissue, were revealed in the different brain areas. For example, the activity of ADA was intermediate to low in the hippocampus and intermediate to high in the cortical areas [31, 127-129], and intermediate/low and very low levels of ADK activity were demonstrated in the cortex and hippocampus, respectively $[31,93,130]$. ADA activity decreased with age in the cortex and hippocampus [131], which may induce an increase in Ado levels in elderly people. Indeed, concentrations of Ado exhibit age-dependent alterations in the human cerebral cortex (Ado concentration was higher in the elderly compared with middle-aged subjects) [57] and in all areas of the rat brain [132]. The highest level of SAH in the rat striatum and its modification by age has also been demonstrated [132, 133], suggesting that SAHH activity is also unevenly distributed and may change with age in the brain.

Because of its lower $K_{\mathrm{m}}$ value (ADK: $2.0 \mu \mathrm{M}$; ADA: $17.0 \mu \mathrm{M})[130]$, ADK may be the key enzyme in Ado-level modulation $[66,134]$; thus, inhibition of ADK by ADK inhibitors (e.g., 5'-iodotubercidin, 5'-amino-5'-deoxyadenosine, 5'-deoxy-5-iodotubercidin (Fig. 2A) and 4-(N-phenylamino)5-phenyl-7-(5'-deoxyribofuranosyl)pyrrolo[2,3-d]pyrimidine /GP683) (Table 2), which disrupts the metabolic clearance of Ado, induces an increase in the release of neuroprotective endogenous Ado [135-137]. An increased concentration of Ado enhances $\mathrm{A}_{1}$-mediated presynaptic inhibition in the hippocampus [136] and decreases the seizure activity in different models of epilepsy, such as the maximal electroshock (MES) seizure model, the kainic acid mouse and rat models, the $\mathrm{Mg}^{2+}$-free condition-induced epilepsy model and the bicuculline-induced seizure model [93, 134, 135, 138-143]. The role of ADK in the modulation of epileptic activity was strengthened by Gouder et al. [93] in the epileptic hippocampus in which overexpressed ADK decreased the level of Ado $[27,144]$ and increased epileptic activity, whereas reduced ADK activity by the ADK inhibitor 5'-iodotubercidine decreased epileptic activity. Astrocytes play crucial role in ADK-dependent modulation of Ado levels [27, 135, 144, 
145] because ADK expression was greatest in the astrocytes in the adult brain [146], and the largest Ado release was measured from astrocytes (derived indirectly from degradation of astrocyte-released ATP and directly via nucleoside transporters) [29, 147-150]. It has also been demonstrated that an increase of ADK expression under pathological conditions may cause an Ado deficiency, which may be considered a pathological hallmark of epilepsy [151].

Epilepsy-precipitating effects, such as hypoxia, brain injury and inflammation, may induce $A_{2 \mathrm{~A}}$ receptor upregulation and an increase in Ado levels [152]. Rapid, acute downregulation of ADK expression has also been demonstrated after status epilepticus [93], which may increase Ado levels transiently and decrease epileptic activity (initial seizure suppression) by an endogenous astrocyte-based antiseizure mechanism in the brain [27, 65]. However, a subsequent high, acute Ado concentration promotes glial activation and astrogliosis, one of the relevant features of the epileptic brain [153], via stimulation of $\mathrm{A}_{2 \mathrm{~A}}$ receptors [154, 155]. The expression of ADK by glial fibrillary acidic protein (GFAP)positive astrocytes and the overexpression of ADK in parallel with the formation of astrogliosis has been observed [27, $65,93,156]$. Additionally, although $\mathrm{A}_{1}$ receptors may reduce astrogliosis [157], expression of astrocytic $A_{1}$ receptors may be reduced by epileptogenesis [158-161]. $A_{2 A}$ receptors are upregulated by high Ado levels [27]; thus, the crucial role of Ado receptor expression in astrogliosis, the astrogliosisinduced increase in ADK activity and the disruption of Ado homeostasis have been suggested in epilepsy $[151,156,162$, 163]. It was concluded that (i) upregulation of ADK in chronic epilepsy mainly occurs in astrocytes via Adoreceptor-induced astrogliosis in the adult brain, (ii) high ADK activity in astrocytes results in a decrease of Ado concentration, which may induce chronic recurrent seizures, (iii) consequently, ADK may be the link between astrogliosis and neuronal dysfunction in epilepsy and (iv) astrogliosis and concomitant epileptic seizures may be prevented by Ado receptor modulation $[65,93,164,165]$. In addition, it has been demonstrated that not only neurons but also astrocytes may contribute to the initiation, maintenance and spread of seizures and the astrocytic basis of seizure activity [144, 153, 166]. Clinically used antiepileptics, such as carbamazepine and vigabatrin, modulate the physiological processes in the brain and induce undesirable side effects $[153,167]$, but astrocytes may be new therapeutic targets by which to reduce epileptic activity without suppressing the physiological neural activity.

Inhibition of both ADA and SAHH caused minimal effects on the Ado level under basal conditions and/or electrical stimulation $[136,137]$, whereas the effect of ADA in the modulation of Ado concentration was more significant when the Ado level was increased by energy depletion [137]. In addition, ADA may induce burst firing [168] and increase the amplitudes of extracellularly recorded field potentials [169] in the hippocampus. The results are controversial regarding the effect of ADA inhibition on epileptic activity (Table 2). While increased epileptiform activity induced by both the ADA inhibitor 2'-deoxycoformycin and erythro-9(2-hydroxy-3-nonyl)adenine (EHNA) (Fig. 2B) was observed in a $\mathrm{Mg}^{2+}$-free artificial cerebrospinal fluid (ACSF)induced model [141], it has also been demonstrated that the
ADA inhibitor BW534U87 decreased epileptic activity with minimal side effects in (i) a bicuculline-induced (rat hippocampal slices) epilepsy model, (ii) a seizure-prone epilepsylike (EL) mouse model, (iii) mouse threshold maximal electroshock seizures, (iv) rat supramaximal electroshock seizures, (v) a kindling rat model and (vi) a pentylenetetrazole (PTZ)-induced seizure model in mice $[170,171]$. In bicuculline- and PTZ-induced seizures and in the genetically seizure-prone epilepsy-like mice, EHNA and/or 2'deoxycoformycin were also effective against seizures [134, $143,170,171]$.

It was observed that the application of the XO inhibitor allopurinol (Table 2; Fig. 2C) as adjunctive therapy is effective in seizure reduction [172-176], in which allopurinol may act via a decrease of Ado and/or Guo degradation and an HGPRT-induced increase in Ado and Guo levels (Fig. 1) $[30,173]$. Because of its relatively mild and negligible side effects, it was concluded that allopurinol may be an effective and safe adjuvant against intractable epilepsy [173].

Increased e5'NT activity has been demonstrated in rat models of epilepsy induced by kainic acid, pentylenetetrazol and pilocarpine [177-181] and in patients with temporal lobe epilepsy [182]. In addition, the convulsant effect of e5'NT inhibition by $\alpha, \beta$-methyleneadenosine-5'-diphosphate (APCP) has been demonstrated in rats [134]. These results suggest that enhanced activity of e5'NT after epileptic seizures may be an adaptive response, which increases the concentration of EC Ado and, as a consequence, the anti-epileptic effects via $\mathrm{A}_{1}$ receptors; thus, modulation of e ${ }^{\text {' }} \mathrm{NT}$ activity may be a new promising therapeutic tool against epilepsy.

\subsubsection{The Specific Role of Adenosine in Inflammation- induced Epilepsy}

Inciting effects (e.g., status epilepticus and infection) may induce glial and neuronal activation in affected brain areas [183-185], which enhance the synthesis of proinflammatory cytokines (e.g., interleukin-1 $\beta$ (IL-1 $\beta$ ) and tumor necrosis factor $\alpha$ (TNF- $\alpha)$ ) [185-188]. Both IL-1 $\beta$ and TNF- $\alpha$ may increase EC glutamate levels, which may induce hyperexcitability and seizures [153, 189]. A lipopolysaccharide (LPS)-induced increase in IL- $1 \beta$ may also result in cortical epileptiform discharges [190], and the induction of IL-1 $\beta$ expression in astrocytes may have a role in the occurrence of absence seizures [191]. Because IL-1 $\beta$ and LPS increased ADK expression in astrocyte cultures [156], the link between the LPS-induced increase in IL-1 $\beta$ and absence epileptic activity $[192,193]$ may be the decreased level of endogenous anticonvulsant Ado by ADK. In addition, LPS and IL-1 $\beta$ induced the release of ATP from hippocampal slices [194], which may be metabolized extracellularly to Ado by ectonucleotidases $[72,75,76]$ resulting in stimulation of $\mathrm{A}_{2 \mathrm{~A}}$ receptors, which may downregulate the expression of $\mathrm{A}_{1}$ receptors [195] and enhance Ado uptake by ENT transporters [196]. All of these effects may increase epileptic activity by decreased Ado-induced inhibition via $\mathrm{A}_{1}$ receptors. An $\mathrm{A}_{2 \mathrm{~A}}$ receptor antagonist 5-amino-7-(2-phenylethyl)-2-(2-furyl)pyrazolo-(4,3-c)1,2,4-triazolo(1,5-c)-pyrimidine $\quad(\mathrm{SCH}$ 58261) prevented the LPS-induced increase in the IL-1 $\beta$ concentration in the hippocampus [152, 197], whereas the $\mathrm{A}_{2 \mathrm{~A}}$ receptor agonist (2-(4-(2-carboxyethyl)-phenylamino)- 
5'-N-ethylcarboxamido-adenosine (CGS 21680) decreased the release of TNF- $\alpha$ [198]. Because glial cells contain Ado receptors $[152,199-201]$ the adenosinergic system may decrease inflammation-induced epilepsy via $A_{1}$ receptors. Adenosine reduces astrocyte proliferation via $A_{1}$ receptors, whereas $\mathrm{A}_{2}$ receptors may induce it [201]; thus, high $\mathrm{A}_{1}$ receptor expression inhibits astrocyte proliferation, while $\mathrm{A}_{2 \mathrm{~A}}$ receptor upregulation increases it [201], which also suggests the link between the adenosinergic system and inflammationinduced epileptic activity. In addition, the anti-inflammatory action of ADK inhibitors has been demonstrated in different animal models [142, 202, 203]. Thus, ADK inhibitors may also have antiseizure activity. These results suggest that a therapeutic increase in Ado levels may decrease the risk of inflammation-induced epileptic seizures.

Fewer side effects were induced by ADK inhibitors than by intraperitoneally administered Ado-receptor-agonists, the effects of which included hypothermia, ataxia, cardiovascular side effects and sedation [118, 141, 204, 205]. Systemic application of ADK inhibitors as potential antiepileptic drugs is limited [86] by their cardiovascular and hypothermic side effects [141, 206], their sedative effect and their CNS hemorrhaging effect [93]. In addition, Boison et al. [207] demonstrated lethal hepatic steatosis in ADK knockout mice.

\subsubsection{Inhibition of Nucleoside Transporters}

Nucleoside transporters are also unevenly distributed in the brain. Medium to high ENT1 levels have been demonstrated in the human brain areas (e.g., cerebral cortex, basal ganglia and thalamus), whereas these brain areas contained intermediate to low levels of ENT2. The hippocampus showed low ENT1 and ENT2 levels, but intermediate and high ENT3 and ENT4 expression have been demonstrated in the human brain [208-210]. High CNT2 and CNT3 activity have been demonstrated in the human hippocampus, whereas intermediate to low expression was revealed in the cerebral cortex [211, 212].

Inhibitors of nucleoside transporters may increase the EC level of Ado, which may result in seizure suppression. Indeed, Ado uptake inhibitors, such as papaverine and/or dipyridamole, dilazep, hexobendine, soluflazine or NBTI (Fig. 2D), (i) attenuated the amygdale-triggered (kindling) seizure activity [213] and the burst-firing of neurons of hippocampal slices in the bicuculline-induced epilepsy model [168]; (ii) decreased PTZ-, pilocarpine-, bicuculline- and kainic-acid-induced seizures [134, 143, 214-216] and ketamine-induced epileptiform activity [217]; (iii) had depressant effects on synaptic responses [169]; (iv) inhibited epileptogenic population spikes (PS) [218] and (v) depressed epileptiform activity in a $\mathrm{Mg}^{2+}$-free medium [141, 219] (Table 2). The Ado uptake inhibitor, midazolam, depresses excitatory synaptic transmissions in the hippocampus [220]. In addition, Ado uptake inhibitors have less severe adverse effects compared to Ado receptor agonists [221, 222]. Some controversial results were described in relation to nucleoside transporter inhibition, e.g., papaverine may have pro- and anticonvulsant effects in different models [134, 213, 217, 223225]. These results suggested that although Ado transport inhibitors may be effective antiepileptic drugs in several types of epilepsies, one has to be cautious regarding their applicability.

\subsubsection{Adenosine Receptor Agonists and Antagonists}

It has been revealed that $A_{1}$ receptors are expressed at medium to high density in the cerebral cortex, hippocampus and in some thalamic nuclei. High $\mathrm{A}_{2 \mathrm{~A}}$ receptor density has been demonstrated in the basal ganglia, whereas medium to low levels were found in several brain areas, such as the cerebral cortex, thalamus and hippocampus [208, 226, 227]. In general, Ado levels in different brain areas show correlations with the distribution of Ado receptors. For example, low or moderate Ado concentrations in the human cerebral cortex and hippocampus correlate well with the medium to high $A_{1}$ receptor expression in these brain regions $[30,56]$ suggesting the involvement of Ado and its receptors in the modulation of hippocampal and cortical activity in pathological conditions such as epilepsy. It has also been supported by the demonstration of an epilepsy-induced decrease in $A_{1}$ receptor expression in chronic seizures [67, 158-160, 228] and adaptive changes in Ado receptors after seizures [111]. Activation of $\mathrm{A}_{2 \mathrm{~B}}$ receptors by elevated Ado levels may induce the release of proinflammatory interleukin-6 (IL6) from astrocytes leading to increased expression of $A_{1}$ receptors and their functions in the brain [229, 230], which may explain (i) the increase of $A_{1}$ receptor expression after seizures parallel with increasing Ado level and (ii) the higher level of IL-6 in the brain areas (e.g., in the hippocampus and cortex) of epileptic patients and rats [186, 231-233], which may have a protective effect against subsequent seizures [230]. In addition, an increase in $A_{1}$ receptor density has been demonstrated in the epileptic tissue, for example, in PTZ kindling mice and kainic-acid-treated rats, which may also be an adaptive/protective mechanism against hyperexcitability-induced seizures and convulsions [96, 230, 234239].

Age-related decrease in $\mathrm{A}_{1}$ receptor density was detected in both the cortex and hippocampus, whereas expression of $\mathrm{A}_{2 \mathrm{~A}}$ receptors was increased in these brain areas with age [240-245]. Changes in Ado receptor density may result in an imbalance between inhibitory ( $\mathrm{A}_{1}$ receptor) and excitatory $\left(\mathrm{A}_{2 \mathrm{~A}}\right.$ receptor) processes [242, 246-248], which could shift the excitatory/inhibitory balance toward excitation in elderly people. In addition, $\mathrm{A}_{2 \mathrm{~A}}$ receptor activation may inhibit $\mathrm{A}_{1}$ receptors [98, 249, 250]. As a consequence, the increased risk of excitation and the consequent excitation-induced pathological processes may increase the sensitivity to epileptic seizures in elderly people $[57,251,252]$.

Activation of $A_{1}$ receptors by acute administration of their selective agonists, such as 2-chloro- $\mathrm{N}^{6}$-cyclopentyladenosine (CCPA) (Table 3; Fig. 3A), decreased the progression from self-terminating seizures to self-sustaining status epilepticus (SSSE) and decreased the severity of SSSE in a rat model of status epilepticus [68]. In addition, CCPA decreased the seizure activity in kainic-acid-induced epilepsy [92], pilocarpine-induced seizures [253] and bicuculline- as well as PTZ-induced convulsions [254-256]. Both $\mathrm{A}_{1}$ receptor agonists $\mathrm{N}^{6}$-cyclohexyl-adenosine (CHA) and $\mathrm{N}^{6}$ cyclopentyl-adenosine (CPA) (Table 3) suppressed the development of status epilepticus in electrical stimulation mod- 
els in rats [257]. An Ado analogue $A_{1}$ receptor agonist 2chloroadenosine (2-CLA) (Table 3) showed antiseizure effects in amygdaloid and hippocampal kindled rats $[115,116$, 213, 258-260], pilocarpine-induced seizures [216, 258, 261, 262], electroshock-induced seizures [263], $\mathrm{Mg}^{2+}$-free conditions [219, 264], PTZ-induced seizures [118, 204, 255, 265], 3-nitropropionic-acid-induced seizures [266], kainic-acidand 3-mercaptopropionic-acid-induced seizures [118] and bicuculline-induced seizures [168, 267].

In addition, not only 2-CLA but also Ado receptor agonists 5'-(N-ethyl)carboxamidoadenosine (NECA; nonselective Ado receptor agonist) (Fig. 3B) [143, 168, 214, 256] and/or CPA [204, 235], CHA (Fig. 3A) [118, 168, 216, 237] and D-, L-, R- and S-N ${ }^{6}$-(2-phenylisopropyl) adenosine (D-, L-, R- and S-PIA; A 1 agonists) (Table 3; Fig. 3A) [118, $168,180]$ were effective against bicuculline- and/or kainicacid-, pilocarpin-, 3-nitropropionic-acid-, 3-mercaptopropionicacid- and PTZ-induced seizures/epileptiform activity as well as 4-aminopyridine-induced epileptiform bursting activity [235, 265-271] and in the rat kindling model [119, 272-277]. It has also been demonstrated that R-PIA prolonged the latency to convulsions in a hypoxia-induced model [278] and CPA delayed the time onset of clonic convulsions in aminophylline-induced seizures [279]. L-PIA blocked potassiuminduced epileptic activity [280] and prevented the spreading of penicillin-induced epileptic activity [106].

The proconvulsant effect of the selective $\mathrm{A}_{1}$ receptor antagonist, 8-cyclopentyl-1,3-dimethylxanthine (CPT) (Table 3), has also been demonstrated in kindled rats [273-277, 281]. The antiseizure role of $A_{1}$ receptors was recently strengthened because (i) $A_{1}$ receptor knockout mice showed spontaneous hippocampal seizures and high sensitivity to status epilepticus [282, 283] and (ii) seizure-activity-limiting effects of Ado ( $\mathrm{A}_{1}$ receptor)-induced attenuation of depolarizing $\mathrm{GABA}_{\mathrm{A}}$ receptor signaling has been demonstrated [284]. In addition, CCPA enhanced the antiseizure effect of carbamazepine in the mouse maximal electroshock seizure model [285]. It has also been demonstrated that a ketogenic (low-carbohydrate and high-fat) diet, which decreases the glucose level and increases the metabolism of ketones, may decrease seizure activity [286-288] by several hypothetic pathways, for example via enhanced levels of Ado and increased activation of $A_{1}$ receptors [121, 289-292]. A ketogenic-diet-induced low glucose level may induce ATP release from neurons, and ATP may be metabolized subsequently to Ado, which hyperpolarizes the membrane by opening $\mathrm{K}^{+}$-channels and decreases the release of excitatory neurotransmitters via $A_{1}$ receptors. In addition, Ado attenuated the amplitudes of extracellularly recorded field potentials in the CA1 region of the hippocampus [169], decreased the excitability of postsynaptic cells [293] and inhibited neurotransmitter release in the hippocampus [169, 293, 294] by increasing $\mathrm{K}^{+}$conductance [295]. The $\mathrm{A}_{1} / \mathrm{A}_{3}$ receptor agonist, $\mathrm{N}^{6}$-2-(4-aminophenyl)ethyladenosine (APNEA) (Table 3 ), increased the seizure threshold in electroshock-induced seizures in mice and enhanced the anticonvulsive effect of antiepileptic drugs [296]. All of these results suggest that Ado may have an endogenous anticonvulsant/antiepileptic effect $[70,143,168,297]$ via mainly its $A_{1}$ receptors, but the antiseizure effect of $\mathrm{A}_{2 \mathrm{~A}}$ receptors has also been suggested (Table 3) [94, 95, 256, 298].
In a genetic-epilepsy-prone rat (generalized brain stem epilepsy in GEPR-9 strain), both CCPA and the $\mathrm{A}_{2 \mathrm{~A}}$ receptor agonist, 5'-(N-cyclopropyl)-carboxamido-adenosine (CPCA) suppressed brainstem seizures [94]. CCPA, A $\mathrm{A}_{2 \mathrm{~A}}$ receptor agonists (CGS 21680 and 2-hexynyl-5'-N-ethylcarboxamidoadenosine (2-HE-NECA)), APNEA and NECA prevented the development of audiogenic seizures in audiogenicseizure-sensitive DBA/2 mice [95]. CCPA, 2HE-NECA and NECA decreased PTZ-induced seizures strengthening that both $A_{1}$ and $A_{2 A}$ receptor stimulation is involved in the suppression of seizures $[95,256]$. Thus, the activation of not only $A_{1}$ receptors but also $A_{2 A}$ receptors may have antiepileptic potential in certain types of epilepsies [299]. However, the $A_{2 A}$ receptor effect on epileptic seizures is controversial. Reduced seizure occurrence and seizure reduction have been demonstrated by the application of $\mathrm{A}_{2 \mathrm{~A}}$ receptor agonists (e.g., CPCA) $[94,95,256]$ and $\mathrm{A}_{2 \mathrm{~A}}$ receptor antagonists (e.g., SCH 58261 and ZM 241385) [255, 268, 300, 301] (Table 3; Fig. 3D), and not only $A_{1}$ receptor antagonists (e.g., CPT) [300] (Table 3) but also $A_{2 A}$ receptor agonists (e.g., CGS 21680) (Fig. 3C) [302] and $\mathrm{A}_{2 \mathrm{~A}}$ receptor antagonists (e.g., SCH 58261) [95] may also induce/enhance epileptic activity [140, 273-276, 303]. PTZ- and pilocarpine-induced seizures were reduced in $\mathrm{A}_{2 \mathrm{~A}}$ receptor knockout mice [304, 305]. In addition, for example, the $A_{2}$ selective ligand, 2phenylaminoadenosine (CV-1808), had no seizuredecreasing effect [267]. Nevertheless, excessive stimulation of $\mathrm{A}_{2 \mathrm{~A}}$ receptors in the brainstem may be involved in the pathomechanism of SUDEP (sudden unexpected death in epilepsy) [306, 307]. Rebola et al. [308] suggested that $\mathrm{A}_{2 \mathrm{~A}}$ receptor antagonists may be more promising anticonvulsant drugs than $\mathrm{A}_{1}$ agonists because they observed a long-term decrease and increase in $\mathrm{A}_{1}$ and $\mathrm{A}_{2 \mathrm{~A}}$ receptor density, respectively, after kindling- and kainic-acid-induced convulsion [308]. In addition, $A_{2 A}$ receptor antagonists may potentiate the neuroprotective effects of $A_{1}$ receptors [195]. Seizurepromoting modulatory effects on epileptic activity of $\mathrm{A}_{3}$ receptors have also been suggested. For example, the $A_{3}$ receptor antagonist MRS 1191 decreased the epileptiform activity [300] (Table 3; Fig. 3E).

The results described above suggest that purinergic mechanisms exhibit an ameliorating influence on various types of epilepsy via both antiseizure/antiepileptogenic effects. However, Ado and its receptors may have different roles in the modulation of different types of epilepsies. In addition, effects of Ado and Ado receptor agonists and antagonists may depend on the seizure model used (Table 3) and place/mode of drug application. For example, CGS 21680 was proconvulsant and anticonvulsant in three different animal models [95, 273, 276, 302]. Adenosine decreased or increased epileptic activity in PTZ- [118, 204], bicuculline- [117, 168], pilocarpine- [216], kainic-acid- [138], $\mathrm{Mg}^{2+}$-free [140, 219] and penicillin-induced models [120] as well as in the animal model of human absence epilepsy [309] (Table 4), and focally applied Ado was more effective against penicillin-induced epileptiform activity than intracerebroventricularly injected Ado [120]. In addition, Ado receptor agonists and antagonists as well as nucleoside transport inhibitors may have different effects on seizures in the mature brain compared with the immature brain because of (i) the level and distribution of endogenous Ado, (ii) the 
$A, A_{1}$ Ado receptor agonists

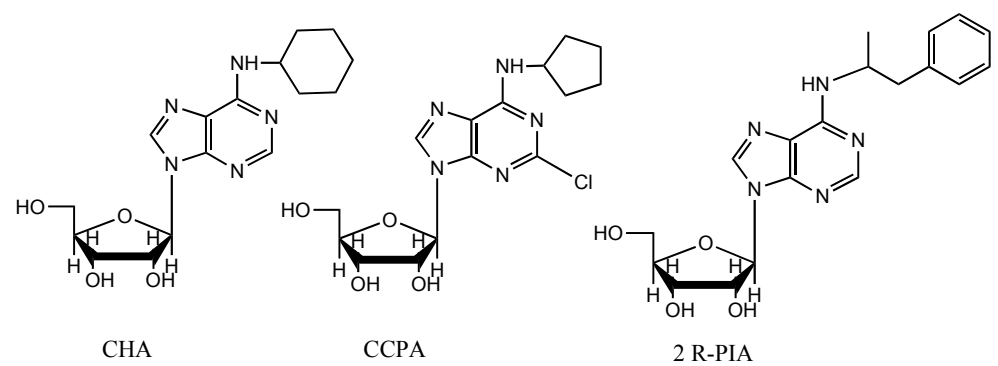

B, Non-selective Ado receptor agonist

$\mathrm{C}, \mathrm{A}_{2 \mathrm{~A}}$ Ado receptor agonist

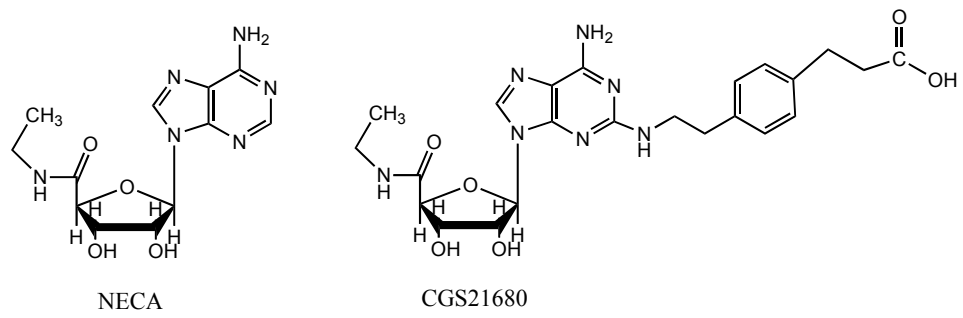<smiles>Nc1nc(NCCc2ccccc2)nc2nc(-c3ccco3)[nH]c12</smiles>

$\mathrm{D}, \mathrm{A}_{2 \mathrm{~A}}$ Ado receptor
antagonist

ZM241385
$\mathrm{E}, \mathrm{A}_{3}$ Ado receptor antagonist<smiles>CCOC(=O)C1=C(C)NC(c2ccccc2)=C(C(=O)OCc2ccccc2)C1C#Cc1ccccc1</smiles>

MRS1191

Fig. (3). The chemical structure of some drugs acting on adenosine receptors and used in epilepsy research. Abbreviations: CCPA: 2-chloro- $\mathrm{N}^{6}$ cyclopentyladenosine; CGS 21680: (2-(4-(2-carboxyethyl)-phenylamino)-5'-N-ethylcarboxamidoadenosine; CHA: $\mathrm{N}^{6}$-cyclohexyladenosine; MRS 1191: 3-ethyl-5-benzyl-2-methyl-4-phenylethynyl-6-phenyl-1,4-( \pm -dihydropyridine-3,5-dicarboxylate; NECA: 5'-(N-ethyl)carboxamidoadenosine; R-PIA: R-N 6 -(2-phenylisopropyl) adenosine; ZM 241385: 4-(2-[7-amino-2-[2-furyl]-[1,2,4] triazolo [2,3-a]\{1,3,5\}triazin-5-yl-amino] ethyl)phenol.

affinity of Ado receptors for Ado, (iii) the distribution of Ado receptors and Ado transporters and (iv) the ratio of different types of Ado receptors and, consequently, the physiological and pathophysiological role of Ado in different brain areas may be changed by age [31, 57, 310-313]. In addition, several other methodological circumstances, such as post mortem delay of brain tissue samples, age, gender, the species of experimental animals (subjects) and the type of solvent used, [30, 57, 314, 315] may modify the experimental results and effects of the applied drugs on epileptic seizures.

To obtain a complete antiepileptic profile of Ado and to reveal the exact modulatory effect of Ado and its analogs on different type of epilepsies, there is a need to investigate them in parallel in different in vivo and in vitro epilepsy models by similar methods (e.g., similar animal and slice models, as well as similar application mode/area of drugs, animal species and age of animals). In addition, Ado receptor (e.g., $\mathrm{A}_{1}$ ) agents, at least fully selective agonists, (i) cause numerous side effects, (ii) have low blood-brain barrier permeability and short halflife and (iii) may induce adaptive changes (such as receptor downregulation); thus, their clinical potential may be limited [118, 141, 256, 316-319]. However, partial agonists may prevent the desensitization [319], and, thus, their application in epilepsy may be more promising.

\subsubsection{Recently Developed Drugs Acting on the Adenosi- nergic System and Their Structure-activity Relationships}

Advances in medicinal chemistry and structure-activity relationships produced a large number of novel drugs acting on the adenosinergic system, a promising drug target for a variety of disorders including epilepsy. The newly developed drugs may have advantages over the older drugs such as higher potency, better selectivity, enhanced bioavailability and less toxicity. Although most of these drugs have not been investigated for their effects in epilepsy models, they represent promising future directions in this research field.

Different classes of non-nucleoside molecules were developed as inhibitors of ADK, such as pteridine-, pyrazoloand pyrido-pyrimidine-based inhibitors of ADK [320, 321]. ABT-702 (Fig. 4A), a pyridopyrimidine inhibitor demon- 
strated the highest potency among the orally available compounds [322]. Further structure-activity studies established that the 4-amino pyrimidine fragment and the aryl ring in the $\mathrm{C}(7)$ position are crucial pharmacophoric elements for pyridopyrimidines. However, although substances with higher in vitro potency have been produced, their in vivo efficacy remained suboptimal [323]. Coformycin and 2'-deoxycoformycin are outstandingly potent inhibitors of ADA. In fact, their almost irreversible blockage of ADA causes immunosuppressive side effects and toxicity. Nonetheless, crystallography revealed that the heterocyclic nitrogens do not form hydrogen bonds with the enzyme [324]. Instead, the heterocyclic ring interacted only with the $\mathrm{Zn}^{2+}$ ion in the active site, while the sugar hydroxyl groups formed hydrogen bonds with amino acids Asp 19 and His 117. Therefore, it was possible to develop less potent analogues containing the imidazo[4,5-e][1,2,4]triazepine ring system (Fig. 4B) by removing the ribose moiety [325]. While coformycin and 2'deoxycoformycin have been shown to act through so-called transition state inhibition of ADA, there are other modes of action, such as ground state inhibition of ADA. The structure of these drugs, including EHNA, resembles Ado, the endogenous substrate of the enzyme. Docking of EHNA to the ADA crystal structure revealed that the Ade $\mathrm{NH}_{2}$ group formed a hydrogen bond with Asp 295 and 296, while the 2'hydroxy group formed a hydrogen bond with the $\mathrm{N}$ hydrogen of His 17 and the S hydrogen of Cys 153 [326]. Modifications of the structure of EHNA using the 1- and 2-alkyl derivatives of the 4-aminopyrazolo[3,4-d]pyrimidine nucleus (Fig. 4C) also led to potent inhibitors of ADA [326]. Structure-based drug design and metabolic considerations led to the development of additional non-nucleoside ADA inhibitors (Fig. 4D) with oral bioavailability [327]. Molecular modeling simulations suggested that the imidazolecarboxamide and the hydroxyl group of this compound are at the same binding positions as the Ade and hydroxyl group of EHNA, while the 2,3-dichlorophenyl ring stabilizes the compound metabolically [327].

Another potential way of elevating the Ado level in the brain is by blocking SAHH. Following the crystallization of the enzyme, novel inhibitors were developed, including haloneplanocin A analogues [328], among which fluoroneplanocin A was found to be the most potent (Fig. 4E). Haloneplanocin $\mathrm{A}$ analogues exert their inhibition by being oxidized to their 3'-keto form by $\mathrm{NAD}^{+}$bound to $\mathrm{SAHH}$, thereby maintaining the co-factor permanently in its reduced form NADH. However, the low bioavailability of these products led to further research to find SAHH inhibitors. Based on the ability of the Red Sea sponge product, ilimaquinone, to inhibit SAHH [329], a new structural class of inhibitors of SAHH was developed (Fig. 4F). Structure-activity studies on these compounds also revealed that the quinine moiety of ilimaquinone serves as a ribose mimic [329].

ENTs are 11 transmembrane (TM) domain proteins with their $\mathrm{N}$-termini in the cytoplasm and the $\mathrm{C}$-termini in the $\mathrm{EC}$ space. Mutagenesis studies revealed that multiple TMs contribute to ENT function and that TMs 5 and 8 contain the largest number of operationally important residues [43]. Because the crystal structure of ENTs is not known, the structure of already available inhibitors was used for the rational design of novel inhibitors. Different classes of compounds were shown to inhibit ENTs present in the brain [330].
Modifications of NBTI, including LUF5942, were found to be potent inhibitors with lowered polar surface area [331]. The most potent and selective inhibitor of ENT1 is nitrobenzylmercaptopurine riboside (NBMPR) (Fig. 5A). Toxicity, selectivity and in vivo efficacy issues led to the development of some constrained analogues of NBMPR (Fig. 5B) as ENT1 inhibitors. The most suitable substitution position of the nitro group was explored by varying its position on the aromatic ring of the tetrahydroisoquinone moiety [332, 333]. In addition, novel fluorescent substrates have also been produced for probing transporter activity [334].

Mammalian CNTs contain at least 13, and possibly 15, TMs. Permeant selectivity, drug interactions and cation coupling are primarily located in the C-terminal half of the protein, especially TMs 7, 8, 11 and 12 [43]. In contrast to ENTs, CNTs demonstrate some substrate specificity [43, 335] (Table 1). CNT1 transports pyrimidine nucleosides and to some degree, Ado, CNT2 transports purine nucleosides and Urd, while CNT3 transports both classes with the ability to create a 10fold higher concentration gradient due to $2: 1 \mathrm{Na}^{+}$-nucleoside coupling, suggesting that it might play a role under special circumstances [336]. There are fewer compounds available for the inhibition of concentrative nucleoside transporters than for equilibrative nucleoside transporters. The most commonly used non-specific inhibitor of CNTs is phloridzin (Fig. 5C). Thus, recently developed non-nucleoside drugs for the inhibition of different classes of CNTs represent significant advances in the field by providing experimental tools for the involvement of these transporters in diseases including epilepsy [337]. The most potent selective inhibitor of CNT1 was a coumarin derivative (Fig. 5D), while the most active compound, which was selective for CNT3, was 6-hydroxy-7methoxyflavone (Fig. 5E). In addition, selective CNT2 inhibitors (Fig. 5F) have also been patented [338]. Structure-activity studies performed using the flavone structure pointed to significant differences between CNTs [337]. The flavone-binding site of CNT1 and CNT2 was quite stringent and that of CNT3 was tolerant in line with the lack of specificity of its nucleoside transport. Electrostatic interactions were dominant for all three CNTs, but hydrophobic interactions also played some role. In contrast, hydrogen-bonding interactions were important only for CNT2 and CNT3.

Drugs acting on Ado receptors have enormous potential in a variety of illness. Consequently, great efforts have been devoted to the medicinal chemistry of relevant compounds, which resulted in significant progress in the field [339]. In epilepsy, $A_{1}$ receptor agonists and $A_{2 A}$ receptor antagonists have the largest potential as therapeutic agents based on their inhibitory-excitatory activities and the abundance of these receptors in some brain regions. However, some data supports that antagonists acting on $\mathrm{A}_{2 \mathrm{~B}}$ receptors and agonists of $\mathrm{A}_{3}$ receptors may also have neuroprotective functions [340]. Furthermore, $\mathrm{A}_{1}$ receptor antagonists and $\mathrm{A}_{2 \mathrm{~A}}$ receptor agonists are also considered useful experimental tools. An issue in the development of drugs acting on Ado receptors is that the receptors demonstrate an unusually high species dependence. In particular, the affinity of drugs is often different in rodents and human [341]. Therefore, the results of animal experimentation have to be carefully interpreted. Another important point is the relatively fast desensitization of Ado receptors [342], which argues for the use or partial agonists in in vivo experiments. 


\section{A, ADK inhibitor}<smiles>Nc1ncnc2nc(-c3ccc(N4CCOCC4)nc3)cc(-c3cccc(Br)c3)c12</smiles>

ABT-702
B, ADA inhibitor<smiles>CCCOC1c2c(ncn2Cc2ccc(C)cc2)N=CN(C)N1C</smiles>

C, ADA inhibitor
D, ADA inhibitor<smiles>C[C@@H](O)[C@H](CCc1cccc(Cl)c1Cl)n1cnc(C(N)=O)c1</smiles>

E, SAHH inhibitor<smiles>Nc1ncnc2c1ncn2[C@@H]1C(F)=C(CO)[C@@H](O)[C@H](O)[C@@H]1O</smiles>

Fluoroneplanocin A

Fig. (4). The chemical structure of some drugs acting on enzymes potentially altering adenosine levels in the brain. Abbreviations: A: ABT702, a pyrido-pyrimidine inhibitor of ADK; B: an imidazo[4,5-e][1,2,4]triazepine type inhibitor of ADA; C: an 1- and 2-alkyl-4-aminopyrazolo[3,4-d]pyrimidine inhibitor of ADA; D: an ADA inhibitor 4-imidazolecarboxamide derivative; E: Fluoroneplanocin A, an SAHH inhibitor; F: a SAAH inhibitor ilimaquinone-adenosine hybrid.
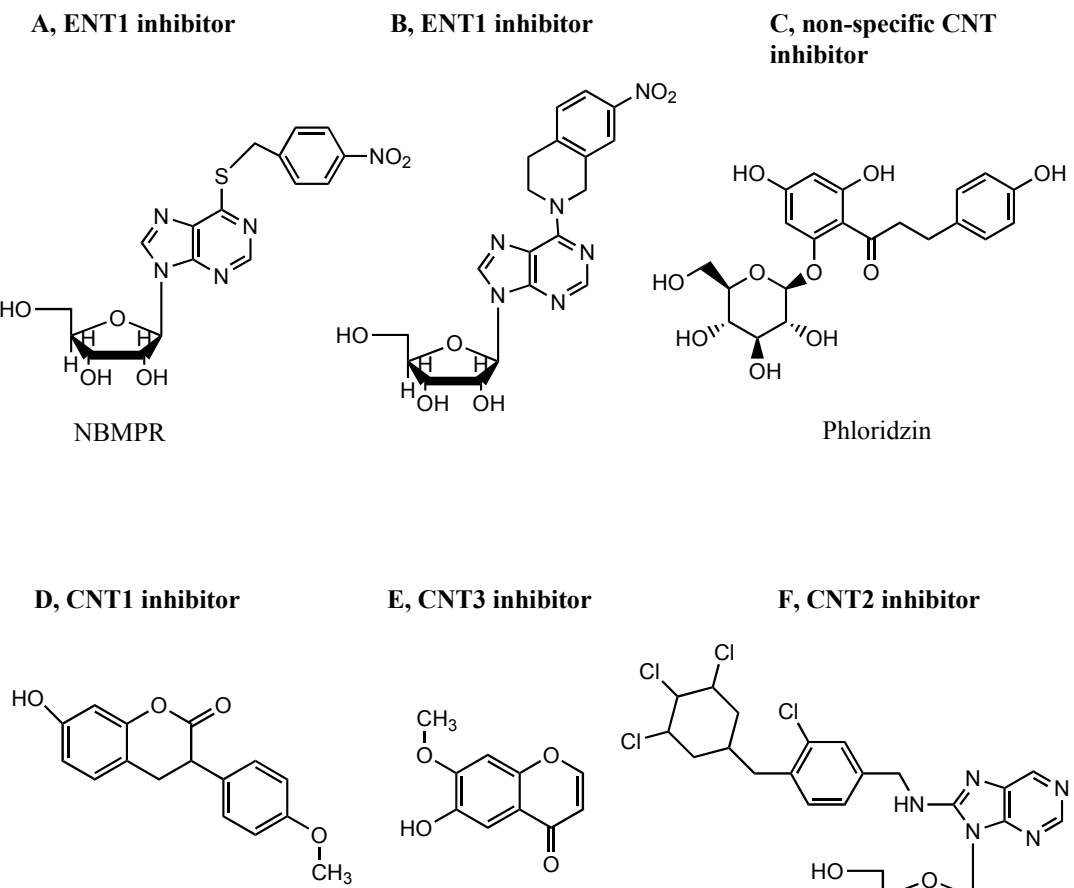<smiles>COc1cc2occc(=O)c2cc1O</smiles>

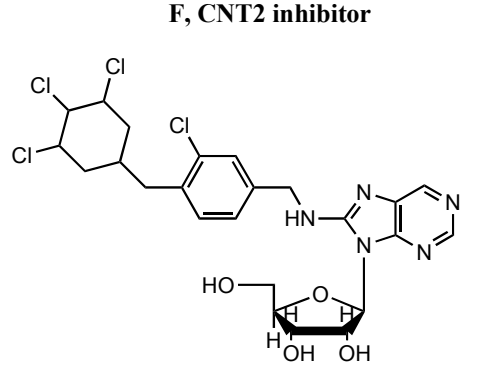

Fig. (5). The chemical structure of some recently developed drugs affecting nucleoside transporters. Abbreviations: A: NBMPR (nitrobenzylmercaptopurine riboside), the most established ENT1 inhibitor; B: a nitro-1,2,3,4-tetrahydroisoquinoline substituted derivative of NBMPR as an ENT1 inhibitor; C: Phloridzin is a non specific inhibitor of CNTs; D: a coumarin derivative as an inhibitor of CNT1: E: 6-hydroxy-7methoxyflavone is an inhibitor of CNT3; F: Purine nucleoside derivative modified in 8-position as an inhibitor of CNT2.

The pharmacology of the $A_{1}$ receptor has recently been reviewed [343]. Most $\mathrm{A}_{1}$ receptor agonists are $\mathrm{N}^{6}$-substituted Ado derivatives (e.g., selodenoson) (Fig. 6A). Another bene- ficial effect of $\mathrm{N}^{6}$-substitution is the escape from degradation by ADA. Recently, non-nucleoside 2-amino-3,5dicyanopyridine derivative $A_{1}$ receptor agonists (e.g., ca- 
padenoson) (Fig. 6B) were also developed. Furthermore, allosteric enhancers of the $A_{1}$ receptor were identified [344], of which an example is shown (Fig. 6C). Because the structure of the allosteric site is not known at the atomic level, subsequent structure-activity studies were performed, which demonstrated the importance of the 2-amino group of the 2amino-3-aroyl-thiophene moiety. Furthermore, electronwithdrawing substituents on the benzoyl moiety and alkyl and aryl groups in the 4- and 5-positions of the thiophene ring also promoted allosteric enhancement activity [344]. Adenosine receptor antagonists were originally developed by the modification of the caffeine (Xn) structure. There are still such $A_{1}$ receptors antagonists produced (e.g., L-97-1) (Fig. 6D). In general, modification of xanthines at the 8-position with aryl or cycloalkyl groups led to selectivity for the $A_{1}$ receptor. In addition, $A_{1}$ receptor antagonists with different structures, typically containing nonpurine heterocyclic core structures, have also been synthesized (e.g., FK-453) (Fig. 6E). Substitution of Ado at the 2-position, especially with (thio)ethers, secondary amines and alkynes, resulted in compounds selective for the $\mathrm{A}_{2 \mathrm{~A}}$ receptor.

Some $\mathrm{A}_{2 \mathrm{~A}}$ receptor agonists, including sonedenoson (Fig. 6F), have also been clinically evaluated [345]. However, hypotensive side effects hinder their therapeutic applications. $\mathrm{A}_{2 \mathrm{~A}}$ receptor antagonists (e.g., istradefylline) have been produced by the modification of xanthines at the 8-position with alkenes. In turn, very potent drugs, selective for the $A_{2 \mathrm{~A}}$ receptor were also developed by changing the heterocyclic structure (e.g., to triazolopyrimidine in vipadenant) (Fig. 6G). Selective $A_{2 B}$ receptor antagonists have also been developed [346]. PSB-1115 (Fig. 6H) is water-soluble and therefore appropriate for in vivo studies, although its affinity and selectivity is suboptimal compared to some other $A_{2 B}$ receptor antagonists.

The structure-activity relationship of drugs acting on the $\mathrm{A}_{3}$ receptor revealed that $\mathrm{N}^{6}$-benzyl and alkyl substituents favored binding to the $\mathrm{A}_{3}$ receptor [347]. The prototypical $\mathrm{A}_{3}$ receptor agonist is Cl-IB-MECA (Fig. 6I), which has a 2000fold affinity to the $\mathrm{A}_{3}$ compared to the $\mathrm{A}_{1}$ receptor. Cl-IBMECA, the currently available $A_{3}$ receptor agonist, is a nucleoside derivative [341].

\subsection{Non-adenosine Nucleosides: Uridine, Guanosine and Inosine}

Distribution of non-Ado nucleosides is also uneven in both the brain tissue and EC space $[30,56]$. Highest Ino $(101.5-161.5 \mathrm{pmol} / \mathrm{mg})$ and/or Guo $(19.5-26.1 \mathrm{pmol} / \mathrm{mg})$ and Urd (43.9-55.1 pmol/mg) levels were measured in the caudate nucleus, substantia innominata, nucleus basalis, cochlear nuclei, temporal cortex, occipital cortex and medial geniculate body in the human brain. The lowest concentrations of Ino (29.8-39.5 pmol/mg) and/or Guo (4.1-5.1 $\mathrm{pmol} / \mathrm{mg}$ ) and Urd (15.7-16.7 pmol/mg) have been demonstrated in the ventral anterior nucleus, habenula, zona incerta, paraventricular nucleus, preoptic area, inferior colliculus and locus coeruleus. Medium non-Ado nucleoside levels were found in the hippocampus (Ino/Guo/Urd, pmol/mg: 53.7/12.7/38.3) and cortical areas (except temporal and occipital cortex) in the human brain. Extracellular levels of Ino and Guo were regionally different in rat brain areas. Their concentrations in the rat striatum, hippocampus and thalamus were $1.50-2.00,0.42-1.37$ and $0.52 \mu \mathrm{M}$, respectively, for Ino and $0.50,0.26$ and $0.17 \mu \mathrm{M}$, respectively, for Guo. Concentrations of Urd were similar in the rat thalamus $(0.76 \mu \mathrm{M})$ and hippocampus $(0.71 \mu \mathrm{M})[112,123-126]$. Activity of PNP was intermediate to high in the cerebral cortex and thalamus [348], whereas intermediate levels of GDA activity were demonstrated in the hippocampus and parietal cortex of the human brain. The thalamus showed a high level of GDA [349]. Higher Ino levels in elderly rather than middle-aged human samples and higher non-Ado nucleoside (Urd, Ino and Guo) levels in female samples compared with male samples have also been demonstrated in cortical samples [57].

Nucleoside transporters may release/uptake not only Ado but also non-Ado nucleosides (Table 1); thus, the antiepileptic effect of nucleoside transporter inhibition may also be in relation to decreased uptake of Ino and/or Guo and Urd. Indeed, the anticonvulsant effect of Urd has been demonstrated. Uridine reduced penicillin-, bicuculline- and PTZinduced seizures and was effective in electroconvulsive models (Table 4) but did not protect against maximal electroshock-induced convulsions and 3-aminopyridine-induced seizures [112, 350-354]. However, it has been postulated that Urd may have a role in the initiation and termination of epileptic activity depending on its concentration [352]. More recently, Urd was found to be antiepileptogenic in hippocampal kindling models and in lithium-pilocarpine-induced status epilepticus in rats $[63,64]$. In addition, an increased Urd level was detected in 3-aminopyridine-(3-AP)-induced epileptic seizures, which most likely inhibits neuronal activity [112], and Urd reduces the firing rate of neurons in the hippocampus [59]. It has also been demonstrated by Dobolyi et al. [59] that Urd administration had no effect on the EC Ado concentration; thus, direct involvement of the adenosinergic system in an Urd-induced decrease in epileptic activity is not likely. However, indirect interaction between putative Urd receptors and Ado receptors has been demonstrated [83] as they may act together and result in anticonvulsant activity. Urd has been described to bind to a putative Urd receptor and the $\mathrm{GABA}_{\mathrm{A}}$ receptor $[83,84,90,354-356]$ suggesting that activation of both receptors by Urd may lead to a decrease in seizure susceptibility. As an increased Urd level may result in enhanced concentration of UTP [357] and UTP can change neuronal activity via its receptors [358], an indirect inhibitory effect of Urd on epileptic activity via UTP/UDP [76, 359] receptors can be postulated. However, UTP was ineffective in 4-aminopyridine (4-AP)-induced epileptiform activity [140]. Uridine has already been tested in human studies [360-364], and a decrease in seizure activity in response to Urd has been demonstrated in humans [363-365]. Uridine is also found in mother's milk and may be useful as a nutritional supplement during early postnatal development [366, 367]; consequently, Urd is a well tolerable drug, which showed low toxicity [63, 64, 360, 361]. These results suggest that Urd and/or its analogues [83, 356] may be effective and safe drugs to treat epilepsy [31].

Guanosine also has antiseizure effects in rodent epilepsy models, most likely via Guo-induced modulation of the glutamatergic system [60-62, 368-371]. Guo may bind to its putative (uncloned) G-protein-coupled receptors in the brain $[50,51]$. Guanosine levels increased after PTZ-induced 


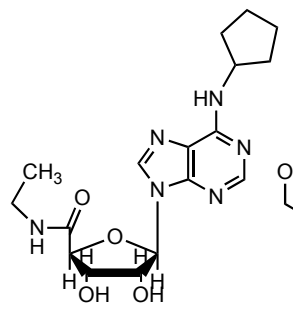

Selodenoson<smiles>OCCOc1ccccc1O</smiles>

enhancer

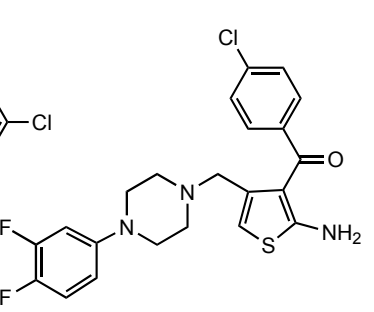

Capadenoson

$A_{1}$ receptor allosteric enhancer

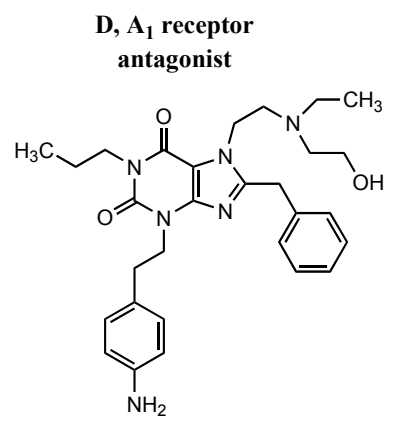

E, $A_{1}$ receptor

$F, A_{2 A}$ receptor agonist

antagonist

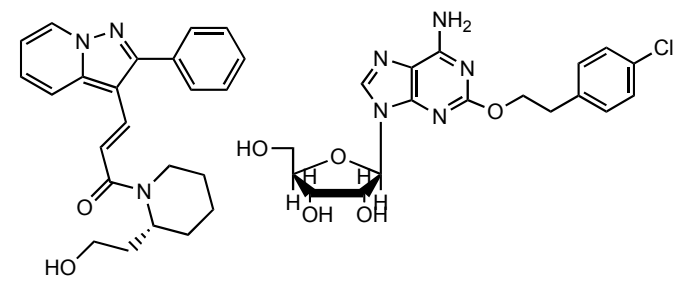

L-97-1

FK-453

Sonedenoson

$$
\begin{gathered}
\mathrm{G}, \mathrm{A}_{2 \mathrm{~A}} \text { receptor } \\
\text { antagonist }
\end{gathered}
$$
$\mathrm{H}, \mathrm{A}_{2 \mathrm{~B}}$ receptor antagonist

I, $A_{3}$ receptor agonist

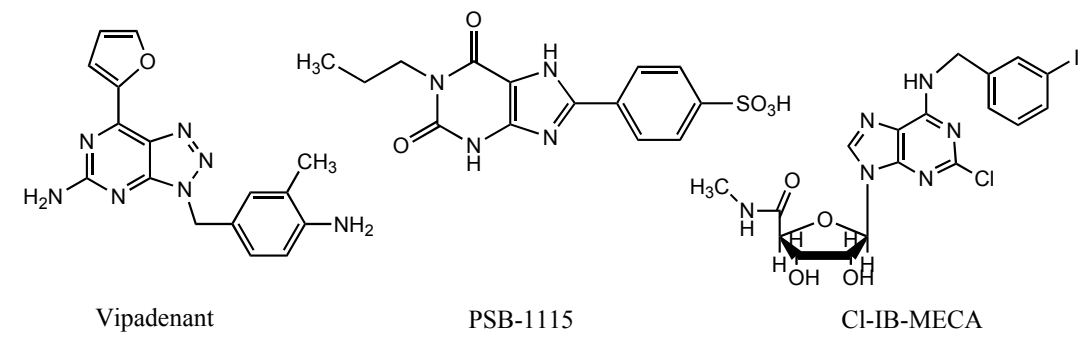

Fig. (6). The chemical structure of some recently developed agonists and antagonists of adenosine receptors. These compounds may be useful tools for further evaluation of adenosine actions in epilepsy. Abbreviations: A: Selodenoson is an $\mathrm{N}^{6}$-substituted adenosine derivatives $\mathrm{A}_{1}$ receptor agonist; B: Capadenoson, a derivative of 2-amino-3,5-dicyanopyridine is an $\mathrm{A}_{1}$ receptor agonist; C: a 2-amino-3-aroyl-4[(arylpiperazin-1-yl)methyl]thiophene allosteric agoinst of the $A_{1}$ receptor; D: L-97-1 is an $A_{1}$ receptor antagonist; E: FK-453 is an $A_{1}$ receptor antagonist containing a non-purine heterocyclic core; $\mathbf{F}$ : Sonedenoson is an $\mathrm{A}_{2 \mathrm{~A}}$ receptor agonists; $\mathbf{G}$ : Vipadenant is an $\mathrm{A}_{2 \mathrm{~A}}$ receptor antagonist; H: PSB-1115 is a selective $\mathrm{A}_{2 \mathrm{~B}}$ receptor antagonists; I: Cl-IB-MECA is the prototypical $\mathrm{A}_{3}$ receptor agonist.

seizures [372], and Guo exerts a protective effect on quinolinic acid (QA)-induced seizures [60-62, 368, 373-377] (Table 4) and $\alpha$-dendrotoxin-induced seizures [371] likely by stimulation of astrocytic glutamate uptake $[89,373,377$, 378]. It has been demonstrated that GMP- and GTP-induced decreases in seizures may be related to their conversion to Guo [89, 368, 375]. Involvement of the adenosinergic system in antiepileptic effects of Guo has been suggested because Guo induces stimulation of Ado release from astrocytes [379]. In addition, Guo, released mainly from astrocytes, stimulates astrocyte proliferation possibly via increased level of Ado [380, 381]. However, (i) intraperitoneal administration of Ado enhanced [309], (ii) an Ado receptor $\left(\mathrm{A}_{1}\right.$ and $\left.\mathrm{A}_{2}\right)$ antagonist (theophylline) decreased [382] and (iii) activation of $A_{2 \mathrm{~A}}$ receptor triggered/maintained [302] the absence epileptic activity in WAG/Rij rats. In addition, the involvement of the adenosinergic system in the Guo-induced decrease in QA-induced seizure activity was excluded [62, 89]. All of these data support the idea that the Guo-induced increase in Ado levels in the brain may not decrease epileptic activity, at least not in relation to absence epilepsy and QA-induced seizure activity. However, the modulatory role of the adenosinergic system appears to be different in different types of epilepsies (e.g., theophylline enhanced the epileptiform activity induced by bicuculline) [168]; thus, the additive antiepileptic effect of Guo and Ado in several epilepsy models (types) may not be fully explored. To summarize, Guo and/or its analogues may be potential antiepileptic drugs [62] because (i) Guo decreases glutamate concentration via upregulation of astrocytic glutamate uptake, consequently, (ii) Guo may shift the excitation/inhibition balance toward inhibition and (iii) Guo is a safe and well-tolerated drug for human use [62, 371, 383, 384].

During bicuculline-, kainic-acid-, PTZ- and electroshockinduced seizures and 3-AP-induced epilepsy $[112,372,385-$ 
388], as well as electrical or chemical depolarization [389], the level of the Ado metabolites Ino and/or Hyp were also increased. It has been demonstrated that Ino (i) increased the latency to PTZ-induced seizures [118, 390], (ii) antagonized caffeine-induced seizures [391], (iii) has a role in the electroshock-induced increase in the threshold to PTZ-induced seizures [387], (iv) had an anticonvulsant effect on QA-induced seizures [392] and (v) raised the threshold of seizures induced by PTZ, bicuculline and picrotoxin [58] (Table 4). Interestingly, a synthetic Hyp derivative, AIT-082 (4-[[3(1,6-dihydro-6-oxo-9-purin-9-yl)-1-

oxopropyl]amino]benzoic acid), may exert its neuroprotective effect against kainic-acid-induced status epilepticus (longer latency, shorter duration) partly via Ino [393]. Early increases in Ino levels may play a role in the generation and propagation of seizures, but subsequent elevation of Ino and/or Hyp concentration may be responsible for seizure termination [386, 394]. Inosine and/or Hyp may be endogenous ligands of benzodiazepine receptors [395-399] and the picrotoxin binding site [400] in the nervous system. Picrotoxin, PTZ and bicuculline are inhibitors of $\mathrm{GABA}_{\mathrm{A}}$ receptors (which may produce seizures), and this receptor also contains a benzodiazepine binding site [401]. Thus, benzodiazepine receptor ligands, such as diazepam [8] and likely Ino, may enhance GABA-mediated inhibition and may decrease seizure activity. It has been concluded that antiseizure/anticonvulsant effect of endogenous Ino [58] may correlate with its interaction with inhibitory $\mathrm{GABA}_{\mathrm{A}}$ receptors (benzodiazepine receptors) [386, 390, 399, 402]. Recently, it was discussed that Ino may also bind to Ado receptors $\left(\mathrm{A}_{1}\right.$, $\left.A_{2 A}, A_{3}\right)$ [403]; thus, the anticonvulsant effect of Ino may involve adenosinergic mechanisms as well. However, Ganzella et al. [392] demonstrated a decrease in seizures in response to Ino that was independent of the benzodiazepine and Ado receptors, which may involve Guo-induced astrocytic glutamate uptake [392]. Although (i) Ino binding site (binding to benzodiazepine receptors, to Ado receptors and/or to own specific Ino receptors, if any), (ii) interaction of Ino with other transmitter systems and (iii) modulators as well as exact signaling mechanism induced by Ino are not disclosed, these results suggest that Ino may also be a potential therapeutic agent in epilepsy.

\section{NEW DEVELOPMENTS}

Despite the ameliorating effect of ADK inhibition on epileptic seizures, side effects of systemic application of ADK inhibitors [93, 141] may limit their therapeutic use. In addition, systemic application of very high Ado doses may lead to astrogliosis-induced ADK expression and epileptic seizures; thus, focal application of Ado-releasing brain implants and in vivo gene therapies [67] may be a promising way to excite the anticonvulsant properties of Ado without severe side effects. In addition, a decrease in efficiency of the endogenous anticonvulsant Ado by efflux carriers via multidrug resistance-associated proteins is unlikely because of (i) the effective uptake mechanism of Ado via nucleoside transporters and (ii) the ADK-modulated Ado salvage mechanism, as described by Boison [65]. Direct administration of different drugs intraventricularly or intrathecally into the cerebrospinal fluid (CSF) would provide a solution for some of the problems regarding ADK inhibition. Admini- stration of drugs via catheters has both advantages (e.g., the total amount of injected drugs reach the brain) and disadvantages (e.g., penetration of drugs from CSF into brain tissue may be limited) [404].

To overcome the disadvantages concomitant with the direct infusion of drugs to CSF and to ensure the chronic delivery/long-term release of antiepileptic agents, Adoreleasing brain transplants (cells and polymers) were developed and applied. To enhance the Ado level and deliver it focally, intraventricular implantation of Ado-releasing (20$50 \mathrm{ng} /$ day) synthetic biocompatible polymer (ethylene vinyl acetate copolymers) was applied in kindled rats (Table 4) [114], and this treatment decreased the seizure activity. Adenosine-releasing silk-base polymers may be a more suitable strategy for drug delivery than synthetic polymers because of their biocompatibility and slow biodegradation, thus avoiding the need for removal of the synthetic polymer which limits their clinical application [33, 67, 405, 406]. Wilz et al. [407] developed silk-based polymers that release 0-1000 ng/day and 0-819 ng/day of Ado in vivo and in vitro, respectively. Based on kindled rats, which were intrahippocampally implanted with silk-based polymers, they concluded that approximately $1000 \mathrm{ng}$ /day Ado effectively decrease seizures, which could provide an opportunity for a safe decrease of epileptic seizures (Table 4) [407, 408]. These results suggest that focal synthetic-polymer-based and silk-based-polymer drug-delivery systems may release sufficient amounts of Ado to decrease epileptic activity. In addition, these systems may be safe without side effects.

Adenosine kinase may also be a therapeutic target for gene therapy [67, 409-416]. Downregulation of ADK, thus increasing Ado levels, by adeno-associated virus 8 (AAV8)mediated RNA interference (RNAi) in astrocytes (Table 4) $[413,414]$ and lentiviral RNAi-mediated downregulation of ADK in human mesenchymal stem cells [410-413] were developed by which the seizure activity was reduced in mice. In an encapsulated Ado-biodelivery cell system, the cells are (i) genetically modified (result in ADK deficiency, IC accumulation of Ado and Ado release) to synthesize and release a therapeutic dose of Ado and (ii) encapsulated (enclosed in semi-permeable membrane). A semi-permeable membrane prevents, for example, graft-cell-host-cell interactions and graft rejection, but permits the delivery of Ado to the surrounding cells [67]. Encapsulated Ado-releasing (e.g., approximately $19 \mathrm{ng} / \mathrm{h} / 10^{5}$ cells) [417] cells (fibroblasts, myoblasts, baby hamster kidney cells and mouse embryonic stem cells) were implanted intraventricularly. Focal Ado delivery, in the nanomolar range, by Ado-releasing encapsulated implants (i) effectively decreased the epileptic activity in the kindling model (Table 4) [113, 150, 416-421], (ii) did not cause receptor desensitization or central and peripheral side effects, such as sedation and hypothermia resulting from the equilibration of Ado levels by nucleoside transporters $[65,419]$, but (iii) usability may be restrained by limited long-term viability [67]. Implantation of Ado-releasing neuronal precursor cells into the rat hippocampus prior to kindling suppressed epileptogenesis (Table 4) [412, 422]. Intrahippocampal transplantation of Ado-releasing cells suppressed seizures in a kainic acid mouse model [165]. In addition, Ado accumulation, which may result in side effects, is precluded by EC metabolism of Ado by ecto-ADA [72, 75, 
76]. Despite these results, implantation of Ado-releasing cells has advantages (e.g., there is no need to refill the system as with pumps and polymers) and disadvantages (e.g., the lack of control of drug release and the unknown longterm effects) [404].

All of these promising preclinical results suggest that implantation of biodegradable Ado-releasing polymers and cells as well as gene therapy may be a safe and effective tool for the prevention and treatment of epileptogenesis and epilepsy via increasing Ado levels through the activation of mainly $\mathrm{A}_{1}$ receptors. However, before clinical application of Ado augmentation therapy [67] new findings are needed, such as conclusive demonstration of (i) therapeutic index, (ii) long-term efficacy and (iii) usability in different types of epilepsies.

Although the binding and signaling mechanism of nonAdo nucleosides (Urd, Guo and Ino) as well as their exact effect on epileptic activity have not been established yet, the available data suggest an expansion of the adenosinergic/purinergic hypothesis in relation to epileptic activity [93, 423]; therefore, we discussed that not only Ado but also endogenous Urd, Guo and Ino might have a crucial role in the modulation of the epileptic activity and sensitivity to epileptic seizures. Consequently, even if we have only sporadic data on the distribution and function of metabolic enzymes of Urd, Guo and Ino under different pathological conditions (e.g., epilepsy) in brain areas, we cannot exclude the possibility that their metabolic enzyme inhibitors are potential antiepileptic drugs, which increase the levels of non-Ado nucleosides. In addition, analogues of Ado-releasing implants, including Urd-, Guo- and Ino-releasing implants, may also be effective antiepileptic approaches. Silk fibroin encapsulation [406] may be a usable method to test this hypothesis. However, more detailed studies are necessary to reveal this novel possibility. In addition, the anti-inflammatory effects of not only Ado [197, 198, 201, 424] but also of Urd and Ino have been demonstrated [403, 424-426]; thus, investigation of the effect of Urd and Ino on inflammationinduced exacerbation of epileptic activity [192, 193] may also be an interesting and promising novel drug discovery target in epilepsy research.

\section{SUMMARY AND PERSPECTIVES}

It has been demonstrated that impaired Ado-mediated inhibition may correlate with epilepsy. Adenosine and its metabolic enzymes, receptors and nucleoside transporters are unevenly distributed in the brain. In addition, Ado (i) is released under seizure activity, (ii) inhibits neuronal and seizure activity, (iii) increases seizure threshold, (iv) terminates seizures and $(\mathrm{v})$ prevents the spreading of seizures via its receptors (mainly by $A_{1}$ receptors). These results suggest that Ado is an endogenous anticonvulsant/antiepileptogenic modulator, and purinergic mechanisms may be involved in the pathomechanism of the seizures.

Because seizure-induced increases in the endogenous anticonvulsant Ado levels result in decreased epileptic activity via activation of Ado receptors, Ado-based antiepileptic therapies are currently under development. Application of (i) Ado receptor agonists, (ii) Ado receptor antagonist, (iii) nucleoside transporter inhibitors, as well as (iv) the modulation of Ado metabolism (e.g., by ADK inhibitors) and (v) implantation of Ado-releasing cells/polymers may also be useful methods to therapeutically increase the level of the endogenous antiepileptic agent Ado and enhance Ado signaling. However, Ado receptor agonists and antagonists as well as ADK inhibitors may cause severe side effects, and Adoreleasing polymers have also several disadvantage. Conclusively, implantation of Ado-releasing stem cells/neuronal progenitor cells may be a more effective and attractive option to decrease epileptic activity, including in pharmacoresistant types of epilepsies, without the induction of severe side effects.

Because of the limited efficacy of antiepileptic therapy, approximately one third of epileptic patients are refractory to the available antiepileptic drugs, and the treatment of their epileptic syndromes remains unsolved. Thus, finding safe and well-tolerated drugs, such as Ado, Urd, Ino and Guo or other endogenous molecules (by which serious side effects may well be avoidable), or developing their analogues remains a high priority and a great need in epilepsy research. All available evidence suggests that the enhancement of endogenous antiepileptic mechanisms by increasing nucleoside levels in the brain may be a safe and effective therapeutic approach for the treatment of epilepsy. This review article presented literature data supporting the notion that not only Ado but also Urd, Ino and Guo, (i) may play important roles as endogenous anticonvulsant signaling/modulator molecules and (ii) may represent new pharmacological tools to treat different types of epilepsies. However, all drugs, which exert their effects on the purinome, affected receptors or changed nucleoside levels by acting on transporters and metabolic enzymes of the purinergic system [427] induced both ameliorating effects and pathological changes in the CNS. Thus, further studies are necessary (i) to reveal the exact effects of endogenous nucleosides and their analogues on the epileptic activity, (ii) to identify specific receptors of Urd, Ino and Guo (if any) and to disclose their signal transduction mechanisms, (iii) to explore the therapeutic indexes of nucleosides and their safety profiles (with emphasis on the relatively neglected nucleosides Urd, Ino and Guo as opposed to Ado), (iv) to test nucleoside-releasing implants (e.g., half-life, metabolism, storage and absorption of nucleosides) and (v) to investigate these promising therapeutic tools in both in vivo and in vitro models of different types of epilepsies under similar conditions before clinical application.

\section{CONFLICT OF INTEREST}

The author(s) confirm that this article content has no conflicts of interest.

\section{ACKNOWLEDGEMENTS}

This work was supported by the National Development Agency of Hungary (under Grant No. TIOP-1.3.1.-07/2-2F2009-2008) (Zsolt Kovács), TÁMOP 4.2.1./B-09/1/KMR2010-0003 (Gábor Juhász and Katalin Adrienna Kékesi) and the OTKA K100319 Research Grant and the KTIA NAP B Program as well as the Bolyai János Fellowship Grant of the Hungarian Academy of Sciences (Árpád Dobolyi). We wish to thank László Héja for help in the preparation of (Figs. 26). 


\section{ABBREVIATIONS}

2-CLA

2-HE-NECA

3-AP

5'NT

$\mathrm{A}_{1}$ receptor

$\mathrm{A}_{2 \mathrm{~A}}$ receptor

$\mathrm{A}_{2 \mathrm{~B}}$ receptor

$\mathrm{A}_{3}$ receptor

A-286501

ABT-702

ACSF

ADA

Ade

ADK

Ado

AMP

AMPDA

APCP

APNEA

APRT

ASL

ASS

ATP

CCPA

CGS 21680

CHA

Cl-IB-MECA

$\mathrm{cN}$

CNS

$\mathrm{CNT}$ transporters =

$=$

CNT1/T2/T3 transporters

$=$
CPA

CPCA

CPT

mido-adenosine

$=3$-aminopyridine

$=5$ '-nucleotidases

$=\quad \mathrm{A}_{1}$ subtype of adenosine receptors

$=\quad \mathrm{A}_{2 \mathrm{~A}}$ subtype of adenosine receptors

$=\quad \mathrm{A}_{2 \mathrm{~B}}$ subtype of adenosine receptors

$=\quad \mathrm{A}_{3}$ subtype of adenosine receptors

$=\quad \mathrm{N} 7-\left(\left(1^{\prime} \mathrm{R}, 2^{\prime} \mathrm{S}, 3^{\prime} \mathrm{R}, 4^{\prime} \mathrm{S}\right)-2^{\prime}, 3^{\prime}-\right.$ dihydroxy-4'-amino-cyclopentyl)4-amino-5-bromo-pyrrolo[2,3a]pyrimidine

$=$ 4-amino-5-(3-bromophenyl)-7-(6morpho linopyridin-3-yl)pyrido[2, 3-d] pyrimidine

$=$ Artificial cerebrospinal fluid

$=\quad$ Adenosine deaminase

$=$ Adenine

$=\quad$ Adenosine kinase

$=$ Adenosine

$=$ Adenosine monophosphate

$=\quad \mathrm{AMP}$ deaminase

$=\quad \alpha, \beta$-methyleneadenosine-5'diphosphate

$=\quad \mathrm{N}^{6}$-2-(4-aminophenyl) ethyladeno sine

$=$ Adenine phosphoribosyltransferase

$=$ Adenylosuccinate lyase

$=$ Adenylosuccinate synthetase

$=$ Adenosine triphosphate

$=2$-chloro- $\mathrm{N}^{6}$-cyclopentyl-adenosine

$=\quad$ (2-(4-(2-carboxyethyl)-phenyla mino)-5'-N-ethylcarboxamidoadenosine

$=\quad \mathrm{N}^{6}$-cyclohexyl-adenosine

2-chloro-N6-(3-iodobenzyl)adenosine-5'-N-methylcarboxa mide

$=\quad$ Cytoplasmic 5'-nucleotidases

Central nervous system

Concentrative nucleoside transporters

CNT1/CNT2/CNT3 subtype of porters

CSF

DHU

DPD

D-PIA

EHNA

GDA

GFAP

GMP

GMPS

Gn

GP683

GTP

Guo

IC

IL-1 $\beta$

IMP

Ino

L-PIA $=\quad \mathrm{N}^{6}$-cyclopentyl-adenosine

$=\quad 5^{\prime}$-(N-cyclopropyl)-carboxamidoadenosine

$=8$-cyclopentyl-1,3-dimethylxan thine

CV-1808

Cerebrospinal fluid

$=2$-phenylaminoadenosine

$=$ Dihydrouracil

$=$ Dihydropyrimidine dehydrogenase

$=\quad \mathrm{D}-\mathrm{N}^{6}-(2-$ phenylisopropyl $)$ adenosine

EC $\quad=\quad$ Extracellular

$=$ Erythro-9-(2-hydroxy-3-nonyl) adenine

"ei" transporters = Equilibrative, NBTI insensitive type of ENTs

ENT transporters $=$ Equilibrative nucleoside transporters

ENT1/T2/T3/T4 transporters ENT1/ENT2/ENT3/ENT4 subtype of equilibrative nucleoside transporters

"es" transporters = Equilibrative, NBTI sensitive type of ENTs

GABA $=$ Gamma amino butyric acid

GMPR

HGPRT

$=$ Guanine deaminase

$=\quad$ Glial fibrillary acidic protein

$=$ Guanosine monophosphate

$=$ GMP reductase

$=\quad$ GMP synthetase

$=$ Guanine

$=\quad 4-(\mathrm{N}-$ phenylamino $)-5$-phenyl-7(5'-deoxyribofuranosyl)pyrrolo [2,3-d]pyrimidine

$=$ Guanosine triphosphate

$=$ Guanosine

$=$ Hypoxanthine phosphoribosyltransferase (hypoxanthine-guanine phosphoribosyltransferase)

Hyp = Hypoxanthine

IMPDH

$=$ Intracellular

$=$ Interleukin- $1 \beta$

$=$ Inosine monophosphate

$=$ IMP dehydrogenase

$=$ Inosine

$=\quad \mathrm{L}-\mathrm{N}^{6}-(2-$ phenylisopropyl $)$ adenosine

LPS

Lipopolysaccharide 


$\begin{array}{lll}\text { NBMPR } & = & \text { Nitrobenzylmercaptopurine ri- } \\ \text { NBTI } & = & \text { S-(4-nitrobenzyl)-6-thioinosine } \\ \text { NECA } & = & 5 \text {-(N-ethyl)carboxamidoadeno } \\ \text { Nine } & \text { N-methyl-D-aspartate receptor } \\ \text { PNP } & = & \text { Purine nucleoside phosphorylase } \\ \text { PRPP } & = & \text { 5-phosphoribosyl-1-pyrophos } \\ \text { PTZ } & = & \text { Phate } \\ \text { QA } & = & \text { Quinolinic acid } \\ \text { RNAi } & = & \text { RNA interference } \\ \text { R-PIA } & = & \text { R-N }{ }^{6}-(2-\text { phenylisopropyl) adeno- } \\ \text { sine } & \text { S-adenosylhomocysteine } \\ \text { SAH } & = & \text { Adenosylhomocysteinase } \\ \text { SAHH } & = & \text { adenosylhomocysteine hydrolase) } \\ \text { SCH 58261 } & = & \text { X-amino-7-(2-phenylethyl)-2-(2- } \\ \text { furyl)-pyrazolo-(4,3-c)1,2,4- } & \text { Xanthine oxidase } \\ \text { S-PIA } & = & \text { S-N }\end{array}$

\section{REFERENCES}

[1] Ure, J.A.; Perassolo, M. Update on the pathophysiology of the epilepsies. J. Neurol. Sci., 2000, 177(1), 1-17.

[2] Avoli, M.; Louvel, J.; Pumain, R.; Köhling, R. Cellular and molecular mechanisms of epilepsy in the human brain. Prog. Neurobiol., 2005, 77(3), 166-200.

[3] Giblin, K.A.; Blumenfeld, H. Is epilepsy a preventable disorder? New evidence from animal models. Neuroscientist, 2010, 16(3), 253-275.

[4] Lin, J.J.; Mula, M.; Hermann, B.P. Uncovering the neurobehavioural comorbidities of epilepsy over the lifespan. Lancet, 2012, 380(9848), 1180-1192.

[5] Avanzini, G.; Franceschetti, S. Cellular biology of epileptogenesis. Lancet Neurol., 2003, 2(1), 33-42.

[6] Badawy, R.A.; Harvey, A.S.; Macdonell, R.A. Cortical hyperexcitability and epileptogenesis: Understanding the mechanisms of epilepsy - part 2. J. Clin. Neurosci., 2009, 16(4), 485-500.
[7] Badawy, R.A.; Harvey, A.S.; Macdonell, R.A. Cortical hyperexcitability and epileptogenesis: understanding the mechanisms of epilepsy - part 1.J. Clin. Neurosci., 2009, 16(3), 355-365.

[8] Treiman, D.M. GABAergic mechanisms in epilepsy. Epilepsia, 2001, 42(Suppl 3), 8-12.

[9] WHO. Fact sheet N 999 January, 2009; http://www.who.int/ mediacentre/factsheets/fs999/en/

[10] Löscher, W.; Luna-Tortós, C.; Römermann, K.; Fedrowitz, M. Do ATP-binding cassette transporters cause pharmacoresistance in epilepsy? Problems and approaches in determining which antiepileptic drugs are affected. Curr. Pharm. Des., 2011, 17(26), 2808-2828.

[11] Löscher, W.; Potschka, H. Role of multidrug transporters in pharmacoresistance to antiepileptic drugs. J. Pharmacol. Exp. Ther., 2002, 301(1), 7-14.

[12] Sisodiya, S.M.; Lin, W.R.; Harding, B.N.; Squier, M.V.; Thom, M. Drug resistance in epilepsy: expression of drug resistance proteins in common causes of refractory epilepsy. Brain, 2002, 125(Pt 1), 22-31.

[13] Biagini, G.; Marinelli, C.; Panuccio, G.; Puia, G.; Avoli, M. GliaNeuron Interactions: Neurosteroids and Epileptogenesis. In: Jasper's Basic Mechanisms of the Epilepsies [Internet]; Noebels, J.L.; Avoli, M.; Rogawski. M.A.; Olsen, R.W; Delgado-Escueta, A.V., Eds.; Bethesda (MD): National Center for Biotechnology Information (US), 2012; 4th edition; Available from: http:// www.ncbi.nlm.nih.gov/books/NBK98132/

[14] Yalçın, O. Genes and molecular mechanisms involved in the epileptogenesis of idiopathic absence epilepsies. Seizure, 2012, 21(2), 79-86.

[15] Avoli, M. A brief history on the oscillating roles of thalamus and cortex in absence seizures. Epilepsia, 2012, 53(5), 779-789.

[16] Coenen, A.M.; Van Luijtelaar, E.L. Genetic animal models for absence epilepsy: a review of the WAG/Rij strain of rats. Behav. Genet., 2003, 33(6), 635-655.

[17] Pitkänen, A.; Lukasiuk, K. Mechanisms of epileptogenesis and potential treatment targets. Lancet Neurol., 2011, 10(2), 173-186.

[18] Pitkänen, A.; Lukasiuk, K. Molecular and cellular basis of epileptogenesis in symptomatic epilepsy. Epilepsy Behav., 2009, 14(Suppl 1), 16-25.

[19] Pitkänen, A. Therapeutic approaches to epileptogenesis-hope on the horizon. Epilepsia, 2010, 51(Suppl 3), 2-17.

[20] Margineanu, D.G. Systems biology impact on antiepileptic drug discovery. Epilepsy Res., 2012, 98(2-3), 104-115.

[21] Howard, P.; Twycross, R.; Shuster, J.; Mihalyo, M.; Rémi, J.; Wilcock, A. Anti-epileptic drugs. J. Pain Symptom Manage., 2011, 42(5), 788-804.

[22] Perucca, P.; Gilliam, F.G. Adverse effects of antiepileptic drugs. Lancet Neurol., 2012, 11(9), 792-802.

[23] Burnstock, G. Physiology and pathophysiology of purinergic neurotransmission. Physiol. Rev., 2007, 87(2), 659-797.

[24] Burnstock, G.; Fredholm, B.B.; Verkhratsky, A. Adenosine and ATP receptors in the brain. Curr. Top. Med. Chem., 2011, 11(8), 973-1011.

[25] Huang, Z.L.; Urade, Y.; Hayaishi, O. The role of adenosine in the regulation of sleep. Curr. Top. Med. Chem., 2011, 11(8), 10471057.

[26] Boison, D. Adenosine as a neuromodulator in neurological diseases. Curr. Opin. Pharmacol., 2008, 8(1), 2-7.

[27] Boison, D. The adenosine kinase hypothesis of epileptogenesis. Prog. Neurobiol., 2008, 84(3), 249-262.

[28] Boison, D.; Singer, P.; Shen, H.Y.; Feldon, J.; Yee, B.K. Adenosine hypothesis of schizophrenia--opportunities for pharmacotherapy. Neuropharmacology, 2012, 62(3), 1527-1543.

[29] Fields, R.D.; Burnstock, G. Purinergic signalling in neuron-glia interactions. Nat. Rev. Neurosci., 2006, 7(6), 423-436.

[30] Kovacs, Z.; Juhász, G.; Palkovits, M.; Dobolyi, A.; Kékesi, K.A. Area, age and gender dependence of the nucleoside system in the brain: a review of current literature. Curr. Top. Med. Chem., 2011, 11(8), 1012-1033.

[31] Kovacs, Z.; Dobolyi, A. Anatomical distribution of nucleoside system in the human brain and implications for therapy. In: Adenosine: a key link between metabolism and brain activity; Masino, S.A.; Boison, D., Eds.; Springer Science, Business Media: New York, 2013; pp. 621-656.

[32] Lopes, L.V.; Sebastiao, A.M.; Ribeiro, J.A. Adenosine and related drugs in brain diseases: present and future in clinical trials. Curr. Top. Med. Chem., 2011, 11(8), 1087-1101. 
[33] Boison, D.; Stewart, K.A. Therapeutic epilepsy research: from pharmacological rationale to focal adenosine augmentation. Biochem. Pharmacol., 2009, 78(12), 1428-1437.

[34] Da Silveira, V.G.; da Silva, R.S.; de Paula Cognato, G.; Capiotti, K.M.; Figueiró, F.; Bogo, M.R.; Bonan, C.D.; Perry, M.L.; Battastini, A.M. A ketogenic diet did not prevent effects on the ectonucleotidases pathway promoted by lithium-pilocarpine-induced status epilepticus in rat hippocampus. Metab. Brain Dis., 2012, 27(4), 471-478.

[35] Camici, M.; Micheli, V.; Ipata, P.L.; Tozzi, M.G. Pediatric neurological syndromes and inborn errors of purine metabolism. Neurochem. Int., 2010, 56(3), 367-378.

[36] Löffler, M.; Fairbanks, L.D.; Zameitat, E.; Marinaki, A.M.; Simmonds, H.A. Pyrimidine pathways in health and disease. Trends Mol. Med., 2005, 11(9), 430-437.

[37] Nyhan, W.L. Disorders of purine and pyrimidine metabolism. Mol. Genet. Metab., 2005, 86(1-2), 25-33.

[38] Micheli, V.; Camici, M.; Tozzi, M.G.; Ipata, P.L.; Sestini, S.; Bertelli, M.; Pompucci, G. Neurological disorders of purine and pyrimidine metabolism. Curr. Top. Med. Chem., 2011, 11(8), 923947.

[39] Allsop, J.; Watts, R.W.E. Purine de novo synthesis in liver and developing rat brain, and the effect of some inhibitors of purine nucleotide interconversion. Enzyme, 1983, 30(3), 172-180.

[40] Ipata, P.L. Origin, utilization, and recycling of nucleosides in the central nervous system. Adv. Physiol. Educ., 2011, 35(4), 342-346.

[41] Ipata, P.L.; Camici, M.; Micheli, V.; Tozzi, M.G. Metabolic network of nucleosides in the brain. Curr. Top. Med. Chem., 2011, 11(8), 909-922.

[42] Giuliani, P.; Ballerini, P.; Ciccarelli, R.; Buccella, S.; Romano, S.; D'Alimonte, I.; Poli, A.; Beraudi, A.; Peña, E.; Jiang, S.; Rathbone, M.P.; Caciagli, F.; Di Iorio, P. Tissue distribution and metabolism of guanosine in rats following intraperitoneal injection. J. Biol. Regul. Homeost. Agents, 2012, 26(1), 51-65.

[43] Parkinson, F.E.; Damaraju, V.L.; Graham, K.; Yao, S.Y.M.; Baldwin, S.A.; Cass, C.E.; Young, J.D. Molecular biology of nucleoside transporters and their distributions and functions in the brain. Curr. Top. Med. Chem., 2011, 11(8), 948-972.

[44] Wall, M.J.; Dale, N. Auto-inhibition of rat parallel fibre-Purkinje cell synapses by activity-dependent adenosine release. J. Physiol., 2007, 581(Pt 2), 553-565.

[45] Wall, M.; Dale, N. Activity-dependent release of adenosine: a critical re-evaluation of mechanism. Curr. Neuropharmacol., 2008, 6(4), 329-337.

[46] Klyuch, B.P.; Dale, N.; Wall, M.J. Deletion of ecto-5'-nucleotidase (CD73) reveals direct action potential-dependent adenosine release. J. Neurosci., 2012, 32(11), 3842-3847.

[47] Dale, N.; Frenguelli, B.G. Release of adenosine and ATP during ischemia and epilepsy. Curr. Neuropharmacol., 2009, 7(3), 160179.

[48] Latini, S.; Pedata, F. Adenosine in the central nervous system: release mechanisms and extracellular concentrations. J. Neurochem., 2001, 79(3), 463-484.

[49] Fredholm, B.B.; Vernet, L. Release of 3H-nucleosides from 3Hadenine labelled hypothalamic synaptosomes. Acta Physiol. Scand., 1979, 106(2), 97-107.

[50] Traversa, U.; Bombi, G.; Camaioni, E.; Macchiarulo, A.; Costantino, G.; Palmieri, C.; Caciagli, F.; Pellicciari, R. Rat brain guanosine binding site. Biological studies and pseudo-receptor construction. Bioorg. Med. Chem., 2003, 11(24), 5417-5425.

[51] Volpini, R.; Marucci, G.; Buccioni, M.; Dal Ben, D.; Lambertucci, C.; Lammi, C.; Mishra, R.C.; Thomas, A.; Cristalli, G. Evidence for the existence of a specific g protein-coupled receptor activated by guanosine. Chem. Med. Chem., 2011, 6(6), 1074-1080.

[52] Dobolyi, A.; Juhász, G.; Kovacs, Z.; Kardos, J. Uridine function in the central nervous system. Curr. Top. Med. Chem., 2011, 11(8), 1058-1067.

[53] Kékesi, K.A.; Kovacs, Zs.; Szilágyi, N.; Bobest, M.; Szikra, T.; Dobolyi, Á.; Juhász, G.; Palkovits, M. Concentration of nucleosides and related compounds in cerebral and cerebellar cortical areas and white matter of the human brain. Cell. Mol. Neurobiol., 2006, 26(4-6), 833-844.

[54] Kovacs, Zs.; Dobolyi, Á.; Szikra, T.; Palkovits, M.; Juhász, G. Uneven regional distribution of nucleotide metabolism in human brain. Neurobiology (Bp), 1998, 6(3), 315-321.
[55] Kovacs, Z.; Kékesi, K.A.; Bobest, M.; Török, T.; Szilágyi, N.; Szikra, T.; Szepesi, Zs.; Nyilas, R.; Dobolyi, Á.; Palkovits, M.; Juhász, G. Post mortem degradation of nucleosides in the brain: comparison of human and rat brains for estimation of in vivo concentration of nucleosides. J. Neurosci. Methods, 2005, 148(1), 8893.

[56] Kovacs, Z.; Dobolyi, Á.; Juhász, G.; Kékesi, A.K. Nucleoside map of the human central nervous system. Neurochem. Res., 2010, 35(3), 452-464.

[57] Kovacs, Z.; Juhász, G.; Dobolyi, Á.; Bobest, M.; Papp, V.; Takáts, L.; Kékesi, K.A. Gender- and age-dependent changes in nucleoside levels in the cerebral cortex and white matter of the human brain. Brain. Res. Bull., 2010, 81(6), 579-584.

[58] Lewin, E.; Bleck, V. Effect of inosine on seizures induced with pentylenetetrazole, bicuculline, or picrotoxin. Epilepsia, 1985, 26(3), 258-261.

[59] Dobolyi, Á.; Szikra, T.; Kékesi, A.K.; Kovacs, Z.; Juhász, G. Uridine is released by depolarization and inhibits unit activity in the rat hippocampus. Neuroreport, 1999, 10(14), 3049-3053.

[60] De Oliveira, D.L.; Horn, J.F.; Rodrigues, J.M.; Frizzo, M.E.; Moriguchi, E.; Souza, D.O.; Wofchuk, S. Quinolinic acid promotes seizures and decreases glutamate uptake in young rats: reversal by orally administered guanosine. Brain Res., 2004, 1018(1), 48-54.

[61] Schmidt, A.P.; Lara, D.R.; De Faria Maraschin, J.; Da Silveira Perla, A.; Onofre Souza, D. Guanosine and GMP prevent seizures induced by quinolinic acid in mice. Brain Res., 2000, 864(1), 4043.

[62] Lara, D.R.; Schmidt, A.P.; Frizzo, M.E.; Burgos, J.S.; Ramírez, G.; Souza, D.O. Effect of orally administered guanosine on seizures and death induced by glutamatergic agents. Brain Res., 2001, 912(2), 176-180.

[63] Zhao, Q.; Marolewski, A.; Rusche, J.R.; Holmes, G.L. Effects of uridine in models of epileptogenesis and seizures. Epilepsy Res., 2006, 70(1), 73-82.

[64] Zhao, Q.; Shatskikh, T.; Marolewski, A.; Rusche, J.R.; Holmes, G.L. Effects of uridine on kindling. Epilepsy Behav., 2008, 13(1), 47-51.

[65] Boison, D. Adenosine and epilepsy: from therapeutic rationale to new therapeutic strategies. Neuroscientist, 2005, 11(1), 25-36.

[66] Boison, D. Adenosine kinase, epilepsy and stroke: mechanisms and therapies. Trends Pharmacol. Sci., 2006, 27(12), 652-658.

[67] Boison, D. Adenosine augmentation therapies (AATs) for epilepsy: prospect of cell and gene therapies. Epilepsy Res., 2009, 85(2-3), $131-141$.

[68] Hamil, N.E.; Cock, H.R.; Walker, M.C. Acute down-regulation of adenosine $\mathrm{A}(1)$ receptor activity in status epilepticus. Epilepsia, 2012, 53(1), 177-188.

[69] Lovatt, D.; Xu, Q.; Liu, W.; Takano, T.; Smith, N.A.; Schnermann, J.; Tieu, K.; Nedergaard, M. Neuronal adenosine release, and not astrocytic ATP release, mediates feedback inhibition of excitatory activity. Proc. Natl. Acad. Sci. U.S.A., 2012, 109(16), 6265-6270.

[70] Kochanek, P.M.; Vagni, V.A.; Janesko, K.L.; Washington, C.B.; Crumrine, P.K.; Garman, R.H.; Jenkins, L.W.; Clark, R.S.; Homanics, G.E.; Dixon, C.E.; Schnermann, J.; Jackson, E.K. Adenosine A1 receptor knockout mice develop lethal status epilepticus after experimental traumatic brain injury. J. Cereb. Blood Flow Metab., 2006, 26(4), 565-575.

[71] Ipata, P.L.; Tozzi, M.G. Recent advances in structure and function of cytosolic IMP-GMP specific 5'-nucleotidase II (cN-II). Purinergic Signal., 2006, 2(4), 669-675.

[72] Ipata, P.L.; Balestri, F.; Tozzi, M.G.; Camici, M. Brain nucleoside recycling. Metabolomics, 2012, DOI 10.1007/s11306-012-0457-x

[73] Brosh, S.; Sperling, O.; Dantziger, E.; Sidi, Y. Metabolism of guanine and guanine nucleotides in primary rat neuronal cultures. $J$. Neurochem., 1992, 58(4), 1485-1490.

[74] Brosh, S.; Zoref-Shani, E.; Danziger, E.; Bromberg, Y.; Sperling, O.; Sidi, Y. Adenine nucleotide metabolism in primary rat neuronal cultures. Int. J. Biochem. Cell Biol., 1996, 28(3), 319-328.

[75] Zimmermann, H. Biochemistry, localization and functional roles of ecto-nucleotidases in the nervous system. Prog. Neurobiol., 1996, 49(6), 589-618.

[76] Zimmermann, H. Extracellular purine metabolism. Drug. Develop. Res., 1996, 39(3-4), 337-352.

[77] Balestri, F.; Barsotti, C.; Lutzemberger, L.; Camici, M.; Ipata, P.L. Key role of uridine kinase and uridine phosphorylase in the homeo- 
static regulation of purine and pyrimidine salvage in brain. Neurochem. Int., 2007, 51(8), 517-523.

[78] Bourget, P.A.; Tremblay, G.C. Pyrimidine biosynthesis in rat brain. J. Neurochem., 1972, 19(7), 1617-1624.

[79] Allsop, J.; Watts, R.W. Purine synthesis and salvage in brain and liver. Adv. Exp. Med. Biol., 1984, 165(Pt B), 21-26.

[80] Linden, J.; Rosin, D.L. Purinergic systems. In: Basic Neurochemistry: Molecular, Cellular and Medical Aspects; Siegel, G.; Albers, R.W.; Brady, S.; Price, D., Eds.; Elsevier Academic Press Inc.: New York, 2006; 7th Edition, pp 303-316.

[81] Dunwiddie, T.V.; Masino, S.A. The role and regulation of adenosine in the central nervous system. Annu. Rev. Neurosci., 2001, 24, 31-55.

[82] Podgorska, M.; Kocbuch, K.; Pawelczyk, T. Recent advences in studies on biochemical and structural properties of equilibrative and concentrative nucleoside transporters. Acta Biochim. Pol., 2005, 52(4), 749-758.

[83] Kimura, T.; Ho, I.K.; Yamamoto, I. Uridine receptor: discovery and its involvement in sleep mechanism. Sleep, 2001, 24(3), 251260.

[84] Kovács, I.; Lasztóczi, B.; Szárics, É.; Héja, L.; Sági, G.; Kardos, J. Characterisation of an uridine-specific binding site in rat cerebrocortical homogenates. Neurochem. Int., 2003, 43(2), 101-112.

[85] Jacobson, K.A.; Gao, Z.G. Adenosine receptors as therapeutic targets. Nat. Rev. Drug. Discov., 2006, 5(3), 247-264.

[86] Boison, D. Modulators of nucleoside metabolism in the therapy of brain diseases. Curr. Top. Med. Chem., 2011, 11(8), 1068-1086.

[87] Kovacs, Z.; Dobolyi, A. Functions and metabolism of brain nucleosides and their metabolites. Curr. Top. Med. Chem., 2011, 11(8), 907-908.

[88] Corradetti, R.; Lo Conte, G.; Moroni, F.; Passani, M.B.; Pepeu, G. Adenosine decreases aspartate and glutamate release from rat hippocampal slices. Eur. J. Pharmacol., 1984, 104(1-2), 19-26.

[89] Frizzo, M.E.; Antunes Soares, F.A.; Dall'Onder, L.P.; Lara, D.R.; Swanson, R.A.; Souza, D.O. Extracellular conversion of guaninebased purines to guanosine specifically enhances astrocyte glutamate uptake. Brain Res., 2003, 972(1-2), 84-89.

[90] Guarneri, P.; Guarneri, R.; Mocciaro, C.; Piccoli, F. Interaction of uridine with GABA binding sites in cerebellar membranes of the rat. Neurochem. Res., 1983, 8(12), 1537-1545.

[91] Dragunow, M. Purinergic mechanisms in epilepsy. Prog. Neurobiol., 1988, 31(2), 85-108.

[92] Gouder, N.; Fritschy, J.M.; Boison, D. Seizure suppression by adenosine A1 receptor activation in a mouse model of pharmacoresistant epilepsy. Epilepsia, 2003, 44(7), 877-885.

[93] Gouder, N.; Scheurer, L.; Fritschy, J.M.; Boison. D. Overexpression of adenosine kinase in epileptic hippocampus contributes to epileptogenesis. J. Neurosci., 2004, 24(3), 692-701.

[94] Huber, A.; Güttinger, M.; Möhler, H.; Boison, D. Seizure suppression by adenosine $\mathrm{A}(2 \mathrm{~A})$ receptor activation in a rat model of audiogenic brainstem epilepsy. Neurosci. Lett., 2002, 329(3), 289292.

[95] De Sarro, G.; De Sarro, A.; Di Paola, E.D.; Bertorelli, R. Effects of adenosine receptor agonists and antagonists on audiogenic seizuresensible DBA/2 mice. Eur. J. Pharmacol., 1999, 371(2-3), 137145 .

[96] Hargus, N.J.; Jennings, C.; Perez-Reyes, E.; Bertram, E.H.; Patel, M.K. Enhanced actions of adenosine in medial entorhinal cortex layer II stellate neurons in temporal lobe epilepsy are mediated via A(1)-receptor activation. Epilepsia, 2012, 53(1), 168-176.

[97] Malva, J.O.; Silva, A.P.; Cunha, R.A. Presynaptic modulation controlling neuronal excitability and epileptogenesis: role of kainate, adenosine and neuropeptide Y receptors. Neurochem. Res., 2003, 28(10), 1501-1515.

[98] Sebastiao, A.M.; Ribeiro, J.A. Fine-tuning neuromodulation by adenosine. Trends Pharmacol. Sci., 2000, 21(9), 341-346.

[99] Fontanez, D.E.; Porter, J.T. Adenosine A1 receptors decrease thalamic excitation of inhibitory and excitatory neurons in the barrel cortex. Neuroscience, 2006, 137(4), 1177-1184.

[100] Haas, H.L.; Selbach, O. Functions of neuronal adenosine receptors. Naunyn Schmiedebergs Arch. Pharmacol., 2000, 362(4-5), 375381.

[101] Fredholm, B.B.; Ijzerman, A.P.; Jacobson, K.A.; Klotz, K.N.; Linden, J. International Union of Pharmacology. XXV. Nomenclature and classification of adenosine receptors. Pharmacol. Rev., 2001, 53(4), 527-552.
[102] Manzoni, O.J.; Manabe, T.; Nicoll, R.A. Release of adenosine by activation of NMDA receptors in the hippocampus. Science, 1994 265(5181), 2098-2101.

[103] Klaft, Z.J.; Schulz, S.B.; Maslarova, A.; Gabriel, S.; Heinemann, U.; Gerevich, Z. Extracellular ATP differentially affects epileptiform activity via purinergic $\mathrm{P} 2 \mathrm{X} 7$ and adenosine $\mathrm{A}(1)$ receptors in naive and chronic epileptic rats. Epilepsia, 2012, 53(11), 19781986.

[104] Dragunow, M.; Robertson, H.A. 8-Cyclopentyl 1,3-dimethylxanthine prolongs epileptic seizures in rats. Brain Res., 1987, 417(2), 377379.

[105] Handforth, A.; Treiman, D.M. Effect of an adenosine antagonist and an adenosine agonist on status entry and severity in a model of limbic status epilepticus. Epilepsy Res., 1994, 18(1), 29-42.

[106] Niglio, T.; Popoli, P.; Caporali, M.G.; Scotti de Carolis, A. Antiepileptic effects of N6-L-phenylisopropyladenosine (L-PIA) on penicillin-induced epileptogenic focus in rabbits. Pharmacol. Res. Commun., 1988, 20(7), 561-572.

[107] Dunwiddie, T.V. Endogenously released adenosine regulates excitability in the in vitro hippocampus. Epilepsia, 1980, 21(5), 541548.

[108] Avsar, E.; Empson, R.M. Adenosine acting via A1 receptors, controls the transition to status epilepticus-like behaviour in an in vitro model of epilepsy. Neuropharmacology, 2004, 47(3), 427-437.

[109] Schrader, J.; Wahl, M.; Kuschinsky, W.; Kreutzberg, G.W. Increase of adenosine content in cerebral cortex of the cat during bicuculline-induced seizure. Pflugers Arch., 1980, 387(3), 245-251.

[110] During, M.J.; Spencer, D.D. Adenosine: a potential mediator of seizure arrest and postictal refractoriness. Ann. Neurol., 1992, $32(5), 618-624$.

[111] Adén, U.; O'Connor, W.T.; Berman, R.F. Changes in purine levels and adenosine receptors in kindled seizures in the rat. Neuroreport, 2004, 15(10), 1585-1589.

[112] Slézia, A.; Kékesi, A.K.; Szikra, T.; Papp, A.M.; Nagy, K.; Szente, M.; Maglóczky, Zs.; Freund, T.F.; Juhász, G. Uridine release during aminopyridine-induced epilepsy. Neurobiol. Dis., 2004, 16(3), 490-499.

[113] Huber, A.; Padrun, V.; Déglon, N.; Aebischer, P.; Möhler, H.; Boison, D. Grafts of adenosine-releasing cells suppress seizures in kindling epilepsy. Proc. Natl. Acad. Sci. U.S.A., 2001, 98(13), 7611-7616.

[114] Boison, D.; Scheurer, L.; Tseng, J.L.; Aebischer, P.; Mohler, H. Seizure suppression in kindled rats by intraventricular grafting of an adenosine releasing synthetic polymer. Exp. Neurol., 1999, 160(1), 164-174.

[115] Bortolotto, Z.A.; Mello, L.E.; Turski, L.; Cavalheiro, E.A. Effects of 2-chloroadenosine on amygdaloid and hippocampal kindled seizures. Arch. Int. Pharmacodyn. Ther., 1985, 277(2), 313-320.

[116] Abdul-Ghani, A.S.; Attwell, P.J.; Bradford, H.F. The protective effect of 2-chloroadenosine against the development of amygdala kindling and on amygdala-kindled seizures. Eur. J. Pharmacol., 1997, 326(1), 7-14

[117] Anschel, D.J.; Ortega, E.L.; Kraus, A.C.; Fisher, R.S. Focally injected adenosine prevents seizures in the rat. Exp. Neurol., 2004, 190(2), 544-547

[118] Dunwiddie, T.V.; Worth, T. Sedative and anticonvulsant effects of adenosine analogs in mouse and rat. J. Pharmacol. Exp. Ther., 1982, 220(1), 70-76.

[119] Rosen, J.B.; Berman, R.F. Differential effects of adenosine analogs on amygdala, hippocampus, and caudate nucleus kindled seizures. Epilepsia, 1987, 28(6), 658-666.

[120] Yildirim, M.; Marangoz, C. Anticonvulsant effects of focal and intracerebroventricular adenosine on penicillin-induced epileptiform activity in rats. Brain Res., 2007, 1127(1), 193-200.

[121] Masino, S.A.; Geiger, J.D. Are purines mediators of the anticonvulsant/neuroprotective effects of ketogenic diets? Trends Neurosci., 2008, 31(6), 273-278.

[122] Braas, K.M.; Newby, A.C.; Wilson, V.S.; Snyder, S.H. Adenosinecontaining neurons in the brain localized by immunocytochemistry. J. Neurosci., 1986, 6(7), 1952-1961.

[123] Hagberg, H.; Andersson, P.; Lacarewicz, J.; Jacobson, I.; Butcher, S.; Sandberg, M. Extracellular adenosine, inosine, hypoxanthine, and xanthine in relation to tissue nucleotides and purines in rat striatum during transient ischemia. J. Neurochem., 1987, 49(1), $227-231$ 
[124] Dobolyi, Á.; Reichart, A.; Szikra, T.; Szilágyi, N.; Kékesi, A.K.; Karancsi, T.; Slegel, P.; Palkovits, M.; Juhász, G. Analysis of purine and pyrimidine bases, nucleosides and deoxynucleosides in brain microsamples (microdialysates and micropunches) and cerebrospinal fluid. Neurochem. Int., 1998, 32(3), 247-256.

[125] Ballarin, M.; Herrera-Marschitz, M.; Casas, M.; Ungerstedt, U. Striatal adenosine levels measured 'in vivo' by microdialysis in rats with unilateral dopamine denervation. Neurosci. Lett., 1987, 83(3), 338-344.

[126] Chen, Y.; Graham, D.I.; Stone, T.W. Release of endogenous adenosine and its metabolites by the activation of NMDA receptors in the rat hippocampus in vivo. Br. J. Pharmacol., 1992, 106(3), 632-638.

[127] Geiger, J.D.; Nagy, J.I. Distribution of adenosine deaminase activity in rat brain and spinal cord. J. Neurosci., 1986, 6(9), 2707-2714.

[128] Yamamoto, T.; Geiger, J.D.; Daddona, P.E.; Nagy, J.I. Subcellular, regional and immunhistochemical localisation of adenosine deaminase in various species. Brain Res. Bull., 1987, 19(4), 473484.

[129] Norstrand, I.F.; Siverls, V.C.; Libbin, R.M. Regional distribution of adenosine deaminase in the human neuraxis. Enzyme, 1984, 32(1), 20-25.

[130] Phillips, E.; Newsholme, E.A. Maximum activities, properties and distribution of 5'-nucleotidase, adenosine kinase and adenosine deaminase in rat and human brain. J. Neurochem., 1979, 33(2), 553-558.

[131] Geiger, J.D.; Nagy, J.I. Ontogenesis of adenosine deaminase activity in rat brain. $J$. Neurochem., 1987, 48(1), 147-153.

[132] Gharib, A.; Sarda, N.; Chabannes, B.; Cronenberger, L.; Pacheco, H. The regional concentrations of S-adenosyl-L-methionine, Sadenosyl-L-homocysteine and adenosine in rat brain. J. Neurochem., 1982, 38(3), 810-815.

[133] Trolin, C.G.; Lofberg, C.; Trolin, G.; Oreland, L. Brain ATP:Lmethionine S-adenosyltransferase (MAT), S-adenosylmethionine (SAM) and S-adenosylhomocysteine (SAH): regional distribution and age-related changes. Eur. Neuropsychopharmacol., 1994, 4(4), 469-477.

[134] Zhang, G.; Franklin, P.H.; Murray, T.F. Manipulation of endogenous adenosine in the rat prepiriform cortex modulates seizure susceptibility. J. Pharmacol. Exp. Ther., 1993, 264(3), 1415-1424.

[135] Etherington, L.A.; Patterson, G.E.; Meechan, L.; Boison, D.; Irving, A.J.; Dale, N.; Frenguelli, B.G. Astrocytic adenosine kinase regulates basal synaptic adenosine levels and seizure activity but not activity-dependent adenosine release in the hippocampus. $\mathrm{Neu}$ ropharmacology, 2009, 56(2), 429-437.

[136] Pak, M.A.; Haas, H.L.; Decking, U.K.; Schrader, J. Inhibition of adenosine kinase increases endogenous adenosine and depresses neuronal activity in hippocampal slices. Neuropharmacology, 1994, 33(9), 1049-1053.

[137] Lloyd, H.G.; Fredholm, B.B. Involvement of adenosine deaminase and adenosine kinase in regulating extracellular adenosine concentration in rat hippocampal slices. Neurochem. Int., 1995, 26(4), 387-395

[138] Van Dycke, A.; Raedt, R.; Dauwe, I.; Sante, T.; Wyckhuys, T.; Meurs, A.; Vonck, K.; Wadman, W.; Boon, P. Continuous local intrahippocampal delivery of adenosine reduces seizure frequency in rats with spontaneous seizures. Epilepsia, 2010, 51(9), 1721-1728.

[139] Ugarkar, B.G.; DaRe, J.M.; Kopcho, J.J.; Browne, C.E. $3^{\text {rd }}$.; Schanzer, J.M.; Wiesner, J.B.; Erion, M.D. Adenosine kinase inhibitors. 1. Synthesis, enzyme inhibition, and antiseizure activity of 5iodotubercidin analogues. J. Med. Chem., 2000, 43(15), 2883-2893.

[140] Ross, F.M.; Brodie, M.J.; Stone, T.W. Modulation by adenine nucleotides of epileptiform activity in the CA3 region of rat hippocampal slices. Br. J. Pharmacol., 1998, 123(1), 71-80.

[141] Wiesner, J.B.; Ugarkar, B.G.; Castellino, A.J.; Barankiewicz, J.; Dumas, D.P.; Gruber, H.E.; Foster, A.C.; Erion, M.D. Adenosine kinase inhibitors as a novel approach to anticonvulsant therapy. $J$. Pharmacol. Exp. Ther., 1999, 289(3), 1669-1677.

[142] Kowaluk, E.A.; Jarvis, M.F. Therapeutic potential of adenosine kinase inhibitors. Expert. Opin. Investig. Drugs, 2000, 9(3), 551564 .

[143] Murray, T.F.; Zhang, G.; Franklin, P.H. Manipulation of endogenous adenosine affects seizure susceptibility. Drug Dev. Res., 1993, 28(3), 410-415.
[144] Kovács, R.; Heinemann, U.; Steinhäuser, C. Mechanisms underlying blood-brain barrier dysfunction in brain pathology and epileptogenesis: Role of astroglia. Epilepsia, 2012, 53(Suppl 6), 53-59.

[145] Clasadonte, J.; Haydon, P.G. Astrocytes and Epilepsy. In: Jasper's Basic Mechanisms of the Epilepsies [Internet]; Noebels, J.L.; Avoli, M.; Rogawski. M.A.; Olsen, R.W; Delgado-Escueta, A.V., Eds.; Bethesda (MD): National Center for Biotechnology Information (US), 2012; 4th edition; Available from: Available from: http://www.ncbi.nlm.nih.gov/books/NBK98159/

[146] Studer, F.E.; Fedele, D.E.; Marowsky, A.; Schwerdel, C.; Wernli, K.; Vogt, K.; Fritschy, J.M.; Boison, D. Shift of adenosine kinase expression from neurons to astrocytes during postnatal development suggests dual functionality of the enzyme. Neuroscience, 2006, 142(1), 125-137.

[147] Haydon, P.G.; Carmignoto, G. Astrocyte control of synaptic transmission and neurovascular coupling. Physiol. Rev., 2006, 86(3), 1009-1031.

[148] Martín, E.D.; Fernández, M.; Perea, G.; Pascual, O.; Haydon, P.G.; Araque, A.; Ceña, V. Adenosine released by astrocytes contributes to hypoxia-induced modulation of synaptic transmission. Glia, 2007, 55(1), 36-45.

[149] Dunwiddie, T.V.; Diao, L.; Proctor, W.R. Adenine nucleotides undergo rapid, quantitative conversion to adenosine in the extracellular space in rat hippocampus. J. Neurosci., 1997, 17(20), 76737682.

[150] Boison, D. Engineered adenosine-releasing cells for epilepsy therapy: human mesenchymal stem cells and human embryonic stem cells. Neurotherapeutics, 2009, 6(2), 278-283.

[151] Boison, D. Adenosine dysfunction in epilepsy. Glia, 2012, 60(8), 1234-1243.

[152] Cunha, R.A. Neuroprotection by adenosine in the brain: from $A_{1}$ receptor activation to $\mathrm{A}_{2 \mathrm{~A}}$ receptor blockade. Purinergic Signal., 2005, 1(2), 111-134.

[153] Tian, G.F.; Azmi, H.; Takano, T.; Xu, Q.; Peng, W.; Lin, J.; Oberheim, N.; Lou, N.; Wang, X.; Zielke, H.R.; Kang, J.; Nedergaard, M. An astrocytic basis of epilepsy. Nat. Med., 2005, 11(9), 973981.

[154] Popoli, P.; Blum, D.; Martine, A.; Ledent, C.; Ceruti, S.; Abbracchio, M.P. Functions, dysfunctions and possible therapeutic relevance of adenosine $\mathrm{A}_{2 \mathrm{~A}}$ receptors in Huntington's disease. Prog. Neurobiol., 2007, 81(5-6), 331-348.

[155] Hindley, S.; Herman, M.A.; Rathbone, M.P. Stimulation of reactive astrogliosis in vivo by extracellular adenosine diphosphate or an adenosine A2 receptor agonist. J. Neurosci. Res., 1994, 38(4), 399406.

[156] Aronica, E.; Zurolo, E.; Iyer, A.; de Groot, M.; Anink, J.; Carbonell, C.; van Vliet, E.A.; Baayen, J.C.; Boison, D.; Gorter, J.A. Upregulation of adenosine kinase in astrocytes in experimental and human temporal lobe epilepsy. Epilepsia, 2011, 52(9), 1645-1655.

[157] Ciccarelli, R.; Di Iorio, P.; Ballerini, P.; Ambrosini, G.; Giuliani, P.; Tiboni, G.M.; Caciagli, F. Effects of exogenous ATP and related analogues on the proliferation rate of dissociated primary cultures of rat astrocytes. J. Neurosci. Res., 1994, 39(5), 556-566.

[158] Ekonomou, A.; Angelatou, F.; Vergnes, M.; Kostopoulos, G. Lower density of A1 adenosine receptors in nucleus reticularis thalami in rats with genetic absence epilepsy. Neuroreport, 1998, 9(9), 2135-2140.

[159] Ekonomou, A.; Sperk, G.; Kostopoulos, G.; Angelatou, F. Reduction of A1 adenosine receptors in rat hippocampus after kainic acid-induced limbic seizures. Neurosci. Lett., 2000, 284(1-2), 4952.

[160] Glass, M.; Faull, R.L.; Bullock, J.Y.; Jansen, K.; Mee, E.W.; Walker, E.B.; Synek, B.J.; Dragunow, M. Loss of A1 adenosine receptors in human temporal lobe epilepsy. Brain Res., 1996, 710(12), 56-68.

[161] Rebola, N.; Coelho, J.E.; Costenla, A.R.; Lopes, L.V.; Parada, A.; Oliveira, C.R.; Soares-da-Silva, P.; de Mendonça, A.; Cunha, R.A. Decrease of adenosine A1 receptor density and of adenosine neuromodulation in the hippocampus of kindled rats. Eur. J. Neurosci., 2003, 18(4), 820-828.

[162] Li, T.; Lytle, N.; Lan, J.Q.; Sandau, U.S.; Boison, D. Local disruption of glial adenosine homeostasis in mice associates with focal electrographic seizures: a first step in epileptogenesis? Glia, 2012, 60(1), 83-95.

[163] De Groot, M.; Iyer, A.; Zurolo, E.; Anink, J.; Heimans, J.J.; Boison, D.; Reijneveld, J.C.; Aronica, E. Overexpression of ADK in 
human astrocytic tumors and peritumoral tissue is related to tumorassociated epilepsy. Epilepsia, 2012, 53(1), 58-66.

[164] Boison, D. Adenosine Augmentation Therapy. In: Jasper's Basic Mechanisms of the Epilepsies [Internet]; Noebels, J.L.; Avoli, M.; Rogawski. M.A.; Olsen, R.W; Delgado-Escueta, A.V., Eds.; Bethesda (MD): National Center for Biotechnology Information (US), 2012; 4th edition; Available from: http://www.ncbi.nlm.nih.gov/ books/NBK98157/

[165] Li, T.; Ren, G.; Lusardi, T.; Wilz, A.; Lan, J.Q.; Iwasato, T.; Itohara, S.; Simon, R.P.; Boison, D. Adenosine kinase is a target for the prediction and prevention of epileptogenesis in mice. J. Clin. Invest., 2008, 118(2), 571-582.

[166] Aronica, E.; Sandau, U.S.; Iyer, A.; Boison, D. Glial adenosine kinase - A neuropathological marker of the epileptic brain. Neurochem. Int., 2013, Feb 4. pii: S0197-0186(13)00037-5. doi: 10.1016/j.neuint.2013.01.028. [Epub ahead of print]

[167] Lado, F.A.; Moshé, S.L. How do seizures stop? Epilepsia, 2008, 49(10), 1651-1664.

[168] Ault, B.; Wang, C.M. Adenosine inhibits epileptiform activity arising in hippocampal area CA3. Br. J. Pharmacol., 1986, 87(4), 695-703.

[169] Dunwiddie, T.V.; Hoffer, B.J. Adenine nucleotides and synaptic transmission in the in vitro rat hippocampus. Br. J. Pharmacol., 1980, 69(1), 59-68.

[170] Dupere, J.R.; Dale, T.J.; Starkey, S.J.; Xie, X. The anticonvulsant BW534U87 depresses epileptiform activity in rat hippocampal slices by an adenosinedependent mechanism and through inhibition of voltage-gated Na+ channels. Br. J. Pharmacol., 1999, 128(5), $1011-1020$.

[171] Southam, E.; Stratton, S.C.; Sargent, R.S.; Brackenborough, K.T.; Duffy, C.; Hagan, R.M.; Pratt, G.D.; Jones, S.A.; Morgan, P.F. Broad spectrum anticonvulsant activity of BW534U87: possible role of an adenosine-dependent mechanism. Pharmacol. Biochem. Behav., 2002, 74(1), 111-118.

[172] Liang, C.S.; Yang, F.W.; Chiang, K.T.; Ho, P.S. Allopurinol for treatment-resistant schizophrenia and epilepsy: a case report. Pharmacopsychiatry, 2010, 43(6), 233-234.

[173] Togha, M.; Akhondzadeh, S.; Motamedi, M.; Ahmadi, B.; Razeghi, S. Allopurinol as adjunctive therapy in intractable epilepsy: a double-blind and placebo-controlled trial. Arch. Med. Res., 2007, 38(3), 313-316.

[174] Zagnoni, P.G.; Bianchi, A.; Zolo, P.; Canger, R.; Cornaggia, C.; D'Alessandro, P.; DeMarco, P.; Pisani, F.; Gianelli, M.; Verzé, L. Allopurinol as add-on therapy in refractory epilepsy: a double-blind placebo-controlled randomized study. Epilepsia, 1994, 35(1), 107112.

[175] Coppola, G.; Pascotto, A. Double-blind, placebo-controlled, crossover trial of allopurinol as add-on therapy in childhood refractory epilepsy. Brain Dev., 1996, 18(1), 50-52.

[176] De Marco, P.; Zagnoni, P. Allopurinol in severe epilepsy. A preliminary report. Neuropsychobiology, 1988, 19(1), 51-53.

[177] Bruno, A.N.; Oses, J.P.; Bonan, C.D.; Walz, R.; Battastini, A.M.; Sarkis, J.J. Increase of nucleotidase activities in rat blood serum after a single convulsive injection of pentylenetetrazol. Neurosci. Res., 2002, 43(3), 283-288.

[178] Bruno, A.N.; Oses, J.P.; Amaral, O.; Coitinho, A.; Bonan, C.D.; Battastini, A.M.; Sarkis, J.J. Changes in nucleotide hydrolysis in rat blood serum induced by pentylenetetrazol-kindling. Brain Res. Mol. Brain Res., 2003, 114(2), 140-145.

[179] Bonan, C.D.; Walz, R.; Pereira, G.S.; Worm, P.V.; Battastini, A.M.; Cavalheiro, E.A.; Izquierdo, I.; Sarkis, J.J. Changes in synaptosomal ectonucleotidase activities in two rat models of temporal lobe epilepsy. Epilepsy Res., 2000, 39(3), 229-238.

[180] Vianna, E.P.; Ferreira, A.T.; Doná, F.; Cavalheiro, E.A.; da Silva Fernandes, M.J. Modulation of seizures and synaptic plasticity by adenosinergic receptors in an experimental model of temporal lobe epilepsy induced by pilocarpine in rats. Epilepsia, 2005, 46(Suppl. 5), 166-173.

[181] Oses, J.P.; Viola, G.G.; de Paula Cognato, G.; Júnior, V.H.; Hansel, G.; Böhmer, A.E.; Leke, R.; Bruno, A.N.; Bonan, C.D.; Bogo, M.R.; Portela, L.V.; Souza, D.O.; Sarkis, J.J. Pentylenetetrazol kindling alters adenine and guanine nucleotide catabolism in rat hippocampal slices and cerebrospinal fluid. Epilepsy Res., 2007, 75(2-3), 104-111.

[182] Lie, A.A.; Blümcke, I.; Beck, H.; Wiestler, O.D.; Elger, C.E.; Schoen, S.W. 5'-Nucleotidase activity indicates sites of synaptic plasticity and reactive synaptogenesis in the human brain. $J$. Neuropathol. Exp. Neurol., 1999, 58(5), 451-458.

[183] Vezzani, A.; Conti, M.; De Luigi, A.; Ravizza, T.; Moneta, D.; Marchesi, F.; De Simoni, M.G. Interleukin-1beta immunoreactivity and microglia are enhanced in the rat hippocampus by focal kainate application: functional evidence for enhancement of electrographic seizures. J. Neurosci., 1999, 19(12), 5054-5065.

[184] Vezzani, A.; Balosso, S.; Ravizza, T. The role of cytokines in the pathophysiology of epilepsy. Brain Behav. Immun., 2008, 22(6), 797-803.

[185] Vezzani, A.; Friedman, A.; Dingledine, R.J. The role of inflammation in epileptogenesis. Neuropharmacology, 2013, 69, 16-24.

[186] Li, G.; Bauer, S.; Nowak, M.; Norwood, B.; Tackenberg, B.; Rosenow, F.; Knake, S.; Oertel, W.H.; Hamer, H.M. Cytokines and epilepsy. Seizure, 2011, 20(3), 249-256.

[187] Fiebich, B.L.; Biber, K.; Gyufko, K.; Berger, M.; Bauer, J.; van Calker, D. Adenosine A2b receptors mediate an increase in interleukin (IL)-6 mRNA and IL-6 protein synthesis in human astroglioma cells. J. Neurochem., 1996, 66(4), 1426-1431.

[188] Fiebich, B.L.; Biber, K.; Lieb, K.; van Calker, D.; Berger, M.; Bauer, J.; Gebicke-Haerter, P.J. Cyclooxygenase-2 expression in rat microglia is induced by adenosine A2a-receptors. Glia, 1996, 18(2), 152-160.

[189] Hu, S.; Sheng, W.S.; Ehrlich, L.C.; Peterson, P.K.; Chao, C.C. Cytokine effects on glutamate uptake by human astrocytes. Neuroimmunomodulation, 2000, 7(3), 153-159.

[190] Rodgers, K.M.; Hutchinson, M.R.; Northcutt, A.; Maier, S.F.; Watkins, L.R.; Barth, D.S. The cortical innate immune response increases local neuronal excitability leading to seizures. Brain, 2009 , 132(Pt 9), 2478-2486.

[191] Akin, D.; Ravizza, T.; Maroso, M.; Carcak, N.; Eryigit, T.; Vanzulli, I.; Aker, R.G.; Vezzani, A.; Onat, F.Y. IL-1 $\beta$ is induced in reactive astrocytes in the somatosensory cortex of rats with genetic absence epilepsy at the onset of spike-and-wave discharges, and contributes to their occurrence. Neurobiol. Dis., 2011, 44(3), 259-269.

[192] Kovacs, Z.; Kékesi, K.A.; Szilágyi, N.; Abrahám, I.; Székács, D.; Király, N.; Papp, E.; Császár, I.; Szego, E.; Barabás, K.; Péterfy, H.; Erdei, A.; Bártfai, T.; Juhász, G. Facilitation of spike-wave discharge activity by lipopolysaccharides in Wistar Albino Glaxo/Rijswijk rats. Neuroscience, 2006, 140(2), 731-742.

[193] Kovacs, Z.; Czurkó, A.; Kékesi, K.A.; Juhász, G. Intracerebroventricularly administered lipopolysaccharide enhances spike-wave discharges in freely moving WAG/Rij rats. Brain Res. Bull., 2011, 85(6), 410-416.

[194] Sperlágh, B.; Baranyi, M.; Haskó, G.; Vizi, E.S. Potent effect of interleukin-1 beta to evoke ATP and adenosine release from rat hippocampal slices. J. Neuroimmunol., 2004, 151(1-2), 33-39.

[195] Cunha, R.A. Different cellular sources and different roles of adenosine: A1 receptor-mediated inhibition through astrocyticdriven volume transmission and synapse-restricted A2A receptormediated facilitation of plasticity. Neurochem. Int., 2008, 52(1-2), 65-72.

[196] Sebastião, A.M.; Ribeiro, J.A. Tuning and fine-tuning of synapses with adenosine. Curr. Neuropharmacol., 2009, 7(3), 180-194.

[197] Rebola, N.; Simões, A.P.; Canas, P.M.; Tomé, A.R.; Andrade, G.M.; Barry, C.E.; Agostinho, P.M.; Lynch, M.A.; Cunha, R.A. Adenosine A2A receptors control neuroinflammation and consequent hippocampal neuronal dysfunction. J. Neurochem., 2011, $117(1), 100-111$.

[198] Fotheringham, J.A.; Mayne, M.B.; Grant, J.A.; Geiger, J.D. Activation of adenosine receptors inhibits tumor necrosis factor-alpha release by decreasing TNF-alpha mRNA stability and p38 activity. Eur. J. Pharmacol., 2004, 497(1), 87-95.

[199] Van Calker, D.; Müller, M.; Hamprecht, B. Adenosine regulates via two different types of receptors, the accumulation of cyclic AMP in cultured brain cells. J. Neurochem., 1979, 33(5), 999-1005.

[200] Gebicke-Haerter, P.J.; Christoffel, F.; Timmer, J.; Northoff, H.; Berger, M.; Van Calker, D. Both adenosine A1- and A2-receptors are required to stimulate microglial proliferation. Neurochem. Int., 1996, 29(1), 37-42.

[201] Haskó, G.; Pacher, P.; Vizi, E.S.; Illes, P. Adenosine receptor signaling in the brain immune system. Trends Pharmacol. Sci., 2005 , 26(10), 511-516.

[202] Jarvis, M.F.; Yu, H.; Kohlhaas, K.; Alexander, K.; Lee, C.H.; Jiang, M.; Bhagwat, S.S.; Williams, M.; Kowaluk, E.A. ABT-702 (4amino-5-(3-bromophenyl)-7-(6-morpholinopyridin-3-yl)pyrido[2, 
3-d]pyrimidine), a novel orally effective adenosine kinase inhibitor with analgesic and anti-inflammatory properties: I. In vitro characterization and acute antinociceptive effects in the mouse. J. Pharmacol. Exp. Ther., 2000, 295(3), 1156-1164.

[203] Jarvis, M.F.; Yu, H.; McGaraughty, S.; Wismer, C.T.; Mikusa, J.; Zhu, C.; Chu, K.; Kohlhaas, K.; Cowart, M.; Lee, C.H.; Stewart, A.O.; Cox, B.F.; Polakowski, J.; Kowaluk, E.A. Analgesic and anti-inflammatory effects of A-286501, a novel orally active adenosine kinase inhibitor. Pain, 2002, 96(1-2), 107-118.

[204] Malhotra, J.; Gupta, Y.K. Effect of adenosine receptor modulation on pentylenetetrazole-induced seizures in rats. Br. J. Pharmacol., 1997, 120(2), 282-288.

[205] Monopoli, A.; Conti, A.; Dionisotti, S.; Casati, C.; Camaioni, E.; Cristalli, G.; Ongini, E. Pharmacology of the highly selective A1 adenosine receptor agonist 2-chloro-N6-cyclopentyladenosine. Arzneimittelforschung, 1994, 44(12), 1305-1312.

[206] McGaraughty, S.; Cowart, M.; Jarvis, M.F.; Berman, R.F. Anticonvulsant and antinociceptive actions of novel adenosine kinase inhibitors. Curr. Top. Med. Chem., 2005, 5(1), 43-58.

[207] Boison, D.; Scheurer, L.; Zumsteg, V.; Rülicke, T.; Litynski, P.; Fowler, B.; Brandner, S.; Mohler, H. Neonatal hepatic steatosis by disruption of the adenosine kinase gene. Proc. Natl. Acad. Sci. U.S.A., 2002, 99(10), 6985-6990.

[208] Jennings, L.L.; Hao, C.; Cabrita, M.A.; Vickers, M.F.; Baldwin, S.A.; Young, J.; Cass, C.E. Distinct regional distribution of human equilibrative nucleoside transporter proteins 1 and 2 (hENT1 and hENT2) in the central nervous system. Neuropharmacology, 2001, 40(5), 722-731.

[209] Baldwin, S.A.; Yao, S.Y.M.; Hyde, R.J.; Ng, A.M.L.; Foppolo, S.; Barnes, K.; Ritzel, M.W.L.; Cass, C.E.; Young, J.D. Functional characterization of novel human and mouse equilibrative nucleoside transporters (hENT3 and mENT3) located in intracellular membranes. J. Biol. Chem., 2005, 280(16), 15880-15887.

[210] Barnes, K.; Dobrzynski, H.; Foppolo, S.; Beal, P.R.; Ismat, F.; Scullion, E.R.; Sun, L.; Tellez, J.; Ritzel, M.W.; Claycomb, W.C.; Cass, C.E.; Young, J.D.; Billeter-Clark, R.; Boyett, M.R.; Baldwin, S.A. Distribution and functional characterization of equilibrative nucleoside transporter-4, a novel cardiac adenosine transporter activated at acidic pH. Circ. Res., 2006, $99(5), 510-519$.

[211] Pennycooke, M.; Chaudary, N.; Shuralyova, I.; Zhang, Y.; Coe, I.R. Differential expression of human nucleoside transporters in normal and tumor tissue. Biochem. Biophys. Res. Commun., 2001, 280(3), 951-959.

[212] Ritzel, M.W.L.; Ng, A.M.L.; Yao, S.Y.M.; Graham, K.; Loewen, S.K.; Smith, K.M.; Ritzel, R.G.; Mowles, D.A.; Carpenter, P.; Chen, X.Z.; Karpinski, E.; Hyde, R.J.; Baldwin, S.A.; Cass, C.E.; Young, J.D. Molecular identification and characterization of novel human and mouse concentrative $\mathrm{Na}^{+}$-nucleoside cotransporter proteins (hCNT3 and mCNT3) broadly selective for purine and pyrimidine nucleosides (system cib). J. Biol. Chem., 2001, 276(4), 2914-2927.

[213] Dragunow, M.; Goddard, G.V. Adenosine modulation of amygdala kindling. Exp. Neurol., 1984, 84(3), 654-665.

[214] Zhang, G.; Franklin, P.H.; Murray, T.F. Anticonvulsant effect of N-ethylcarboxamidoadenosine against kainic acid-induced behavioral seizures in the rat prepiriform cortex. Neurosci. Lett., 1990, 114(3), 345-350.

[215] Akula, K.K.; Dhir, A.; Kulkarni, S.K. Rofecoxib, a selective cyclooxygenase-2 (COX-2) inhibitor increases pentylenetetrazol seizure threshold in mice: possible involvement of adenosinergic mechanism. Epilepsy Res., 2008, 78(1), 60-70.

[216] George, B.; Kulkarni, S.K. Modulation of lithium-pilocarpineinduced status epilepticus by adenosinergic agents. Methods Find. Exp. Clin. Pharmacol., 1997, 19(5), 329-333.

[217] Karatas, A.; Gokce, F.; Demir, S.; Ankarali, S. The effect of intraarterial papaverine on ECoG activity in the ketamine anesthetized rat. Neurosci. Lett., 2008, 445(1), 58-61.

[218] Ashton, D.; De Prins, E.; Willems, R.; Van Belle, H.; Wauquier, A. Anticonvulsant action of the nucleoside transport inhibitor, soluflazine, on synaptic and non-synaptic epileptogenesis in the guineapig hippocampus. Epilepsy Res., 1988, 2(2), 65-71.

[219] Kostopoulos, G.; Drapeau, C.; Avoli, M.; Olivier, A.; Villemeure, J.G. Endogenous adenosine can reduce epileptiform activity in the human epileptogenic cortex maintained in vitro. Neurosci. Lett., 1989, 106(1-2), 119-124.
[220] Narimatsu, E.; Aoki, M. Involvement of the adenosine neuromodulatory system in the benzodiazepine-induced depression of excitatory synaptic transmissions in rat hippocampal neurons in vitro. Neurosci. Res., 1999, 33(1), 57-64.

[221] Van Belle, H. Nucleoside transport inhibition: a therapeutic approach to cardioprotection via adenosine? Cardiovasc. Res., 1993, 27(1), 68-76.

[222] Noji, T.; Karasawa, A.; Kusaka, H. Adenosine uptake inhibitors. Eur. J. Pharmacol., 2004, 495(1), 1-16.

[223] Carhuapoma, J.R.; Qureshi, A.I.; Tamargo, R.J.; Mathis, J.M.; Hanley, D.F. Intra-arterial papaverine-induced seizures: case report and review of the literature. Surg. Neurol., 2001, 56(3), 159-163.

[224] Ramzan, I. Proconvulsant effect of papaverine on theophyllineinduced seizures in rats. Clin. Exp. Pharmacol. Physiol., 1989, 16(5), 425-427.

[225] Czuczwar, S.J.; Janusz, W.; Wamil, A.; Kleinrok, Z. Inhibition of aminophylline-induced convulsions in mice by antiepileptic drugs and other agents. Eur. J. Pharmacol., 1987, 144(3), 309-315.

[226] Weber, R.G.; Jones, C.R.; Palacios, J.M.; Lohse, M.J. Autoradiographic visualization of A1-adenosine receptors in brain and peripheral tissues of rat and guinea pig using 125I-HPIA. Neurosci. Lett., 1988, 87(3), 215-220.

[227] Svenningsson, P.; Hall, H.; Sedvall, G.; Fredholm, B.B. Distribution of adenosine receptors in the post mortem human brain: an extended autoradiographic study. Synapse, 1997, 27(4), 322-335.

[228] Jahanshahi, A.; Mirnajafi-Zadeh, J.; Javan, M.; Mohammad-Zadeh, M.; Rohani, R. The antiepileptogenic effect of electrical stimulation at different low frequencies is accompanied with change in adenosine receptors gene expression in rats. Epilepsia, 2009, 50(7), 1768-1779.

[229] Biber, K.; Lubrich, B.; Fiebich, B.L.; Boddeke, H.W.; van Calker, D. Interleukin-6 enhances expression of adenosine A(1) receptor mRNA and signaling in cultured rat cortical astrocytes and brain slices. Neuropsychopharmacology, 2001, 24(1), 86-96.

[230] Biber, K.; Pinto-Duarte, A.; Wittendorp, M.C.; Dolga, A.M.; Fernandes, C.C.; Von Frijtag Drabbe Künzel, J.; Keijser, J.N.; de Vries, R.; Ijzerman, A.P.; Ribeiro, J.A.; Eisel, U.; Sebastião, A.M.; Boddeke, H.W. Interleukin-6 upregulates neuronal adenosine A1 receptors: implications for neuromodulation and neuroprotection. Neuropsychopharmacology, 2008, 33(9), 2237-2250.

[231] Lehtimäki, K.A.; Peltola, J.; Koskikallio, E.; Keränen, T.; Honkaniemi, J. Expression of cytokines and cytokine receptors in the rat brain after kainic acid-induced seizures. Brain Res. Mol. Brain Res., 2003, 110(2), 253-260.

[232] Lachos, J.; Zattoni, M.; Wieser, H.G.; Fritschy, J.M.; Langmann, T.; Schmitz, G.; Errede, M.; Virgintino, D.; Yonekawa, Y.; Frei, K. Characterization of the gene expression profile of human hippocampus in mesial temporal lobe epilepsy with hippocampal sclerosis. Epilepsy Res. Treat., 2011, 2011 (758407), 1-11.

[233] Yu, N.; Di, Q.; Hu, Y.; Zhang, Y.F.; Su, L.Y.; Liu, X.H.; Li, L.C. A meta-analysis of pro-inflammatory cytokines in the plasma of epileptic patients with recent seizure. Neurosci. Lett., 2012, 514(1), 110-115.

[234] Daval, J.L.; Sarfati, A. Effects of bicuculline-induced seizures on benzodiazepine and adenosine receptors in developing rat brain. Life Sci., 1987, 41(14), 1685-1693.

[235] Cano-Martínez, A.; Villalobos-Molina, R.; Rocha, L. Effects of chronic morphine and $\mathrm{N}(6)$-cyclopentyl-adenosine administration on kainic acid-induced status epilepticus. Epilepsy Res., 2001, 44(2-3), 89-96.

[236] Angelatou, F.; Pagonopoulou, O.; Maraziotis, T.; Olivier, A.; Villemeure, J.G.; Avoli, M.; Kostopoulos, G. Upregulation of A1 adenosine receptors in human temporal lobe epilepsy: a quantitative autoradiographic study. Neurosci. Lett., 1993, 163(1), 11-14.

[237] Tchekalarova, J.; Sotiriou, E.; Georgiev, V.; Kostopoulos, G.; Angelatou, F. Up-regulation of adenosine A1 receptor binding in pentylenetetrazol kindling in mice: effects of angiotensin IV. Brain Res., 2005, 1032(1-2), 94-103.

[238] Pagonopoulou, O.; Efthimiadou, A.; Asimakopoulos, B.; Nikolettos, N.K. Modulatory role of adenosine and its receptors in epilepsy: possible therapeutic approaches. Neurosci. Res., 2006, 56(1), 14-20.

[239] Ohta, Y.; Nariai, T.; Kurumaji, A.; Hirakawa, K.; Ohno, K. Increased binding of inhibitory neuronal receptors in the hippocampus in kainate-treated rats with spontaneous limbic seizures. $J$. Clin. Neurosci., 2010, 17(5), 612-616. 
[240] Castillo, C.A.; Albasanz, J.L.; León, D.; Jordán, J.; Pallás, M.; Camins, A.; Martín, M. Age-related expression of adenosine receptors in brain from the senescense-accerelated mouse. Exp. Gerontol., 2009, 44(6-7), 453-461.

[241] Sperlágh, B.; Zsilla, G.; Baranyi, M.; Kékes-Szabó, A.; Vizi, E.S. Age-dependent changes of presynaptic neuromodulation via $\mathrm{A}_{1}$ adenosine receptors in rat hippocampal slices. Int. J. Dev. Neurosci., 1997, 15(6), 739-747.

[242] Cunha, R.A.; Constantino, M.C.; Sebastião, A.M.; Ribeiro, J.A. Modification of $\mathrm{A}_{1}$ and $\mathrm{A}_{2 \mathrm{a}}$ adenosine receptor binding in aged striatum, hippocampus and cortex of the rat. Neuroreport, 1995, 6(11), 1583-1588.

[243] Deckert, J.; Abel, F.; Kunig, G.; Hartmann, J.; Senitz, D.; Maier, H.; Ransmayr, G.; Riederer, P. Loss of human hippocampal adenosine $A_{1}$ receptors in dementia: evidence for lack of specificity. Neurosci. Lett., 1998, 244(1), 1-4.

[244] Ekonomou, A.; Pagonopoulou, O.; Angelatou, F. Age-dependent changes in adenosine $A_{1}$ receptor and uptake site binding in the mouse brain: an autoradiographic study. J. Neurosci. Res., 2000, $60(2), 257-265$.

[245] Meyer, P.T.; Elmenhorst, D.; Boy, C.; Winz, O.; Matusch, A.; Zilles, K.; Bauer, A. Effect of aging on cerebral $\mathrm{A}_{1}$ adenosine receptors: a [18F]CPFPX PET study in humans. Neurobiol. Aging, 2007, 28(12), 1914-1924.

[246] Xu, K.; Bastia, E.; Schwarzschild, M. Therapeutic potential of adenosine $\mathrm{A}_{2 \mathrm{~A}}$ receptor antagonists in Parkinson's disease. Pharmacol. Ther., 2005, 105(3), 267-310.

[247] Johansson, B.; Georgiev, V.; Fredholm, B.B. Distribution and postnatal ontogeny of adenosine $\mathrm{A}_{2 \mathrm{~A}}$ receptors in rat brain: comparison with dopamine receptors. Neuroscience, 1997, 80(4), 1187 1207.

[248] Lopes, L.V.; Cunha, R.A.; Ribeiro, J.A. Increase in the number, G protein coupling, and efficiency of facilitatory adenosine $\mathrm{A}_{2 \mathrm{~A}}$ receptors in the limbic cortex, but not striatum, of aged rats. $J$. Neurochem., 1999, 73(4), 1733-1738.

[249] Wardas, J. Neuroprotective role of adenosine in the CNS. Pol. J. Pharmacol., 2002, 54(4), 313-326.

[250] Ribeiro, J.A.; Sebastião, A.M. Modulation and metamodulation of synapses by adenosine. Acta Physiol. (Oxf.), 2010, 199(2), 161169.

[251] Ribeiro, J.A.; Sebastiao, A.M.; de Mendonca, A. Adenosine receptors in the nervous system: pathophysiological implications. Prog. Neurobiol., 2002, 68(6), 377-392.

[252] Cunha, R.A. Adenosine as a neuromodulator and as a homeostatic regulator in the nervous system: different roles, different sources and different receptors. Neurochem. Int., 2001, 38(2), 107-125.

[253] Khan, G.M.; Smolders, I.; Ebinger, G.; Michotte, Y. 2-chloro-N(6)cyclopentyladenosineelicited attenuation of evoked glutamate release is not sufficient to give complete protection against pilocarpine-induced seizures in rats. Neuropharmacology, 2001, 40(5), 657-667.

[254] Concas, A.; Santoro, G.; Mascia, M.P.; Maciocco, E.; Dazzi, L.; Ongini, E.; Biggio, G. Anticonvulsant doses of 2-chloro-N6cyclopentyladenosine, an adenosine A1 receptor agonist, reduce GABAergic transmission in different areas of the mouse brain. $J$. Pharmacol. Exp. Ther., 1993, 267(2), 844-851.

[255] Mareš, P. Anticonvulsant action of 2-chloroadenosine against pentetrazol-induced seizures in immature rats is due to activation of A1 adenosine receptors. J. Neural. Transm., 2010, 117(11), 12691277.

[256] Adami, M.; Bertorelli, R.; Ferri, N.; Foddi, M.C. Ongini E. Effects of repeated administration of selective adenosine $\mathrm{A} 1$ and $\mathrm{A} 2 \mathrm{~A}$ receptor agonists on pentylenetetrazole-induced convulsions in the rat. Eur. J. Pharmacol., 1995, 294(2-3), 383-389.

[257] Young, D.; Dragunow, M. Status epilepticus may be caused by loss of adenosine anticonvulsant mechanisms. Neuroscience, 1994, 58(2), 245-261.

[258] Cavalheiro, E.A.; Calderazzo Filho, L.S.; Bortolotto, Z.A.; Mello, L.; Turski, L. Anticonvulsant role of adenosine. Pol. J. Pharmacol. Pharm., 1987, 39(5), 537-543.

[259] Pourgholami, M.H.; Rostampour, M.; Mirnajafi-Zadeh, J.; Palizvan, M.R. Intra-amygdala infusion of 2-chloroadenosine suppresses amygdala-kindled seizures. Brain Res., 1997, 775(1-2), 37-42.

[260] Mirnajafi-Zadeh, J.; Pourgholami, M.H.; Palizvan, M.R.; Rostampour, M.; Fallahi, M. Anticonvulsant action of 2-chloroadenosine injected focally into the perirhinal cortex in amygdaloid kindled rats. Epilepsy Res., 1999, 37(1), 37-43.

[261] Turski, W.A.; Cavalheiro, E.A.; Ikonomidou, C.; Mello, L.E.; Bortolotto, Z.A.; Turski, L. Effects of aminophylline and 2chloroadenosine on seizures produced by pilocarpine in rats: morphological and electroencephalographic correlates. Brain Res., 1985, 361(1-2), 309-323.

[262] Khan, G.M.; Smolders, I.; Ebinger, G.; Michotte, Y. Anticonvulsant effect and neurotransmitter modulation of focal and systemic 2-chloroadenosine against the development of pilocarpine-induced seizures. Neuropharmacology, 2000, 39(12), 2418-2432.

[263] De Sarro, G.; De Sarro, A.; Meldrum, B.S. Anticonvulsant action of 2-chloroadenosine injected focally into the inferior colliculus and substantia nigra. Eur. J. Pharmacol., 1991, 194(2-3), 145-152.

[264] O'Shaughnessy, C.T.; Aram, J.A.; Lodge, D. A1 adenosine receptor-mediated block of epileptiform activity induced in zero magnesium in rat neocortex in vitro. Epilepsy Res., 1988, 2(5), 294-301.

[265] Murray, T.F.; Sylvester, D.; Schultz, C.S.; Szot, P. Purinergic modulation of the seizure threshold for pentylenetetrazol in the rat. Neuropharmacology, 1985, 24(8), 761-766.

[266] Zuchora, B.; Wielosz, M.; Urbańska, E.M. Adenosine A1 receptors and the anticonvulsant potential of drugs effective in the model of 3-nitropropionic acid-induced seizures in mice. Eur. Neuropsychopharmacol., 2005, 15(1), 85-93.

[267] Franklin, P.H.; Zhang, G.; Tripp, E.D.; Murray, T.F. Adenosine A1 receptor activation mediates suppression of (-) bicuculline methiodide-induced seizures in rat prepiriform cortex. J. Pharmacol. Exp. Ther., 1989, 251(3), 1229-1236.

[268] Rosim, F.E.; Persike, D.S.; Nehlig, A.; Amorim, R.P.; de Oliveira, D.M.; Fernandes, M.J. Differential neuroprotection by A(1) receptor activation and $\mathrm{A}(2 \mathrm{~A})$ receptor inhibition following pilocarpineinduced status epilepticus. Epilepsy Behav., 2011, 22(2), 207-213.

[269] Longo, R.; Zeng, Y.C.; Sagratella, S. Opposite modulation of 4aminopyridine and hypoxic hyperexcitability by A1 and A2 adenosine receptor ligands in rat hippocampal slices. Neurosci. Lett., 1995, 200(1), 21-24.

[270] Ormandy, G.C.; Jope, R.S. Pertussis toxin potentiates seizures induced by pilocarpine, kainic acid and N-methyl-D-aspartate. Brain Res., 1991, 553(1), 51-57.

[271] Girardi, E.S.; Canitrot, J.; Antonelli, M.; González, N.N.; Coirini, H. Differential expression of cerebellar metabotropic glutamate receptors mGLUR2/3 and mGLUR4a after the administration of a convulsant drug and the adenosine analogue cyclopentyladenosine. Neurochem. Res., 2007, 32(7), 1120-1128.

[272] Barraco, R.A.; Swanson, T.H.; Phillis, J.W.; Berman, R.F. Anticonvulsant effects of adenosine analogues on amygdaloid-kindled seizures in rats. Neurosci. Lett., 1984, 46(3), 317-322.

[273] Hosseinmardi, N.; Mirnajafi-Zadeh, J.; Fathollahi, Y.; Shahabi, P. The role of adenosine $\mathrm{A} 1$ and $\mathrm{A} 2 \mathrm{~A}$ receptors of entorhinal cortex on piriform cortex kindled seizures in rats. Pharmacol. Res., 2007, 56(2), 110-117.

[274] Alasvand Zarasvand, M.; Mirnajafi-Zadeh, J.; Fathollahi, Y.; Palizvan, M.R. Anticonvulsant effect of bilateral injection of N6cyclohexyladenosine into the CA1 region of the hippocampus in amygdala-kindled rats. Epilepsy Res., 2001, 47(1-2), 141-149.

[275] Mirnajafi-Zadeh, J.; Fathollahi, Y.; Pourgholami, M.H. Intraperitoneal and intraamygdala N(6)-cyclohexyladenosine suppress hippocampal kindled seizures in rats. Brain Res., 2000, 858(1), 48-54.

[276] Zeraati, M.; Mirnajafi-Zadeh, J.; Fathollahi, Y.; Namvar, S.; Rezvani, M.E. Adenosine A1 and A2A receptors of hippocampal CA1 region have opposite effects on piriform cortex kindled seizures in rats. Seizure, 2006, 15(1), 41-48.

[277] Namvar, S.; Mirnajafi-Zadeh, J.; Fathollahi, Y.; Zeraati, M. The role of piriform cortex adenosine A1 receptors on hippocampal kindling. Can. J. Neurol. Sci., 2008, 35(2), 226-231.

[278] Zgodziński, W.; Rubaj, A.; Kleinrok, Z.; Sieklucka-Dziuba, M. Effect of adenosine A1 and A2 receptor stimulation on hypoxiainduced convulsions in adult mice. Pol. J. Pharmacol., 2001, 53(1), 83-92.

[279] Jaishree, J.; Kumaresan, S.; Sudha, S.; David, J.; Kulkarni, C. Individual and combined effects of N6-cyclopentyladenosine, flunarizine and diazepam on aminophylline-induced recurrent generalized seizures in mice. Pol. J. Pharmacol., 2003, 55(4), 559-564.

[280] Sagratella, S.; Frank, C.; Benedetti, M.; Scotti de Carolis, A. Modulatory action of purinergic drugs on high potassium-induced 
epileptiform bursting in rat hippocampal slices. Pharmacol. Res. Commun., 1987, 19(11), 819-826.

[281] Rezvani, M.E.; Roohbakhsh, A.; Allahtavakoli, M.; Shamsizadeh, A. Anticonvulsant effect of aqueous extract of Valeriana officinalis in amygdala-kindled rats: possible involvement of adenosine. $J$. Ethnopharmacol., 2010, 127(2), 313-318.

[282] Li, T.; Quan Lan, J.; Fredholm, B.B.; Simon, R.P.; Boison, D. Adenosine dysfunction in astrogliosis: cause for seizure generation? Neuron Glia Biol., 2007, 3(4), 353-366.

[283] Fedele, D.E.; Li, T.; Lan, J.Q.; Fredholm, B.B.; Boison, D. Adenosine A1 receptors are crucial in keeping an epileptic focus localized. Exp. Neurol., 2006, 200(1), 184-190.

[284] Ilie, A.; Raimondo, J.V.; Akerman, C.J. Adenosine release during seizures attenuates GABAA receptor-mediated depolarization. $J$. Neurosci., 2012, 32(15), 5321-5332.

[285] Łuszczki, J.J.; Kozicka, M.; Swiader, M.J.; Czuczwar, S.J. 2Chloro-N6-cyclopentyladenosine enhances the anticonvulsant action of carbamazepine in the mouse maximal electroshock-induced seizure model. Pharmacol. Rep., 2005, 57(6), 787-794.

[286] Groomes, L.B.; Pyzik, P.L.; Turner, Z.; Dorward, J.L.; Goode, V.H.; Kossoff, E.H. Do patients with absence epilepsy respond to ketogenic diets? J. Child. Neurol., 2011, 26(2), 160-165.

[287] Kossoff, E.H. The ketogenic diet: an appropriate first-line therapy? Expert Rev. Neurother., 2010, 10(6), 843-845.

[288] Kossoff, E.H.; Rho, J.M. Ketogenic diets: evidence for short- and long-term efficacy. Neurotherapeutics, 2009, 6(2), 406-414.

[289] Kawamura, M. Jr.; Ruskin, D.N.; Masino, S.A. Metabolic autocrine regulation of neurons involves cooperation among pannexin hemichannels, adenosine receptors, and KATP channels. J. Neurosci., 2010, 30(11), 3886-3895.

[290] Masino, S.A.; Li, T.; Theofilas, P.; Sandau, U.S.; Ruskin, D.N.; Fredholm, B.B.; Geiger, J.D.; Aronica, E.; Boison, D. A ketogenic diet suppresses seizures in mice through adenosine $\mathrm{A}_{1}$ receptors. $J$. Clin. Invest., 2011, 121(7), 2679-2683.

[291] Masino, S.A.; Rho, J.M. Mechanisms of Ketogenic Diet Action. In: Jasper's Basic Mechanisms of the Epilepsies [Internet]; Noebels, J.L.; Avoli, M.; Rogawski. M.A.; Olsen, R.W; Delgado-Escueta, A.V., Eds.; Bethesda (MD): National Center for Biotechnology Information (US), 2012; 4th edition; Available from: http://www.ncbi.nlm.nih.gov/books/NBK98219/

[292] Masino, S.A.; Kawamura, M. Jr.; Ruskin, D.N.; Geiger, J.D.; Boison, D. Purines and neuronal excitability: links to the ketogenic diet. Epilepsy Res., 2012, 100(3), 229-238.

[293] Segal, M. Intracellular analysis of a postsynaptic action of adenosine in the rat hippocampus. Eur. J. Pharmacol., 1982, 79(3-4), 193-199.

[294] Dunwiddie, T.V. Interactions between the effects of adenosine and calcium on synaptic responses in rat hippocampus in vitro. $J$. Physiol., 1984, 350, 545-559.

[295] Haas, H.L.; Greene, R.W. Adenosine enhances afterhyperpolarization and accommodation in hippocampal pyramidal cells. Pflugers Arch., 1984, 402(3), 244-247.

[296] Borowicz, K.K.; Kleinrok, Z.; Czuczwar, S.J. N(6)-2-(4aminophenyl)ethyl-adenosine enhances the anticonvulsive action of conventional antiepileptic drugs in the kindling model of epilepsy in rats. Eur. Neuropsychopharmacol., 2000, 10(4), 237-243.

[297] Dragunow, M.; Goddard, G.V.; Laverty, R. Is adenosine an endogenous anticonvulsant? Epilepsia, 1985, 26(5), 480-487.

[298] Gomes, C.V.; Kaster, M.P.; Tomé, A.R.; Agostinho, P.M.; Cunha, R.A. Adenosine receptors and brain diseases: neuroprotection and neurodegeneration. Biochim. Biophys. Acta., 2011, 1808(5), 13801399.

[299] Moreau, J.L.; Huber, G. Central adenosine $A_{2 \mathrm{~A}}$ receptors: an overview. Brain Res. Rev., 1999, 31(1), 65-82.

[300] Etherington, L.A.; Frenguelli, B.G. Endogenous adenosine modulates epileptiform activity in rat hippocampus in a receptor subtypedependent manner. Eur. J. Neurosci., 2004, 19(9), 2539-2550.

[301] Li, X.; Kang, H.; Liu, X.; Liu, Z.; Shu, K.; Chen, X.; Zhu, S. Effect of adenosine A2A receptor antagonist ZM241385 on amygdalakindled seizures and progression of amygdala kindling. J. Huazhong. Univ. Sci. Technolog. Med. Sci., 2012, 32(2), 257-264.

[302] D'Alimonte, I.; D'Auro, M.; Citraro, R.; Biagioni, F.; Jiang, S.; Nargi, E.; Buccella, S.; Di Iorio, P.; Giuliani, P.; Ballerini, P.; Caciagli, F.; Russo, E.; De Sarro, G.; Ciccarelli, R. Altered distribution and function of $\mathrm{A} 2 \mathrm{~A}$ adenosine receptors in the brain of
WAG/Rij rats with genetic absence epilepsy, before and after appearance of the disease. Eur. J. Neurosci., 2009, 30(6), 1023-1035.

[303] Moschovos, C.; Kostopoulos, G.; Papatheodoropoulos, C. Endogenous adenosine induces NMDA receptor-independent persistent epileptiform discharges in dorsal and ventral hippocampus via activation of A2 receptors. Epilepsy Res., 2012, 100(1-2), 157-167.

[304] El Yacoubi, M.; Ledent, C.; Parmentier, M.; Costentin, J.; Vaugeois, J.M. Evidence for the involvement of the adenosine $\mathrm{A}(2 \mathrm{~A})$ receptor in the lowered susceptibility to pentylenetetrazolinduced seizures produced in mice by long-term treatment with caffeine. Neuropharmacology, 2008, 55(1), 35-40.

[305] El Yacoubi, M.; Ledent, C.; Parmentier, M.; Costentin, J.; Vaugeois, J.M. Adenosine A2A receptor deficient mice are partially resistant to limbic seizures. Naunyn Schmiedebergs Arch. Pharmacol., 2009, 380(3), 223-232.

[306] Fukuda, M.; Suzuki, Y.; Hino, H.; Ishii, E. Over-activation of adenosine $\mathrm{A}(2 \mathrm{~A})$ receptors and sudden unexpected death in epilepsy. Epilepsy Behav., 2012, 23(3), 387-388.

[307] Shen, H.Y.; Li, T.; Boison, D. A novel mouse model for sudden unexpected death in epilepsy (SUDEP): role of impaired adenosine clearance. Epilepsia, 2010, $51(3), 465-468$.

[308] Rebola, N.; Porciúncula, L.O.; Lopes, L.V.; Oliveira, C.R.; Soaresda-Silva, P.; Cunha, R.A. Long-term effect of convulsive behavior on the density of adenosine $\mathrm{A} 1$ and $\mathrm{A} 2 \mathrm{~A}$ receptors in the rat cerebral cortex. Epilepsia, 2005, 46(Suppl 5), 159-165.

[309] Ilbay, G.; Sahin, D.; Karson, A.; Ates, N. Effects of adenosine administration on spike-wave discharge frequency in genetically epileptic rats. Clin. Exp. Pharmacol. Physiol., 2001, 28(8), 643646.

[310] Laudadio, M.A.; Psarropoulou, C. The A3 adenosine receptor agonist 2-Cl-IB-MECA facilitates epileptiform discharges in the CA3 area of immature rat hippocampal slices. Epilepsy Res., 2004, 59(2-3), 83-94.

[311] Rebola, N.; Rodrigues, R.J.; Oliveira, C.R.; Cunha, R.A. Different roles of adenosine $\mathrm{A} 1, \mathrm{~A} 2 \mathrm{~A}$ and $\mathrm{A} 3$ receptors in controlling kainate-induced toxicity in cortical cultured neurons. Neurochem. Int., 2005, 47(5), 317-325.

[312] Daval, J.L.; Werck, M.C.; Nehlig, A.; Pereira de Vasconcelos, A. Quantitative autoradiographic study of the postnatal development of adenosine A1 receptors and their coupling to G proteins in the rat brain. Neuroscience, 1991, 40(3), 841-851.

[313] Psarropoulou, C.; Kostopoulos, G.; Haas, H.L. An electrophysiological study of the ontogenesis of adenosine receptors in the CA1 area of rat hippocampus. Brain Res. Dev. Brain Res., 1990, 55(1), 147-150.

[314] Kovacs, Z.; Czurko, A.; Kekesi, K.A.; Juhasz, G. The effect of intraperitoneally administered dimethyl sulfoxide on absence-like epileptic activity of freely moving WAG/Rij rats. J. Neurosci. Methods, 2011, 197(1), 133-136.

[315] Palkovits, M.; Harvey-White, J.; Liu, J.; Kovacs, ZS.; Bobest, M.; Lovas, G.; Bago, A.G.; Kunos, G. Regional distribution and effects of postmortal delay on endocannabinoid content of the human brain. Neuroscience, 2008, 152(4), 1032-1039.

[316] Shryock, J.C.; Belardinelli, L. Adenosine and adenosine receptors in the cardiovascular system: biochemistry, physiology, and pharmacology. Am. J. Cardiol., 1997, 79(12A), 2-10.

[317] Brodie, M.S.; Lee, K.; Fredholm, B.B.; Ståhle, L.; Dunwiddie, T.V. Central versus peripheral mediation of responses to adenosine receptor agonists: evidence against a central mode of action. Brain Res., 1987, 415(2), 323-330.

[318] Jacobson, K.A.; von Lubitz, D.K.; Daly, J.W.; Fredholm, B.B. Adenosine receptor ligands: differences with acute versus chronic treatment. Trends Pharmacol. Sci., 1996, 17(3), 108-113.

[319] Samsel, M.; Dzierzbicka, K. Therapeutic potential of adenosine analogues and conjugates. Pharmacol. Rep., 2011, 63(3), 601-617.

[320] Gomtsyan, A.; Didomenico, S.; Lee, C.H.; Stewart, A.O.; Bhagwat, S.S.; Kowaluk, E.A.; Jarvis, M.F. Synthesis and biological evaluation of pteridine and pyrazolopyrimidine based adenosine kinase inhibitors. Bioorg. Med. Chem. Lett., 2004, 14(16), 4165-4168.

[321] Perner, R.J.; Lee, C.H.; Jiang, M.; Gu, Y.G.; Didomenico, S.; Bayburt, E.K.; Alexander, K.M.; Kohlhaas, K.L.; Jarvis, M.F.; Kowaluk, E.L.; Bhagwat, S.S. Synthesis and biological evaluation of 6,7-disubstituted 4-aminopyrido[2,3-d]pyrimidines as adenosine kinase inhibitors. Bioorg. Med. Chem. Lett., 2005, 15(11), 28032807. 
[322] Kowaluk, E.A.; Mikusa, J.; Wismer, C.T.; Zhu, C.Z.; Schweitzer, E.; Lynch, J.J.; Lee, C.H.; Jiang, M.; Bhagwat, S.S.; Gomtsyan, A.; McKie, J.; Cox, B.F.; Polakowski, J.; Reinhart, G.; Williams, M.; Jarvis, M.F. ABT-702 (4-amino-5-(3-bromophenyl)-7-(6morpholino-pyridin- 3-yl)pyrido[2,3-d]pyrimidine), a novel orally effective adenosine kinase inhibitor with analgesic and antiinflammatory properties. II. In vivo characterization in the rat. $J$. Pharmacol. Exp. Ther., 2000, 295(3), 1165-1174.

[323] Matulenko, M.A.; Paight, E.S.; Frey, R.R.; Gomtsyan, A.; DiDomenico, S., Jr.; Jiang, M.; Lee, C.H.; Stewart, A.O.; Yu, H.; Kohlhaas, K.L.; Alexander, K.M.; McGaraughty, S.; Mikusa, J.; Marsh, K.C.; Muchmore, S.W.; Jakob, C.L.; Kowaluk, E.A.; Jarvis, M.F.; Bhagwat, S.S. 4-amino-5-aryl-6-arylethynylpyrimidines: Structureactivity relationships of non-nucleoside adenosine kinase inhibitors. Bioorg. Med. Chem., 2007, 15(4), 1586-1605.

[324] Wang, Z.; Quiocho, F.A. Complexes of adenosine deaminase with two potent inhibitors: X-ray structures in four independent molecules at $\mathrm{pH}$ of maximum activity. Biochemistry, 1998, 37(23), 8314-8324.

[325] Reayi, A.; Hosmane, R.S. Inhibition of adenosine deaminase by novel 5:7 fused heterocycles containing the imidazo[4,5e] $[1,2,4]$ triazepine ring system: A structure-activity relationship study. J. Med. Chem., 2004, 47(4), 1044-1050.

[326] Da Settimo, F.; Primofiore, G.; La Motta, C.; Taliani, S.; Simorini, F.; Marini, A.M.; Mugnaini, L.; Lavecchia, A.; Novellino, E.; Tuscano, D.; Martini, C. Novel, highly potent adenosine deaminase inhibitors containing the pyrazolo[3,4-d]pyrimidine ring system. Synthesis, structure-activity relationships, and molecular modeling studies. J. Med. Chem., 2005, 48(16), 5162-5174.

[327] Terasaka, T.; Okumura, H.; Tsuji, K.; Kato, T.; Nakanishi, I.; Kinoshita, T.; Kato, Y.; Kuno, M.; Seki, N.; Naoe, Y.; Inoue, T.; Tanaka, K.; Nakamura, K. Structure-based design and synthesis of non-nucleoside, potent, and orally bioavailable adenosine deaminase inhibitors. J. Med. Chem., 2004, 47(11), 2728-2731.

[328] Lee, K.M.; Choi, W.J.; Lee, Y.; Lee, H.J.; Zhao, L.X.; Lee, H.W.; Park, J.G.; Kim, H.O.; Hwang, K.Y.; Heo, Y.S.; Choi, S.; Jeong, L.S. X-ray crystal structure and binding mode analysis of human sadenosylhomocysteine hydrolase complexed with novel mechanism-based inhibitors, haloneplanocin A analogues. J. Med. Chem., 2011, 54(4), 930-938

[329] Kim, B.G.; Chun, T.G.; Lee, H.Y.; Snapper, M.L. A new structural class of s-adenosylhomocysteine hydrolase inhibitors. Bioorg. Med. Chem., 2009, 17(18), 6707-6714.

[330] Choi, J.S.; Berdis, A.J. Nucleoside transporters: Biological insights and therapeutic applications. Future Med. Chem., 2012, 4(11), 1461-1478.

[331] Tromp, R.A.; Spanjersberg, R.F.; von Frijtag Drabbe Kunzel, J.K.; AP, I.J. Inhibition of nucleoside transport proteins by C8alkylamine-substituted purines. J. Med. Chem., 2005, 48(1), 321329.

[332] Zhu, Z.; Furr, J.; Buolamwini, J.K. Synthesis and flow cytometric evaluation of novel 1,2,3,4-tetrahydroisoquinoline conformationally constrained analogues of nitrobenzylmercaptopurine riboside (NBMPR) designed for probing its conformation when bound to the es nucleoside transporter. J. Med. Chem., 2003, 46(5), 831-837.

[333] Zhu, Z.; Buolamwini, J.K. Constrained nbmpr analogue synthesis, pharmacophore mapping and 3D-QSAR modeling of equilibrative nucleoside transporter 1 (ENT1) inhibitory activity. Bioorg. Med. Chem., 2008, 16(7), 3848-3865.

[334] Lin, W.; Buolamwini, J.K. Design, synthesis, and evaluation of 2diethanolamino-4,8-diheptamethyleneimino-2-(N-aminoethyl-Nethanolamino)-6-(N,N-diethanolamino)pyrimido[5,4-d]pyrimidinefluorescein conjugate (8MDP-fluor), as a novel equilibrative nucleoside transporter probe. Bioconjug. Chem., 2011, 22(6), 12211227.

[335] Chang, C.; Swaan, P.W.; Ngo, L.Y.; Lum, P.Y.; Patil, S.D.; Unadkat, J.D. Molecular requirements of the human nucleoside transporters hCNT1, hCNT2, and hENT1. Mol. Pharmacol., 2004, 65(3), 558-570.

[336] Ritzel, M.W.; Ng, A.M.; Yao, S.Y.; Graham, K.; Loewen, S.K.; Smith, K.M.; Hyde, R.J.; Karpinski, E.; Cass, C.E.; Baldwin, S.A.; Young, J.D. Recent molecular advances in studies of the concentrative $\mathrm{Na}+$-dependent nucleoside transporter (CNT) family: Identification and characterization of novel human and mouse proteins (hCNT3 and mCNT3) broadly selective for purine and pyrimidine nucleosides (system cib). Mol. Membr. Biol., 2001, 18(1), 65-72.
[337] Wang, C.; Pimple, S.; Buolamwini, J.K. Interaction of benzopyranone derivatives and related compounds with human concentrative nucleoside transporters 1,2 and 3 heterologously expressed in porcine PK15 nucleoside transporter deficient cells. Structure-activity relationships and determinants of transporter affinity and selectivity. Biochem. Pharmacol., 2010, 79(3), 307-320.

[338] Tatani, K.N.I.; Kikuchi, N. Preparation of purine nucleoside derivatives modified in 8-position as inhibitors of concentrative nucleoside transporters 2. WO2006/030803, 2006.

[339] Verzijl, D.; Ijzerman, A.P. Functional selectivity of adenosine receptor ligands. Purinergic Signal., 2011, 7(2), 171-192.

[340] Stone, T.W.; Ceruti, S.; Abbracchio, M.P. Adenosine receptors and neurological disease: Neuroprotection and neurodegeneration. Handb. Exp. Pharmacol., 2009, 193, 535-587.

[341] Muller, C.E.; Jacobson, K.A. Recent developments in adenosine receptor ligands and their potential as novel drugs. Biochim. Biophys. Acta, 2011, 1808(5), 1290-1308.

[342] Klaasse, E.C.; Ijzerman, A.P.; de Grip, W.J.; Beukers, M.W. Internalization and desensitization of adenosine receptors. Purinergic Signal., 2008, 4(1), 21-37.

[343] Kiesman, W.F.; Elzein, E.; Zablocki, J. A1 adenosine receptor antagonists, agonists, and allosteric enhancers. Handb. Exp. Pharmacol., 2009, 193, 25-58.

[344] Romagnoli, R.; Baraldi, P.G.; Carrion, M.D.; Cara, C.L.; CruzLopez, O.; Salvador, M.K.; Preti, D.; Tabrizi, M.A.; Shryock, J.C.; Moorman, A.R.; Vincenzi, F.; Varani, K.; Borea, P.A. Structureactivity relationships of 2-amino-3-aroyl-4-[(4-arylpiperazin-1yl)methyl]thiophenes. Part 2: Probing the influence of diverse substituents at the phenyl of the arylpiperazine moiety on allosteric enhancer activity at the A(1) adenosine receptor. Bioorg. Med. Chem., 2012, 20(2), 996-1007.

[345] Clementina, M.; Giuseppe, S. A2a receptor ligands: Past, present and future trends. Curr. Top. Med. Chem., 2010, 10(9), 902-922.

[346] Ortore, G.; Martinelli, A. A2b receptor ligands: Past, present and future trends. Curr. Top. Med. Chem., 2010, 10(9), 923-940.

[347] Volpini, R.; Buccioni, M.; Dal Ben, D.; Lambertucci, C.; Lammi, C.; Marucci, G.; Ramadori, A.T.; Klotz, K.N.; Cristalli, G. Synthesis and biological evaluation of 2-alkynyl-N6-methyl-5'-Nmethylcarboxamidoadenosine derivatives as potent and highly selective agonists for the human adenosine A3 receptor. J. Med. Chem., 2009, 52(23), 7897-7900.

[348] Norstrand, I.F.; Glantz, M.D. Topographical distribution of purine nucleoside phosphorylase in the human neuraxis. Enzyme, 1980, 25(2), 118-122.

[349] Dawson, D.M. Absence of guanine deaminase from cerebellum. Neurology, 1971, 21(6), 621-626.

[350] Dwivedi, C.; Harbison, R.D. Anticonvulsant activities of delta-8 and delta-9 tetrahydrocannabinol and uridine. Toxicol. Appl. Pharmacol., 1975, 31(3), 452-458.

[351] Roberts, C.A. Anticonvulsant effects of uridine: comparative analysis of metrazol and penicillin induced foci. Brain Res., 1973, 55(2), 291-308.

[352] Roberts, C.A.; Kreisman, N.R.; Waltman, M. Uridine anticonvulsant effects: selective control of nucleoside incorporation in experimental epilepsy. Epilepsia, 1974, 15(4), 479-500.

[353] Piccoli, F.; Camarda, R.; Bonavita, V. The brain nucleotide pattern of the rat after injection of uracil, uridine and uridine phosphate. Acta Neurol. (Napoli), 1971, 26(1), 109-117.

[354] Guarneri, P.; Guarneri, R.; La Bella, V.; Piccoli, F. Interaction between uridine and GABA-mediated inhibitory transmission studies in vivo and in vitro. Epilepsia, 1985, 26(6), 666-671.

[355] Kardos, J.; Kovács, I.; Szárics, É.; Kovács, R.; Skuban, N.; Nyitrai, G.; Dobolyi, Á.; Juhász, G. Uridine activates fast transmembrane $\mathrm{Ca} 2+$ ion fluxes in rat brain homogenates. Neuroreport, 1999, 10(7), 1577-1582.

[356] Kimura, T.; Miki, M.; Ikeda, M.; Yonemoto, S.; Watanabe, K. Kondo, S.; Ho, I.K.; Yamamoto, I. Possible existence of a novel receptor for uridine analogues in the central nervous system using two isomers, N3-(S)-(+)- and N3-(R)-(-)-alpha-hydroxy-betaphenethyluridines. Biol. Pharm. Bull., 2001, 24(6), 729-731.

[357] Richardson, U.I.; Watkins, C.J.; Pierre, C.; Ulus, I.H.; Wurtman, R.J. Stimulation of CDP-choline synthesis by uridine or cytidine in PC12 rat pheochromocytoma cells. Brain Res., 2003, 971(2), 161167.

[358] Brunschweiger, A.; Muller, C.E. P2 receptors activated by uracil nucleotides-an update. Curr. Med. Chem., 2006, 13(3), 289-312. 
[359] Yegutkin, G.G. Nucleotide- and nucleoside converting ectoenzymes: important modulators of purinergic signalling cascade. Biochim. Biophys. Acta, 2008, 1783(5), 673-694.

[360] Van Groeningen, C.J.; Peters, G.J.; Nadal, J.C.; Laurensse, E.; Pinedo, H.M. Clinical and pharmacologic study of orally administered uridine. J. Natl. Cancer Inst., 1991, 83(6), 437-441.

[361] Van Groeningen, C.J.; Peters, G.J.; Pinedo, H.M. Modulation of fluorouracil toxicity with uridine. Semin. Oncol., 1992, 19(2 Suppl 3), 148-154

[362] Van Groeningen, C.J.; Peters, G.J.; Pinedo, H.M. Reversal of 5fluorouracil-induced toxicity by oral administration of uridine. Ann. Oncol., 1993, 4(4), 317-320.

[363] Page, T.; Yu, A.; Fontanesi, J.; Nyhan, W.L. Developmental disorder associated with increased cellular nucleotidase activity. Proc. Natl. Acad. Sci. U.S.A., 1997, 94(21), 11601-11606.

[364] Connolly, G.P.; Duley, J.A. Uridine and its nucleotides: biological actions, therapeutic potentials. Trends Pharmacol. Sci., 1999, 20(5), 218-225.

[365] Bonavita, V.; Piccoli, F.; Savettieri, G.; Zito, M. Observations on the therapeutic usefulness of uridine in epilepsy. Acta Neurol. ( $\mathrm{Na}$ poli), 1975, 30(1), 30-34.

[366] Cansev, M.; Marzloff, G.; Sakamoto, T.; Ulus, I.H.; Wurtman, R.J. Giving uridine and/or docosahexaenoic acid orally to rat dams during gestation and nursing increases synaptic elements in brains of weanling pups. Dev. Neurosci., 2009, 31(3), 181-192.

[367] Wurtman, R.J. Synapse formation and cognitive brain development: effect of docosahexaenoic acid and other dietary constituents. Metabolism, 2008, 57(Suppl 2), S6-10.

[368] Schmidt, A.P.; Avila, T.T.; Souza, D.O. Intracerebroventricular guanine-based purines protect against seizures induced by quinolinic acid in mice. Neurochem. Res., 2005, 30(1), 69-73.

[369] Schmidt, A.P.; Lara, D.R.; Souza, D.O. Proposal of a guaninebased purinergic system in the mammalian central nervous system. Pharmacol. Ther., 2007, 116(3), 401-416.

[370] Schmidt, A.P.; Tort, A.B.; Souza, D.O.; Lara, D.R. Guanosine and its modulatory effects on the glutamatergic system. Eur. Neuropsychopharmacol., 2008, 18(8), 620-622.

[371] Vinadé, E.R.; Schmidt, A.P.; Frizzo, M.E.; Izquierdo, I.; Elisabetsky, E.; Souza, D.O. Chronically administered guanosine is anticonvulsant, amnesic and anxiolytic in mice. Brain Res., 2003, 977(1), 97-102.

[372] Oses, J.P.; Leke, R.; Portela, L.V.; Lara, D.R.; Schmidt, A.P.; Casali, E.A.; Wofchuk, S.; Souza, D.O.; Sarkis, J.J. Biochemical brain markers and purinergic parameters in rat CSF after seizure induced by pentylenetetrazol. Brain Res. Bull., 2004, 64(3), 237242.

[373] Tavares, R.G.; Schmidt, A.P.; Abud, J.; Tasca, C.I.; Souza, D.O. In vivo quinolinic acid increases synaptosomal glutamate release in rats: reversal by guanosine. Neurochem. Res., 2005, 30(4), 439444.

[374] Tavares, R.G.; Schmidt, A.P.; Tasca, C.I.; Souza, D.O. Quinolinic acid-induced seizures stimulate glutamate uptake into synaptic vesicles from rat brain: effects prevented by guanine-based purines. Neurochem. Res., 2008, 33(1), 97-102.

[375] Soares, F.A.; Schmidt, A.P.; Farina, M.; Frizzo, M.E.S.; Tavares, R.G.; Portela, L.V.C.; Lara, D.R.; Souza, D.O. Anticonvulsant effect of GMP depends on its conversion to guanosine. Brain Res., 2004, $1005(1-2), 182-186$.

[376] Torres, F.V.; da Silva Filho, M.; Antunes, C.; Kalinine, E.; Antoniolli, E.; Portela, L.V.; Souza, D.O.; Tort. A.B. Electrophysiological effects of guanosine and MK-801 in a quinolinic acid-induced seizure model. Exp. Neurol., 2010, 221(2), 296-306.

[377] Vinadé, E.R.; Schmidt, A.P.; Frizzo, M.E.; Portela, L.V.; Soares, F.A.; Schwalm, F.D.; Elisabetsky, E.; Izquierdo, I.; Souza, D.O. Effects of chronic administered guanosine on behavioral parameters and brain glutamate uptake in rats. J. Neurosci. Res., 2005, 79(1-2), 248-253.

[378] Frizzo, M.E.; Schwalm, F.D.; Frizzo, J.K.; Soares, F.A.; Souza, D.O. Guanosine enhances glutamate transport capacity in brain cortical slices. Cell. Mol. Neurobiol., 2005, 25(5), 913-921.

[379] Ciccarelli, R.; Di Iorio, P.; D'Alimonte, I.; Giuliani, P.; Florio, T.; Caciagli, F.; Middlemiss, P.J.; Rathbone, M.P. Cultured astrocyte proliferation induced by extracellular guanosine involves endogenous adenosine and is raised by the co-presence of microglia. Glia, 2000, 29(3), 202-211.
[380] Rathbone, M.P.; Middlemiss, P.J.; DeLuca, B.; Jovetich, M. Extracellular guanosine increases astrocyte cAMP: inhibition by adenosine A2 antagonists. Neuroreport, 1991, 2(11), 661-664.

[381] Rathbone, M.; Pilutti, L.; Caciagli, F.; Jiang, S. Neurotrophic effects of extracellular guanosine. Nucleosides Nucleotides Nucleic Acids, 2008, 27(6), 666-672.

[382] Ates, N.; Sahin, D.; Ilbay, G. Theophylline, a methylxanthine derivative, suppresses absence epileptic seizures in WAG/Rij rats. Epilepsy Behav., 2004, 5(5), 645-648.

[383] Schmidt, A.P.; Böhmer, A.E.; Leke, R.; Schallenberger, C.; Antunes, C.; Pereira, M.S.; Wofchuk, S.T.; Elisabetsky, E.; Souza, D.O. Antinociceptive effects of intracerebroventricular administration of guanine-based purines in mice: evidences for the mechanism of action. Brain Res., 2008, 1234, 50-58.

[384] Schmidt, A.P.; Paniz, L.; Schallenberger, C.; Böhmer, A.E.; Wofchuk, S.T.; Elisabetsky, E.; Portela, L.V.; Souza, D.O. Guanosine prevents thermal hyperalgesia in a rat model of peripheral mononeuropathy. J. Pain., 2010, 11(2), 131-141.

[385] Berman, R.F.; Fredholm, B.B.; Aden, U.; O'Connor, W.T. Evidence for increased dorsal hippocampal adenosine release and metabolism during pharmacologically induced seizures in rats. Brain Res., 2000, 872(1-2), 44-53.

[386] Lewin, E.; Bleck, V. Electroshock seizures in mice: effect on brain adenosine and its metabolites. Epilepsia, 1981, 22(5), 577-581.

[387] Lewin, E.; Bleck, V. Electroshock raises pentylenetetrazol threshold: possible role of inosine. Life Sci., 1983, 32(5), 433-436.

[388] Winn, H.R.; Welsh, J.E.; Rubio, R.; Berne, R.M. Changes in brain adenosine during bicuculline-induced seizures in rats. Effects of hypoxia and altered systemic blood pressure. Circ. Res., 1980, 47(4), 568-577.

[389] Pull, I.; McIlwain, H. Metabolism of (14 C)adenine and derivatives by cerebral tissues, superfused and electrically stimulated. Biochem. J., 1972, 126(4), 965-973.

[390] Skolnick, P.; Syapin, P.J.; Paugh, B.A.; Moncada, V.; Marangos, P.J.; Paul, S.M. Inosine, an endogenous ligand of the brain benzodiazepine receptor, antagonizes pentylenetetrazole-evoked seizures. Proc. Natl. Acad. Sci. U.S.A., 1979, 76(3), 1515-1518.

[391] Marangos, P.J.; Martino, A.M.; Paul, S.M.; Skolnick, P. The benzodiazepines and inosine antagonize caffeine-induced seizures. Psychopharmacology (Berl.), 1981, 72(3), 269-273.

[392] Ganzella, M.; Faraco, R.B.; Almeida, R.F.; Fernandes, V.F.; Souza, D.O. Intracerebroventricular administration of inosine is anticonvulsant against quinolinic acid-induced seizures in mice: an effect independent of benzodiazepine and adenosine receptors. Pharmacol. Biochem. Behav., 2011, 100(2), 271-274.

[393] Di Iorio, P.; Virgilio, A.; Giuliani, P.; Ballerini, P.; Vianale, G.; Middlemiss, P.J.; Rathbone, M.P.; Ciccarelli, R. AIT-082 is neuroprotective against kainate-induced neuronal injury in rats. Exp. Neurol., 2001, 169(2), 392-399.

[394] Subrahmanyam, K.; Murthy, B.; Prasad, M.S.; Shrivastaw, K.P.; Sadasivudu, B. Adenosine deaminase in convulsions along with its regional, cellular and synaptosomal distribution in rat brain. Neurosci. Lett., 1984, 48(3), 327-331.

[395] Asano, T.; Spector, S. Identification of inosine and hypoxanthine as endogenous ligands for the brain benzodiazepine-binding sites. Proc. Natl. Acad. Sci. U.S.A., 1979, 76(2), 977-981.

[396] Skolnick, P.; Marangos, P.J.; Syapin, P.; Goodwin, F.K.; Paul, S.M. CNS benzodiazepine receptors: physiological studies and putative endogenous ligands. Pharmacol. Biochem. Behav., 1979, 10(5), 815-823.

[397] Skolnick, P.; Paul, S.M.; Marangos, P.J. Purines as endogenous ligands of the benzodiazepine receptor. Fed. Proc., 1980, 39(12), 3050-3055.

[398] MacDonald, J.F.; Barker, J.L.; Paul, S.M.; Marangos, P.J.; Skolnick, P. Inosine may be an endogenous ligand for benzodiazepine receptors on cultured spinal neurons. Science, 1979, 205(4407), 715-717.

[399] Paul, S.M.; Marangos, P.J.; Goodwin, F.K.; Skolnick, P. Brainspecific benzodiazepine receptors and putative endogenous benzodiazepine-like compounds. Biol. Psychiatry., 1980, 15(3), 407-428.

[400] Olsen, R.W.; Leeb-Lundberg, F. Endogenous inhibitors of picrotoxinin-convulsant binding sites in rat brain. Eur. J. Pharmacol., 1980, 65(1), 101-104.

[401] McKernan, R.M.; Whiting, P.J. Which GABAA-receptor subtypes really occur in the brain? Trends Neurosci., 1996, 19(4), 139-143. 
[402] Marangos, P.J.; Trams, E.; Clark-Rosenberg, R.L.; Paul, S.M.; Skolnick, P. Anticonvulsant doses of inosine result in brain levels sufficient to inhibit $[3 \mathrm{H}]$ diazepam binding. Psychopharmacology (Berl.), 1981, 75(2), 175-178.

[403] Haskó, G.; Sitkovsky, M.V.; Szabó, Cs. Immunomodulatory and neuroprotective effects of inosine. Trends Pharmacol. Sci., 2004, 25(3), 152-157.

[404] Van Dycke, A.; Raedt, R.; Vonck, K.; Boon, P. Local delivery strategies in epilepsy: a focus on adenosine. Seizure, 2011, 20(5), 376-382

[405] Horan, R.L.; Antle, K.; Collette, A.L.; Wang, Y.; Huang, J.; Moreau, J.E.; Volloch, V.; Kaplan, D.L.; Altman, G.H. In vitro degradation of silk fibroin. Biomaterials, 2005, 26(17), 3385-3393.

[406] Pritchard, E.M.; Szybala, C.; Boison, D.; Kaplan, D.L. Silk fibroin encapsulated powder reservoirs for sustained release of adenosine. J. Control. Release, 2010, 144(2), 159-167.

[407] Wilz, A.; Pritchard, E.M.; Li, T.; Lan, J.Q.; Kaplan, D.L.; Boison, D. Silk polymer-based adenosine release: therapeutic potential for epilepsy. Biomaterials, 2008, 29(26), 3609-3616.

[408] Szybala, C.; Pritchard, E.M.; Lusardi, T.A.; Li, T.; Wilz, A.; Kaplan, D.L.; Boison, D. Antiepileptic effects of silk-polymer based adenosine release in kindled rats. Exp. Neurol., 2009, 219(1), 126-135.

[409] McCown, T.J. The future of epilepsy treatment: focus on adenoassociated virus vector gene therapy. Drug News Perspect., 2010, 23(5), 281-286.

[410] Li, T.; Ren, G.; Kaplan, D.L.; Boison, D. Human mesenchymal stem cell grafts engineered to release adenosine reduce chronic seizures in a mouse model of CA3-selective epileptogenesis. Epilepsy Res., 2009, 84(2-3), 238-241.

[411] Ren, G.; Li, T.; Lan, J.Q.; Wilz, A.; Simon, R.P.; Boison, D. Lentiviral RNAi-induced downregulation of adenosine kinase in human mesenchymal stem cell grafts: a novel perspective for seizure control. Exp. Neurol., 2007, 208(1), 26-37.

[412] Ren, G.; Boison, D. Engineering human mesenchymal stem cells to release adenosine using miRNA technology. Methods Mol. Biol., 2010, 650, 225-240.

[413] Boison, D. Inhibitory RNA in epilepsy: research tools and therapeutic perspectives. Epilepsia, 2010, 51(9), 1659-1668.

[414] Theofilas, P.; Brar, S.; Stewart, K.A.; Shen, H.Y.; Sandau, U.S.; Poulsen, D.; Boison, D. Adenosine kinase as a target for therapeutic antisense strategies in epilepsy. Epilepsia, 2011, 52(3), 589-601.

[415] Weinberg, M.S.; McCown, T.J. Current prospects and challenges for epilepsy gene therapy. Exp. Neurol., 2013, 244, 27-35.

[416] Boison, D. Adenosine-based cell therapy approaches for pharmacoresistant epilepsies. Neurodegener. Dis., 2007, 4(1), 28-33.
[417] Boison, D.; Huber, A.; Padrun, V.; Déglon, N.; Aebischer, P.; Möhler, H. Seizure suppression by adenosine-releasing cells is independent of seizure frequency. Epilepsia, 2002, 43(8), 788-796.

[418] Boison, D. Cell and gene therapies for refractory epilepsy. Curr. Neuropharmacol., 2007, 5(2), 115-125.

[419] Güttinger, M.; Padrun, V.; Pralong, W.F.; Boison, D. Seizure suppression and lack of adenosine A1 receptor desensitization after focal long-term delivery of adenosine by encapsulated myoblasts. Exp. Neurol., 2005, 193(1), 53-64.

[420] Güttinger, M.; Fedele, D.; Koch, P.; Padrun, V.; Pralong, W.F.; Brüstle, O.; Boison, D. Suppression of kindled seizures by paracrine adenosine release from stem cell-derived brain implants. Epilepsia, 2005, 46(8), 1162-1169.

[421] Fedele, D.E.; Koch, P.; Scheurer, L.; Simpson, E.M.; Möhler, H.; Brüstle, O.; Boison, D. Engineering embryonic stem cell derived glia for adenosine delivery. Neurosci. Lett., 2004, 370(2-3), 160165.

[422] Li, T.; Steinbeck, J.A.; Lusardi, T.; Koch, P.; Lan, J.Q.; Wilz, A.; Segschneider, M.; Simon, R.P.; Brüstle, O.; Boison, D. Suppression of kindling epileptogenesis by adenosine releasing stem cellderived brain implants. Brain, 2007, 130(Pt 5), 1276-1288.

[423] O'Brien, D.R. The adenosine hypothesis of epilepsy. Med. Hy potheses, 1988, 27(4), 281-284.

[424] Da Rocha Lapa, F.; Da Silva, M.D.; De Almeida Cabrini, D.; Santos, A.R. Anti-inflammatory effects of purine nucleosides, adenosine and inosine, in a mouse model of pleurisy: evidence for the role of adenosine A(2) receptors. Purinergic Signal., 2012, 8(4), 693-704

[425] Evaldsson, C.; Rydén, I.; Uppugunduri, S. Anti-inflammatory effects of exogenous uridine in an animal model of lung inflammation. Int. Immunopharmacol., 2007, 7(8), 1025-1032.

[426] Haskó, G.; Kuhel, D.G.; Németh, Z.H.; Mabley, J.G.; Stachlewitz, R.F.; Virág, L.; Lohinai, Zs.; Southan, G.J.; Salzman, A.L.; Szabó, C. Inosine inhibits inflammatory cytokine production by a posttranscriptional mechanism and protects against endotoxin-induced shock. J. Immunol., 2000, 164(2), 1013-1019.

[427] Volonté, C.; D'Ambrosi, N. Membrane compartments and purinergic signalling: the purinome, a complex interplay among ligands, degrading enzymes, receptors and transporters. FEBS J., 2009, 276(2), 318-329.

[428] Borowicz, K.K.; Swiader, M.; Wielosz, M.; Czuczwar, S.J. Influence of the combined treatment of LY 300164 (an AMPA/kainate receptor antagonist) with adenosine receptor agonists on the electroconvulsive threshold in mice. Eur. Neuropsychopharmacol., 2004, 14(5), 407-412. 